Andrews University

Digital Commons @ Andrews University

\title{
A Program To Improve Bible Study and Prayer in the Humboldt Park Hispanic Seventh-day Adventist Church
}

Julio I. Juarez

Andrews University

Follow this and additional works at: https://digitalcommons.andrews.edu/dmin

Part of the Practical Theology Commons

\section{Recommended Citation}

Juarez, Julio I., "A Program To Improve Bible Study and Prayer in the Humboldt Park Hispanic Seventh-day Adventist Church" (2001). Professional Dissertations DMin. 564.

https://dx.doi.org/10.32597/dmin/564

https://digitalcommons.andrews.edu/dmin/564

This Project Report is brought to you for free and open access by the Graduate Research at Digital Commons @ Andrews University. It has been accepted for inclusion in Professional Dissertations DMin by an authorized administrator of Digital Commons @ Andrews University. For more information, please contact repository@andrews.edu. 


\section{ABSTRACT}

\section{A PROGRAM TO IMPROVE BIBLE STUDY AND PRAYER IN THE HUMBOLDT PARK HISPANIC SEVENTH-DAY ADVENTIST CHURCH}

by

Julio I. Juárez

Adviser: Ricardo Norton 


\section{ABSTRACT OF GRADUATE STUDENT RESEARCH}

Dissertation

Andrews University

Seventh-day Adventist Theological Seminary

Title: A PROGRAM TO IMPROVE BIBLE STUDY AND PRAYER IN THE HUMBOLDT PARK SEVENTH-DAY ADVENTIST HISPANIC CHURCH

Name of researcher: Julio I. Juárez

Name and degree of faculty adviser: Ricardo Norton, D.Min.

Date completed: August 2001

\section{Problem}

A survey conducted in the Humboldt Park Hispanic SDA church (HPHC)

indicated that its members, like many others in our post-modern society, have neglected personal Bible study (PBS) and prayer. The results of this were evident in many aspects of their lives.

\section{Method}

This problem was brought to the attention of church leaders (elders and the church board). Consequently, a strategy was developed for involving all members in a week of prayer and seminars centered around personal Bible study and prayer. The seminars 
were based on a review of related literature. A survey was conducted before and after the project to highlight members' changes in attitudes and behavior in these two areas. Several aspects of members' participation were also observed and recorded as a measure of change.

\author{
Results
}

Approximately 80 of 130 members participated in the week of prayer and seminars. After the project, members who participated felt that personal Bible study and prayer were more important and indicated that they engaged in these activities more frequently than before. The church's attendance, tithes, participation, and outreach activity also increased.

\title{
Conclusions
}

The Bible and other Christian literature indicate that personal Bible study and prayer are key to spiritual growth. This was also found to be true in the HPHC. A focus on PBS and prayer resulted in positive change in many areas of members' spiritual lives. 


\title{
Andrews University
}

Seventh-day Adventist Theological Seminary

\section{A PROGRAM TO IMPROVE BIBLE STUDY AND PRAYER IN THE HUMBOLDT PARK HISPANIC SEVENTH-DAY ADVENTIST CHURCH}

\author{
A Dissertation \\ Presented in Partial Fulfillment \\ of the Requirements for the Degree \\ Doctor of Ministry
}

by

Julio I. Juárez

August 2001 

A PROGRAM TO IMPROVE BIBLE STUDY AND PRAYER IN THE HUMBOLDT PARK HISPANIC SEVENTH-DAY ADVENTIST CHURCH

A dissertation

presented in partial fulfillment

of the requirements for the degree

Doctor of Ministry

by

Julio I. Juarez

APPROVAL BY THE COMMITTEE:

Pecans Purdue

Adviser,

Ricardo Norton
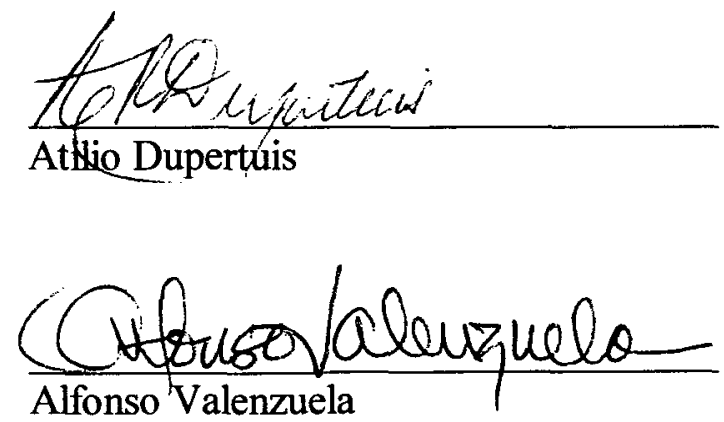
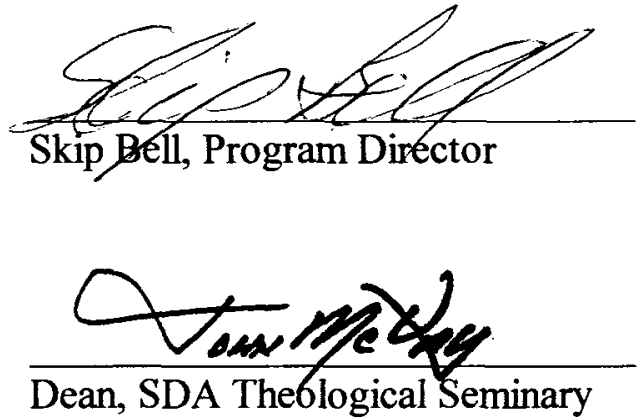

John McVay

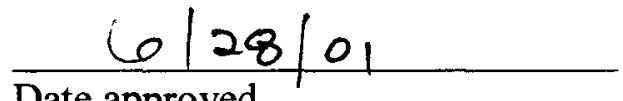

Date approved 
To my wife Antonia, my beautiful children Julio and Dayleen, and to my parents Adrian and Reginalda for the principles they taught me. 


\section{TABLE OF CONTENTS}

LIST OF ABBREVIATIONS $\ldots \ldots \ldots \ldots \ldots \ldots \ldots \ldots \ldots \ldots \ldots \ldots \ldots \ldots \ldots \ldots \ldots \ldots$

ACKNOWLEDGMENTS $\ldots \ldots \ldots \ldots \ldots \ldots \ldots \ldots \ldots \ldots \ldots \ldots \ldots \ldots$ viii

\section{Chapter}

I. INTRODUCTION $\ldots \ldots \ldots \ldots \ldots \ldots \ldots \ldots \ldots \ldots \ldots \ldots \ldots \ldots \ldots$

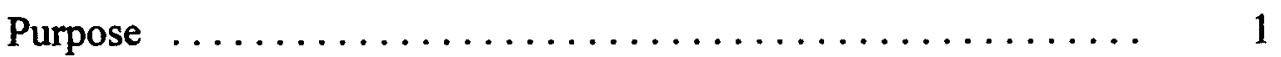

Justification $\ldots \ldots \ldots \ldots \ldots \ldots \ldots \ldots \ldots \ldots \ldots \ldots \ldots \ldots, 1$

Description of the Church $\ldots \ldots \ldots \ldots \ldots \ldots \ldots \ldots \ldots . .3$

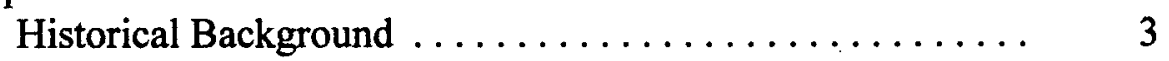

Neighborhood Environment ................. 5

Demographics ........................ 8

Limitations ............................. 10

Methodology ................................ 11

Overview of the Study $\ldots \ldots \ldots \ldots \ldots \ldots \ldots \ldots \ldots \ldots \ldots, 11$

II. BIBLICAL FOUNDATIONS $\ldots \ldots \ldots \ldots \ldots \ldots \ldots \ldots \ldots \ldots$

Biblical Insights on Prayer ...................... 13

Prayer in the OT $\ldots \ldots \ldots \ldots \ldots \ldots \ldots \ldots \ldots \ldots \ldots \ldots \ldots$

Hebrew Words for Prayer................. 14

OT Prayer Styles ..................... 23

Prayer in the NT ........................ 26

Greek Words for Prayer ................ 26

NT Prayer Styles ..................... 34

Biblical Insights on Personal Bible Study . . . . . . . . . . 37

Bible Study in the OT ...................... 38

Hebrew Words for Study $\ldots \ldots \ldots \ldots \ldots \ldots \ldots, \quad 38$

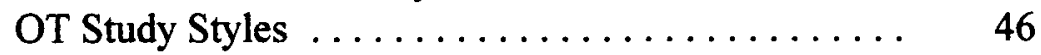

Bible Study in the NT $\ldots \ldots \ldots \ldots \ldots \ldots \ldots \ldots .49$

Greek Words for Study ................ 49

NT Bible Study Styles $\ldots \ldots \ldots \ldots \ldots \ldots \ldots \ldots, 55$

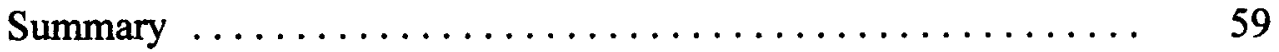


III. INSIGHTS ON PRAYER AND PBS FROM ELLEN WHITE AND CONTEMPORARY SCHOLARS .

Prayer ..................................... 61

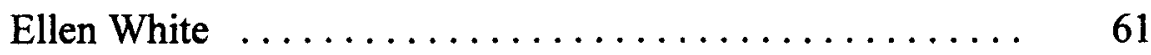

Contemporary Scholars $\ldots \ldots \ldots \ldots \ldots \ldots \ldots \ldots, 65$

Bible Study ................................. 67

Ellen White $\ldots \ldots \ldots \ldots \ldots \ldots \ldots \ldots \ldots \ldots, 67$

Contemporary Scholars $\ldots \ldots \ldots \ldots \ldots \ldots \ldots \ldots, 72$

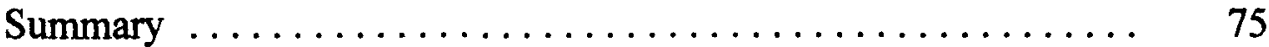

IV. DESIGNING A PRAYER AND PBS PROGRAM FOR THE HPHC 76

Post-Modern Society $\ldots \ldots \ldots \ldots \ldots \ldots \ldots \ldots \ldots \ldots \ldots \ldots$

Humboldt Park Church Members in Post-Modern Society .. $\quad 77$

Initial Steps to Address the Problem . ................ 78

Preliminary Survey $\ldots \ldots \ldots \ldots \ldots \ldots \ldots \ldots \ldots \ldots \ldots \ldots$

Involving the Church Elders $\ldots \ldots \ldots \ldots \ldots \ldots \ldots \ldots, 80$

Involving the Church Board Members ............ 82

Involving the Entire Congregation $\ldots \ldots \ldots \ldots \ldots \ldots \ldots, 85$

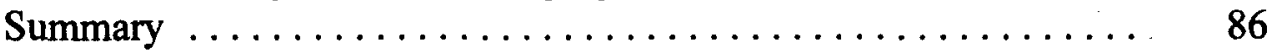

V. THE WEEK OF PRAYER AND THE SEMINARS $\ldots \ldots \ldots \ldots \ldots \quad 88$

The Week of Prayer ........................ 88

Before the Week of Prayer . . . . . . . . . . . . . $\quad 88$

During the Week of Prayer $\ldots \ldots \ldots \ldots \ldots \ldots \ldots \ldots, 91$

After the Week of Prayer $\ldots \ldots \ldots \ldots \ldots \ldots \ldots \ldots ., 94$

The Seminars ............................... 94

Summary $\ldots \ldots \ldots \ldots \ldots \ldots \ldots \ldots \ldots \ldots \ldots \ldots \ldots, 98$

VI. EVALUATION, CONCLUSION, AND RECOMMENDATIONS $\ldots 100$

Evaluation $\ldots \ldots \ldots \ldots \ldots \ldots \ldots \ldots \ldots \ldots \ldots \ldots \ldots \ldots \ldots \ldots$

Survey Administration ................... 102

Church Member Observation .................. 104

Conclusion ................................. 106

Recommendations ............................. 108

Appendix

A. HPHC MEMBERSHIP DATA, $1982-1998 \ldots \ldots \ldots \ldots \ldots \ldots \ldots, 110$

B. PRAYER AND PERSONAL BIBLE STUDY SURVEYS $\ldots \ldots \ldots \ldots 111$ 
C. SURVEY RESULTS (RAW DATA) ................. 114

D. OUTLINE OF WEEK OF PRAYER SERMONS $\ldots \ldots \ldots \ldots \ldots \ldots 117$

E. SEMINAR ADVERTISEMENTS AND MATERIALS $\ldots \ldots \ldots \ldots, 128$

F. PRACTICAL INSTRUCTIONS FOR PRAYER AND BIBLE STUDY 129

G. TRANSLATIONS OF HANDOUTS $\ldots \ldots \ldots \ldots \ldots \ldots \ldots \ldots, 140$

BIBLIOGRAPHY $\ldots \ldots \ldots \ldots \ldots \ldots \ldots \ldots \ldots \ldots \ldots \ldots \ldots \ldots \ldots \ldots \ldots \ldots \ldots \ldots$

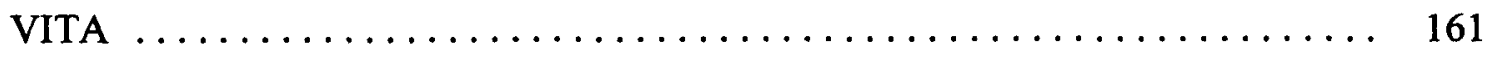




\section{LIST OF ABBREVIATIONS}

$\begin{array}{ll}\text { NIV } & \text { New International Version } \\ \text { HPHC } & \text { Humboldt Park Hispanic S.D.A. Church } \\ \text { PBS } & \text { Personal Bible Study } \\ \text { OT } & \text { Old Testament } \\ \text { NT } & \text { New Testament } \\ \text { EC } & \text { Early Church }\end{array}$




\section{ACKNOWLEDGMENTS}

I thank God for giving me life and time to finish this project. May all the glory be His. There are also several individuals who helped make the completion of this project possible, and I am extremely grateful to each of them.

First of all I want to thank my wife and children for putting up with me while writing this dissertation. Their nonstop support motivated me to keep going. My parents, despite their age, have always supported me with prayers as I pursued this program. Pastor Chanagá constantly encouraged me to complete this degree. My thanks also go to Dawnita Neal and Austin Baccus, my editors, for their time and dedication. And finally, this project would never have been the same without the valuable suggestions of my adviser, Dr. Ricardo Norton. 


\section{CHAPTER I}

\section{INTRODUCTION}

\section{Purpose}

The main goal of this project is to analyze the present spiritual condition of the Humboldt Park Hispanic Seventh-day Adventist Church (HPHC) regarding personal Bible study (PBS) and prayer, and to develop, implement, and evaluate a program to enhance these specific areas of spirituality among the members.

\section{Justification}

As members of the Hispanic minority population, members of the HPHC face the challenges of adjusting to the culture and city life of Chicago. Foster notes that living in a great metropolis requires people to change their lifestyles and adjust to noise, busyness, and crowds. ${ }^{1}$ Often the influence of post-modern trends can cause individuals to minimize the importance of their relationship with God. ${ }^{2}$ Jean F. Lyotard proposes that a church must break away from old patterns and begin a new way of spiritual living

${ }^{1}$ Richard Foster, Celebration of Discipline: The Path to Spiritual Growth (San Francisco: Harper Collins Division, 1978), 15.

${ }^{2}$ Meaghan Morris, "Things to Do with Shopping Centers," in The Cultural Studies Reader, ed. Simon During (New York: Routledge, 1993), 295. 
and thinking in order to avoid the dangers of post-modern society. ${ }^{1}$ This report focuses on ways to help members overcome the spiritual dangers of post-modern society through an emphasis on prayer and personal Bible study. A survey conducted in the church showed members were weak in those two areas of Christian life (see Appendix B).

Personal economic situations and the complexities of the Chicago environment have forced church members to pay little attention to these two important facets of their spiritual lives. Although the sanctuary is full every Saturday morning, very few attend the weekly prayer services on Wednesday and Friday evenings. This could be an indicator of minimal interest in spiritual growth. As this study shows, PBS and prayer are essential to spiritual growth, and members must become aware of this through an appropriate strategy in order to preserve and enhance their religious lives.

Because of the current lack of systematic instruction, it is imperative to develop a strategy for growth in these two vital aspects of spiritual life. If members could understand how important these facets are for their spiritual development, they would be more willing to make room for God in their lives and allow Him to permeate their inner selves. ${ }^{2}$ By leading each member to a closer walk with Jesus Christ through emphasis on prayer and personal study of the Bible, each participating individual can be spiritually rejuvenated, which can lead to a spiritual revival for the entire congregation.

'Jean F. Lyotard, "Defining the Postmodern," in The Cultural Studies Reader, ed. Simon During (New York: Routledge, 1993), 171.

${ }^{2}$ Phillip G. Samaan, Christ's Way to Spiritual Growth (Hagerstown, MD: Review and Herald Pub. Assn., 1995), 49. 


\section{Description of the Church}

A brief description of the church from its establishment to the present is necessary for this study. The historical background, neighborhood environment, and membership of this congregation are all factors which have affected its development. The following examination of these factors will help to explain the current need for spiritual growth through prayer and personal Bible study.

\section{Historical Background}

The best sources of information about the history are church members who were present at the time when the church was founded. Although the church and Illinois SDA Conference records contain some statistics about the HPHC's beginning and growth, the founding members' firsthand descriptions of the church's inception are the only resource for understanding the personal dynamics of the congregation's spiritual development. By interviewing some of the original members and pastors, I was able to obtain a unique perspective of its origins.

In the spring of 1982, Sergio Ortiz, an evangelist for the Illinois Conference of SDAs, decided to plant a new congregation on Chicago's northwest side. He chose a Hispanic area called Humboldt Park, ${ }^{1}$ whose inhabitants at the time were mainly from Puerto Rico.

${ }^{1}$ Sergio Ortiz, interview by author, August 2, 1997. 
In preparation for the first crusade in this area, five Bible workers offered Bible courses to the Hispanic neighborhood during a two-month period. ${ }^{1}$ That summer, Ortiz began an evangelistic crusade in a hall of the Army recruitment center in Humboldt Park. At its conclusion near the end of July 1982, thirty-seven new members joined the church through baptism. ${ }^{2}$ Immediately, the Illinois Conference of SDAs appointed Pastor Oliver Mastrapa to the new congregation. ${ }^{3}$

The new church faced a problem of leadership. Since all the members were recently baptized, none of them had the necessary experience to help Pastor Mastrapa to lead the new flock. They needed Sabbath school leaders, deacons, deaconesses, elders, and youth leaders. This necessity moved Pastor Funes and the church board of the Central Hispanic SDA Church to send ten leaders from their church to help the new church in these areas. ${ }^{4}$ The new leadership team set some objectives for the Humboldt Park congregation. Their goal was to train the new members for church administration, develop leadership talents among them, reinforce their faith, and teach them how to share the Good News with others. ${ }^{5}$

The nascent church also needed a meeting place. Since finances were quite limited at first, the new church members rented a Lutheran church in the Humboldt Park

${ }^{1}$ Ibid.

${ }^{2}$ Illinois Conference of SDAs, Baptisms, Updated Records, 1982.

${ }^{3}$ Illinois Conference of SDAs, Directory, 1983.

${ }^{4}$ Daisy Argueta, interview by author, 6 September 1997.

${ }^{5}$ Ibid. 
area in September of $1982 .^{1}$ After two years, they had to move again, renting a Pentecostal church in the same area. ${ }^{2}$ In 1989 , the congregation acquired their current building at $1733 \mathrm{~N}$. Kedvale in the La Hermosa community. ${ }^{3}$

\section{Neighborhood Environment}

Many sociological factors influence the community where the church is located. A brief description of its neighborhood will provide certain insights into the social dynamics which affect the church members.

The church building is currently located in northwest Chicago under the jurisdiction of the $31^{\text {st }}$ Ward. ${ }^{4}$ The population of this area represents a kaleidoscope of cultural groups such as Germans, Polish, Irish, and Hispanics. In the last ten years, the Latino population in this community has grown to be one half of the total population in

'Oliver Mastrapa, interview by author, 9 September 1997, Chicago. This church was located at Spaulding and Pierce streets on the north side of Chicago.

${ }^{2}$ Felipe Piñero, interview by author, 10 September 1997, Chicago. This church was located at Kedsy Avenue and Wabansia Street, still in the Humboldt Park area.

${ }^{3}$ Although HPHC is no longer located in the Humboldt Park area, the church still uses the name "Humboldt Park." The church's name is also listed as "Humboldt Park" in the records of the Illinois Conference of SDAs. Chicago.

${ }^{4}$ Alderman Rey Suárez, Chicago $31^{\text {st }}$ Ward, interview by author, 6 October 1997 , 
this section of Chicago. ${ }^{1}$ Two groups form the majority of the Hispanics in the HPHC area: Puerto Ricans and Mexicans. ${ }^{2}$

In this area, there are also seven elementary schools and one high school. The Humboldt Park elementary schools have been labeled "at risk" by the Chicago Board of Education because 63 percent of their students do not meet the scholastic requirements of the standardized math and science tests given by the Illinois Board of Education. ${ }^{3}$. According to Ronaldo Viber, a records worker in the Chicago Board of Education, 500 of the 1,800 Kelvin Park high-school students dropped out of school during the 19981999 school year, and this 28 percent dropout average is extremely high in comparison with the Chicago city-wide high-school dropout average number of 15.8 percent. ${ }^{4}$

According to the 1996 Illinois census report, the average family income of this community is $\$ 18,000$ a year. ${ }^{5}$ The average education level of the population is ninth grade, and neighborhood residents who have completed a graduate degree form a minority. Consequently, most people work in industry-related professions and earn minimum wages. ${ }^{6}$ Economic circumstances force parents to work for survival, a

${ }^{1}$ Fact Book Chicago Metropolitan Area 1990 (Chicago: Academy of Chicago Pub., 1995), 82-83.

${ }^{2}$ Suárez, interview.

${ }^{3}$ Fact Book, 83.

${ }^{4}$ Ronaldo Viber, telephone interview by author, 27 May 1999.

${ }^{5}$ The Source Book Zip Code, $13^{\text {th }}$ ed. (Omaha, NE: American Business Information, 1997), 74-A-B.

${ }^{6}$ Fact Book, 74. 
situation which often leaves children without supervision. In the $31^{\text {st }} \mathrm{Ward}$, many children and young people get involved in street activities including gangs and dealing drugs.

According to Alderman Rey Suárez of the $31^{\text {st }}$ Ward, some of the most frightening Hispanic gangs in Chicago operate in this section, including the "Latin Kings," the "Cobras," and the "Pachucos." Due to this situation, it is extremely dangerous to walk along certain streets at night. Gang symbols and graffiti marking the territories for specific gangs are common throughout this area.

Aida Vasquez, a long-time member of HPHC and resident of the area, comments that many drug dealers live in this area, ${ }^{2}$ and for that reason the crime rates in this district are very high. ${ }^{3}$ In spite of this perilous situation, no church member has ever suffered any personal harm from gangs or drug dealers in the streets around the church. At the present time, the walls and the physical structure of the church building have never been damaged by gang activity. ${ }^{4}$ Only about 10 percent of the congregation members live in the area surrounding the church, and these members are mostly elderly people fifty to sixty years old. These people are not targeted by gang members, who are most interested in the activities of people their age. Fortunately, the gang and drug

${ }^{1}$ Suárez, interview.

${ }^{2}$ Aida Vásquez, founding member, interview by author, 10 October, 1997.

${ }^{3}$ Suárez, interview.

${ }^{4}$ Lorenzo Ramírez, founding member, interview by author, 8 October, 1997. 
involvement of the neighborhood has not resulted in any mishap to church visitors or members.

\section{Demographics}

Due to the high Hispanic population where the church is located, the congregation tends to attract mainly Hispanic immigrants from foreign countries. These people are forced to move frequently because of economical problems and pressures from the immigration department. Some of them are undocumented. As a result, the present membership of this church changes constantly as members move on to other areas and new members come to take their place, as is indicated by the church's fluctuating membership (see Appendix A). Present church records show a membership of $134 .^{1}$ Few members have lived permanently in Chicago and its suburbs. Unquestionably, these members have given the congregation more stability. Only two of the original church-founding families still remain. ${ }^{2}$ Most of the original members have moved on to other churches in the North American Division, and the rest have been transferred to other Seventh-day Adventist divisions, including the Inter-American and South American Divisions.

\footnotetext{
'Secretary of the Illinois Conference of SDAs, Updated Membership Records, 1998.
}

${ }^{2}$ Ramón Quiñónez, interview by author, 5 October 1997 , Chicago. This member is one of the founders of HPHC. 
The membership represents a variety of Hispanic cultures, including members from South America, ${ }^{1}$ Central America, ${ }^{2}$ the Caribbean, ${ }^{3}$ and North America. ${ }^{4}$ This assortment of Hispanic members has enriched the internal environment of the church, because each member contributes with a diversity of experience and talents in the congregation.

Due to the low educational level of the members (very few church members have completed graduate degrees), ${ }^{5}$ their yearly income averages around $\$ 20,000$ per year. ${ }^{6}$ Only half of the congregation has finished high school. Thirty percent of the members are young people, between the ages of sixteen and twenty-two, some of whom have jobs or attend school. Two of the church families own small businesses, but 80 percent of the members work in manufacturing facilities or stores, receiving a minimum salary. The annual tithe sent by the church to the Illinois Conference has fluctuated over the past few years, but the last two years have shown an increase. In 1997, the tithe was

${ }^{1} H P H C$ Membership Book Record, $3^{\text {rd }}$ Quarter, 1997. The South American members come from Argentina, Ecuador, and Colombia.

${ }^{2}$ Ibid. The Central American members come from Guatemala, El Salvador, and Honduras.

${ }^{3} \mathrm{Ibid}$. The Caribbean members, which form a majority in the church, are from Puerto Rico and the Dominican Republic.

${ }^{4} \mathrm{Ibid}$. The North American members are from Mexico and the United States.

${ }^{5} H P H C$ Clerk Records, $4^{\text {th }}$ Quarter, 1997.

${ }^{6}$ HPHC Treasury Report, December 1997. 
$\$ 58,000$, and $\$ 64,000$ in $1998 .^{1}$ The annual local church offering was $\$ 15,200$ in 1997 , and $\$ 18,000$ in $1998 .^{2}$

In summary, this church is a fairly new church with unique dynamics due to its origins, location, and membership. Each of these factors influences the church and also affects the appropriate methodology and approach for improving the prayer and PBS styles of the congregation.

\section{Limitations}

This project is specifically designed to empower this particular congregation with the necessary tools for their spiritual growth in these two areas. Because of the focused design of this study, its conclusions and recommendations can be applied to this church only; however, since this project is based on general principles about prayer and PBS taken primarily from the Bible and Ellen White's writings, the program described throughout this dissertation could also be applied to other congregations that have similar characteristics.

The effects of this program on the participants were measured only during the time while the program was implemented. All surveys were given immediately before and after the program took place. Therefore, findings cannot be assumed to have continued after that time. Results are only applicable to the duration of the program.

'Illinois Conference of SDAs, Treasury Report, December 1997.

${ }^{2}$ HPHC Treasury Book Report, December 1997. 


\section{Methodology}

This project focuses on personal spirituality, which encompasses the entire Christian life. A special emphasis is made on PBS and prayer, two important aspects of spirituality. The biblical foundations are carefully examined in the light of passages from the Old Testament (OT) and New Testament (NT). Sources from recent literature and selected quotations from Ellen White's writings concerning these important topics are also used to develop an effective approach to fulfill the purpose of this study.

Using this information, a program to teach the members about the importance of this program was developed. A survey was taken to determine the current levels of personal Bible study and prayer among the congregation. A week of prayer and two sermons related to the themes mentioned previously were presented to the members, followed by a weekend seminar on these two topics as well. Finally, a second survey was taken to measure the members' levels of PBS and prayer in order to note any effects of the program.

\section{Overview of the Study}

This dissertation is composed of six chapters which detail the development, implementation, and results of a program to improve the church members' interest and practices in these matters. Following the introduction in chapter 1, chapter 2 examines Biblical teachings about prayer and PBS, using theological references to interpret Biblical words and verses related to the topic. This analysis provides useful information about personal spirituality. 
Chapter 3 offers an expansion to the biblical foundations of prayer and personal Bible study through an examination of the writings of Ellen White and other religious scholars. These sources provide additional valuable insight into the need for and process of developing a strategy to increase and improve these particular spiritual elements.

Chapter 4 recounts the first steps in a systematic procedure to address the prayer and PBS needs of the members. Along with a description of post-modern society, this chapter includes a step-by-step account of the meetings and sermons which were used to inform the entire congregation about the spiritual weakness in the church and to encourage them to work towards a solution.

Chapter 5 details the preparation and implementation of the week of prayer and the two weekend seminars which were designed as a result of the steps in chapter 4 .

Chapter 6 provides a summary and conclusion of the project, utilizing the results of the pre- and post-project surveys to determine the effects of this multi-step stratagem upon the congregation. This comparison is also used to detail certain recommendations for future action which would focus on ways to reach the youth and children of the church, as well as members who are currently inactive in the congregation.

A series of appendices follow the body of this dissertation, providing detailed information regarding the church membership trends, the contents of the sermons, surveys, and seminars which were presented to the members, and the numerical data resulting from the pre and post-project surveys. 
CHAPTER II

\section{BIBLICAL FOUNDATIONS}

This project requires a theological foundation for personal study and prayer in order to integrate spiritual growth with practical insights for the lives of HPHC members. The goal of this chapter is to analyze biblical teachings about prayer and PBS. Theological sources are used to interpret related biblical words and verses. The analysis provides knowledge about personal spirituality. Its results were presented to church members through a program which is detailed in chapter 3 . This chapter is divided into two major sections: the first section looks at biblical understandings of prayer, and the second section examines biblical insights on Bible study.

\section{Biblical Insights on Prayer}

A study of the word "prayer" in the Old and New Testaments is essential to elaborate a biblical strategy for this project. If there is a solid biblical foundation, it will be easier to practically develop and implement these strategies. The biblical insights on prayer will impact the personal spiritual growth of the members and motivate the brethren to an attitude of constant prayerfulness. Furthermore, the biblical models for prayer can serve as models for the members' spiritual lives. 
This section is presented in two parts. The first part analyzes some Hebrew terms for the word "prayer" and the prayer styles of OT people, while the second part examines the meaning of some Greek terms for "prayer" and the religious meaning of prayer in the NT.

\section{Prayer in the OT}

This segment analyzes the biblical Hebrew words for "prayer" and the prayer styles of the OT. A brief description of the Hebrew terms for "prayer" will enhance awareness of the spiritual messages preserved by the writers.

\section{Hebrew Words for Prayer}

There are at least twelve Hebrew terms for the noun "prayer" and the verb "to

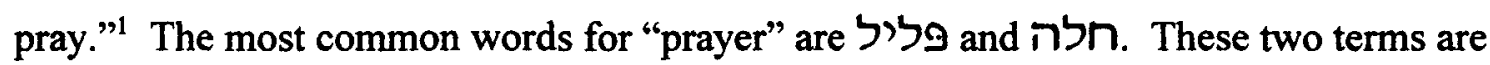
frequently used to present the prayer methods of the Jewish people. The meanings of these two words illuminate the OT use of prayer. When a true Israelite prayed, he/she did so with a deep, constant devotion to God. Prayer was at the core of the Hebrew culture. Abraham Heschel comments regarding prayer that for a Jew "to live without

'William Wilson, Wilson's Old Testament Word Studies (MacLean, CA: MacDonald Pub. Co., n.d.), 322. The twelve OT terms for "pray" and "prayer," according to Wilson, are:אנא, an interjection of entreating; חלה, to flatter, to care, to supplicate, to ask favor; תנן, to be gracious, to supplicate for pity, to entreat; לח לח, whispering, incantation, secret speech; נאנj, expressive of respectful entreaty or exhortation; ער, to meet, to entreat, to make earnest prayer which ascends like incense before God; טנע, to meet, to address with supplication, to urge; פלל, to pray; שלאל, to to ask, to give; with oneself, to complain; נפלפלה, prayer. 
prayer is to live without God." Prayer was a natural expression of the religious feelings of men and women of the biblical arena, and it occupied the central position in their lives. $^{2}$

פליל Meaning and use of

The Hebrew term פליל פל can mean intervene, interpose, and pray. ${ }^{3}$ The noun תפלה, which is derived from this verb, ${ }^{4}$ has a very rich meaning in the Hebrew Scriptures. According to Roland de Vaux, תפפלה means to pray directly to God. When a pious ancient Israelite bowed before God, he/she did it in a respectful manner. The Jews believed that God was entirely superior to them, so prayer for them took the form of "prostration, to be contrite, and assessment." The Jews knew that prayer was primarily a conversation with God which established a personal relationship with their Creator. ${ }^{7}$ Prayer was an essential part of their religion.

'Abraham J. Heschel, Moral Grandeur and Spiritual Audacity (New York: Farrar Straus Giroux, 1966), 108.

${ }^{2}$ Philip Birnbaum, $A$ Book of Jewish Concepts (New York: Hebrew Pub. Co., 1975), 654.

${ }^{3}$ Victor P. Hamilton, "פליל," Theological Wordbook of the Old Testament, ed. Laird R. Harris and Glenson L. Archer (Chicago: Moody Press, 1982), 2:725-26.

${ }^{4}$ Ibid.

${ }^{5}$ Roland de Vaux, Ancient Israel: Its Life and Institutions (Philadelphia: Westminster Press, 1975), 580.

6"Hamilton, "פלה,"2:725-26.

${ }^{7}$ De Vaux, 678. 
The Psalmist expresses the meaning of prayer explicitly: "Therefore let everyone who is godly pray to you while you may be found; surely when the mighty waters rise, they will not reach him" (Ps 32:6). The Hebrew word for "prayer" in this text is תנפלה, symbolizing direct prayer to God. ${ }^{1}$ Prayer was a tangible communication with God, not simply a matter of reciting ritual forms without meaning. ${ }^{2}$ As Kraus observes, a supplicant's prayer was his/her life and total participation, a way to express emotions spontaneously. ${ }^{3}$ The idea in this verse is to pray continually. In this aspect, prayer is more than a momentaneous act, as it is usually conceived by human beings. Prayer in this framework is an attitude of the inner soul toward God.

It seems that the Psalmist had a habit of praying all the time. He did not wait for the right time to pray or to go to the sanctuary. He learned to keep an attitude of prayer at all times. Prayer in this context is not a position of the body, a place, or audible words. Instead, prayer is an attitude of the mind. The individual who prays in such a way has reached the highest stage of prayer. He/she has delighted in the Lord's company. As Abraham Heschel pointed out, "To pray expands God's presence"4 in our

${ }^{1}$ All Scripture references are taken from the New International Version unless otherwise noted.

${ }^{2}$ Herbert Danby, ed., The Mishna (Oxford, England: Oxford University Press, 1974), 3.

${ }^{3}$ Hans J. Kraus, Theology of the Psalms (Salamanca, Spain: Ediciones Salamanca, 1979), 184-85. Kraus affirms that the people of Israel knew how to express their emotions when they prayed.

${ }^{4}$ Abraham J. Heschel, The Insecurity of Freedom (San Francisco: Harper \& Bros., 1950), 258. 
lives. Prayer for the Psalmist is an attitude. Another psalm conveys the same idea: "But I pray to you, O Lord, in the time of your favor, in your great love, $\mathrm{O}$ God, answer me with your sure salvation" (Ps 69:13). People believed that God was ready to listen to any prayer at any time and at any place.

Psalm 141:2 reads "May my prayer be set before you like incense: may the lifting up of the hands be like the evening sacrifice." Here is a clear allusion to the rites offered by the Israelite priests during the daily sacrifice. According to the book of Exodus, the Lord commanded Moses, "This is what you are to offer on the altar regularly each day: two lambs a year old. Offer one in the morning, and the other at twilight" (Exod 29:38-39). This text alludes to two events which occurred during the time of the daily sacrifice. At the time of the sacrifice, the priest burned incense before the Lord. It was known as the burnt offering and represented the merits and the intercession of Christ. ${ }^{1}$ The other allusion to this event is the grain offering by the priest. The offering was always accompanied by the burnt offering at the time of evening sacrifice. ${ }^{2}$ The time of the evening sacrifice was the $9^{\text {th }}$ hour, which was also considered the time of prayer. ${ }^{3}$

I"Psalms," SDA Bible Commentary, ed. Francis D. Nichol (Washington, DC: Review and Herald Pub. Assn., 1953-57), 3:941.

${ }^{2}$ Ibid. This idea is supported by Adam Clarke, Analytical Studies in the Book of Psalms (Grand Rapids, MI: Kregel Pub., 1979), 345.

${ }^{3}$ Ibid. Flavius Josephus, in his writings entitled Antiquities, kept the same idea that this was the time of payer. Flavius Josephus, "Antiquities," The Bible Library. [CDROM] Oklahoma City: Publisher Desk Top Data Bases. 1988. 
The one who prayed in Ps 141:2 believed that his prayer ascended before the throne of God. Prayer for him was a living experience with God at some point in the boundless universe. Here the use of תנפלה helps the reader to understand prayer as a convergent point where the transcendental, eternal, Holy God meets with the ephemeral, weak, earthly creature before the whole universe. As Abraham Heschel points out, "Genuine prayer is an event in which man surpasses himself." When people prayed, they transcended beyond. ${ }^{2}$ Although humans entered the presence of God, they recognized their littleness before the greatness of the incommensurable Eternal God. ${ }^{3}$ A prominent scholar concludes that the more the Israelites came before God, the less they spoke about self. "The 'I' is dust and ashes."' The connection with God in prayer is described as a "moment when heaven and earth kiss." Ps 25:1 says, "To you, $O$ Lord, I will lift up my soul." Prayer in the book of Psalms transports man from the island of himself to the continent of God. ${ }^{6}$

Prayer is to abandon by faith this corrupt world for a while and enjoy God's presence. As another psalm states, "You have made known to me the path of life; you

1Abraham Heschel, “On Prayer," Conservative Judaism 25, no. 1 (fall 1970): 89. ${ }^{2}$ Ibid., 83.

${ }^{3}$ Georgia Harkness, Religious Living (New York: Association Press, 1992), 48.

${ }^{4} \mathrm{Heschel}$, The Insecurity of Freedom, 256.

${ }^{5}$ The Kneeling Christian (Bacelona: Talleres Gráficos de la MCE Horeb, 1980), 62.

${ }^{6}$ Thomas H. Troeger, Rage! Reflect. Rejoice! (Philadephia: Westminster Press, 1973), 12. 
will fill me with joy in your presence, with eternal pleasure at your right hand" (Ps 16:11). Here is a clear allusion to a sweet conversation between two individuals: God and a human being. ${ }^{1}$ For the Psalmist is just an anticipation of eternity. This event moves from an impossible expectation to a realistic hope to see eternity as it is. ${ }^{2}$

The same root word mentioned in the two previous examples is also used when the book of Samuel narrates the story of Hannah while she was praying:

As she kept on praying to the Lord, Eli observed her mouth. Hannah was praying in her heart, and her lips were moving but her voice was not heard. Eli thought she was drunk and said to her, "How long will you keep on getting drunk? Get rid of your wine." "Not so," Hannah replied, "I am a woman who is deeply troubled. I have not been drinking wine or beer; I was pouring out my soul to the Lord. Do not take your servant for a wicked woman: I have been praying here out of my great anguish and grief" (1 Sam 1:12-17).

Hannah was emotionally oppressed. She was confronting problems at her home. She decided to go to the sanctuary to pour out her soul before the Lord in prayer. This prayer was an act of asking God for the deepest needs of the life and the soul. ${ }^{3}$

Definitely, Hannah was aware of her condition, and she knew what to ask of God. It has been said that as long as our prayers have a meaning to us, they will have meaning for God as well.

${ }^{1}$ Bingham Hunter, God Who Hears (Downers Grove, IL: Intervarsity Press, 1986), ${ }^{2}$ Troeger, 67.

${ }^{3}$ Bell C. Johnson, To Will God's Will (Philadelphia: Westminster Press, 1987), 51. 
For Hannah, prayer was the recognition that God occupied the center of her life. Douglas Steere describes this as "God not on the borders of life but at its center." The peculiarity of Hannah's plea was not in the words she was speaking at the sanctuary when she was rebuked by Eli. Her entreaty was to keep God at the center of her life. This could only be possible through a "frequent renewal of power through prayer." Larry Dossey, an outstanding medical doctor, has suggested, "The entire experience is prayer - not something I do or say, but something I feel."3 Evelyn Underhill offers a similar definition: "Prayer involves the whole person of intellect, of feelings, and will."" Supplication is something that erupts from the innermost part of human beings to God when they are in need. It could include words, silence, or even singing. ${ }^{5}$ For the Jews, prayer was something which came from inside and could not be expressed in audible words. $^{6}$

Hannah's petition is an example of the clamors of the inner soul, inaudible to the human ears but understandable to the Almighty God. God knows the intensity of the groans of the inner soul. He is the only one who interprets the intention of the sincere

${ }^{1}$ Douglas V. Steere, Dimensions of Prayer: Cultivating a Relationship with God (Nashville: Upper Room Books, 1967), 9.

${ }^{2}$ Harkness, 49.

${ }^{3}$ Larry Dossey, Prayer Is Good Medicine (San Francisco: Harper Collins Pub., 1996), 86.

${ }^{4}$ Evelyn Underhill, quoted in Richard Foster and James B. Smith, Devotional Classics (San Francisco: Harper Collins Pub., 1989), 113.

${ }^{5}$ Dossey, 87.

${ }^{6}$ Heschel, "On Prayer," 84. 
human spirit. God not only answered Hannah's supplication, but He also understood her difficult situation.

Unquestionably, petition to God was at the heart of the ancient Hebrew people. These examples from Psalms and Samuel give a deeper understanding of what it actually meant in its spiritual and cultural context. It was part of the cultic and secular language, as well as an integral part of the Hebrew legacy. Etan Levin, a renowned Jewish scholar, states that a Jew practiced prayer at home, at the temple, or wherever he/she was. ${ }^{1}$ A true Israelite invoked God constantly with his/her soul. ${ }^{2}$ This, whether private or collective, was considered "a personal contact between Israel and Jahweh." Prayer was an effective way to communicate with God. To a faithful Israelite, God was a personal being who could be spoken to directly without a human mediator.

Prayer also conveyed the idea of communion: "Long may he live! May gold from Sheva be given him. May people ever pray for him and bless him all day" (Ps 72:15). The Hebrew word for "prayer" in this verse is תפלה. This text pictures "a communion of the soul with God in which its [the soul's] emotions and experiences are expressed." The devoted Israelites took it so seriously that entreaty was the most

'Etan Levin, A Jew Reads the New Testament (Madrid, Spain: Ediciones Cristiandad, 1980), 233.

${ }^{2}$ Philo, De Sacrificiis, quoted in Levin, 235.

${ }^{3}$ Pious Drijves, The Psalms: Their Structure and Meaning (Montreal, Canada: Palm Pub., 1979), 16.

${ }^{4}$ Clarke, 16 . 
important matter in life for them. ${ }^{1}$ Every petition was spontaneous and came from the heart.

Meaning and use of חלה

The Hebrew term חלה primarily means "to be sick, be contrite, be empty, be weak in the knees, be covered with dust or powder, be tired, be unfit, or be praying,"2 although it can also symbolize "to be sweet, acceptable, friendly." חלה conveys the idea of "a condition, state of the body or mind." The following verses provide examples of חלה's usage.

The Psalmist wrote, "I have sought your face with all my heart; be gracious to me according to your promise" (Ps 119:58). The verb "I have sought" utilizes the Hebrew term to convey the idea of an "inward attitude." When an individual prays, he/she begs with meekness for the presence of the Lord. In this case, prayer can be an attitude in which the supplicant shows his/her state of being in the Lord's presence and seeking God's favor. ${ }^{6}$

'William Barclay, The Gospel of Matthew (Philadelphia: Westminster Press, 1977), 1:201.

${ }^{2}$ Kiel Seybold, "חלה," Theological Dictionary of the Old Testament (1990), 4:399-409.

${ }^{3}$ Wilson, 322.

${ }^{4}$ Carl P. Weber, "חלה," Theological Wordbook of the Old Testament,. ed. Laird R. Harris and Glenson L Archer (Chicago: Moody Press, 1981), 1:285-287.

${ }^{5}$ Seybold, 4:402-403.

${ }^{6}$ C.P. Weber, 1:287. 
In Zech 7:2 and 8:22, the Hebrew word חלה is used to mean "entreat."1 This usage can also symbolize a total submission to God, as in Dan 9:13. In these verses, the meaning of prayer is to implore the mercy of the Lord. This usage of cultic act, but the word חלה does not belong to the technical language of a cult.

Seybold suggests that חלה is probably everyday language used by the common people. ${ }^{2}$

The Hebrew term חלה חלה and appears in some verses such as Isa 53:10; 38:9; and $2 \mathrm{Kgs} \mathrm{8:7.} \mathrm{Specifically} \mathrm{in} \mathrm{these} \mathrm{verses,} \mathrm{חלי} \mathrm{means} \mathrm{weakness,} \mathrm{disease,}$ or someone looking sad. ${ }^{3}$ The passages mentioned above always refer to the state of the physical body or the state of the inward being. This term does not necessarily refer to a sick person; it can also indicate a faint individual who anxiously looks for help from someone.

\section{OT Prayer Styles}

Hebrew Scriptures indicate that prayer was part of the Israelites' daily life. Prayer in the ancient Israel writings, both individual and collective, was a personal relationship between God and His holy community. For the assembly of the Lord, this event connected God with His people in a familiar way. The Israelites believed that God was

\footnotetext{
'Herbert Wolf, "חלה," Theological Wordbook of the Old Testament (1981),
} 1:287. Wolf observes that when the verb חלה is used with the noun "face," this can mean "seek the favor of God." In the OT, חלה is connected with "face" thirty-six times, always in a connotation of looking for mercy because the soul is in great danger. Also in Seybold, 4:399-409.

${ }^{2}$ Seybold, 408 .

${ }^{3}$ Wolf, 1:287. 
so well-acquainted with them that their invocations were an extension of their relationship with God. It conveyed the idea of sensing God's presence. ${ }^{1}$

When an individual prayed to God in the past, he/she was aware that it did not have to be spoken out loud but could take the form of internal thoughts directed to God. ${ }^{2}$ The concept of prayer in the OT is not unilateral, but bilateral. It is a conversation with God. By dialoguing, the individual could pour out his/her heart before the throne of God. ${ }^{3} \mathrm{He} / \mathrm{she}$ spoke and listened in stillness. The concept of prayer in that time is unparalleled by any other ancient culture. In the Israelite world-view, it was direct communion with a personal God. Although the Israelites knew that God lived in heaven, when they talked, God seemed to be next to them. This concept is expressed eloquently by Solomon: "But will God really dwell on earth? The heavens, even the heavens, cannot contain you. How much less this temple I have built? Yet give attention to your servant's prayer and his plea for mercy, O Lord my God hear the cry and the prayer that your servant is praying in your presence this day" (1 Kgs 8:27-28). Although God has existed since the beginning and lives everywhere, the Jews believed that God descended to live with His people, ${ }^{4}$ always ready and willing to listen to them through prayer.

'Heschel, Moral Grandeur and Spiritual Audacity, 104.

${ }^{2}$ Walter Brueggmann, The Psalms: The Life of Faith (Minneapolis: Fortress Press, 1979), 33.

${ }^{3}$ Albert Shulman, Gateway to Judaism Encyclopedia Home Reference (New York: Thomas Yosetoff, 1971), 307-08.

4“"Psalms," SDABC, 3:965. 
The prophets and the book of Psalm introduce prayer as a spontaneous expression addressed to God. ${ }^{1}$ In the Israelite terminology, prayers emerged spontaneously from the soul. ${ }^{2}$ Sometimes individuals perceived themselves as powerless to confront their enemies, environment, and difficult living conditions. Pressure made ancient people short-sighted as they confronted seemingly meaningless situations but spontaneous prayer during times of trouble helped them to put all things in perspective. ${ }^{3}$

There were ritual prayers which priests would repeat while performing their tasks in the sanctuary or the temple, but the supplications of the common people were not necessarily tied to the ritual forms of the official cultic language. Instead, prayer as an expression of trust was appropriate at any time, in any place and circumstance of life. ${ }^{4}$ God's people were free to call upon the name of the Lord at any time and place. Basically, it was a spontaneous act rather than a repeated, meaningless form; it was an inner attitude of the individual, rather than a position of the body.

'William Dymess, Themes in the Old Testament Theology (Downers Grove, IL: Intervarsity Press, 1971), 165.

${ }^{2}$ Maximiliano García Cordero, Theology of the Bible (Madrid, Spain: Ediciones Católica S.A., 1970), 1:613.

${ }^{3}$ Christopher J. Wright, Walking in the Ways of the Lord: The Ethical Authority of the Old Testament (Downers Grove, IL: Intervarsity Press, 1995), 235. Wright believes that prayer puts people in line with the purpose of God.

${ }^{4}$ Dyrness, 166. 


\section{Prayer in the NT}

The New Testament did not develop a new conceptual background for prayer. The Early Church (EC) did not germinate a new concept of prayer different from the OT. Prayer patterns for early Christians did not clash with the models used by ancient Israelites. They only added one new element: praying in Jesus' name. This new element enhanced the dimensions of prayer and invoked Jesus' presence and power. ${ }^{1}$ To do it in the name of Jesus was also to admit his merits before the throne of God and to accept that he was their representative in heaven. ${ }^{2}$ This section analyzes some biblical Greek words for "prayer" and describes the prayer styles of the first followers of Christ.

\section{Greek Words for Prayer}

The first Christians were well acquainted with the concept of prayer in the first century. The noun "prayer" is mentioned several times in the NT; Hugo Peters suggests that various words for prayer appear more than 200 times in this portion of the

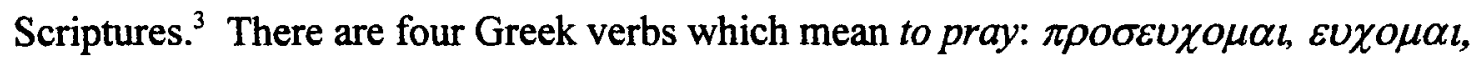
$\delta \varepsilon \sigma \mu \alpha t$, and $\pi \alpha \rho \alpha \kappa \alpha \lambda \varepsilon \omega$. Two of these, $\pi \rho \circ \sigma \varepsilon \cup \chi o \mu \alpha t$ and $\delta \varepsilon \sigma \mu \alpha l$, are particularly important for this study since they are the two most frequently mentioned verbs for "prayer" by these writers, but the following section will analyze all four Greek terms.

'Oscar Cullmann, Prayer in the New Testament (Minneapolis: Fortress Press, 1995), 99.

${ }^{2}$ Fred Fisher, Prayer in the New Testament (Philadelphia: Westminster Press, 1952), 110-111.

${ }^{3}$ Hugo M. Peters, The New Greek-Spanish New Testament Concordance (Buenos Aires, Argentina: Editorial Nuevo Mundo, 1976), 640. 


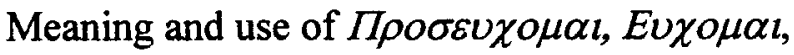
and $\Pi \rho \circ \varsigma \kappa \alpha \rho \tau \epsilon \rho \omega$

The word $\pi \rho o \sigma \varepsilon v \chi o \mu \alpha t$ is derived from two Greek words, $\pi \rho \circ \zeta$ and $\varepsilon v \chi o \mu \alpha l^{2}{ }^{2}$ $\varepsilon v \chi \circ \mu \alpha t$ is a verb meaning prayer that will be explained more fully later. The preposition $\pi \rho o \varsigma$ is a variation of $\pi \rho o \tau t$ and is probably derived from the ancient Sanskrit word prati. ${ }^{3}$ Harold Greenlee, a Greek scholar, believes that when $\pi \rho \circ \varsigma$ is attached to a verb, it forms a compound verb meaning "toward, in the direction of." This preposition has many uses: the accusative case means "toward, for the sake of, in order," the dative case represents "at, on, near," the genitive case symbolizes "for the sake of," and the infinitive case stands for "with, in company with, at, about, near." The meaning of this preposition when used before a verb is "toward, to be close to."

${ }^{1}$ A.T. Robertson and Hersey W. Davis, $A$ Short Grammar of the New Testament (Grand Rapids, MI: Baker Book House, 1989), 260.

${ }^{2}$ Barclay Newman, Jr., A Concise Greek-English Dictionary of the New Testament (London, England: United Bible Society, 1971), 76.

${ }^{3}$ Robertson and Davis, 260 . The Greek language originated from the same area as did the Sanskrit language, which would explain their similarities.

${ }^{4}$ Harold J. Greenlee, $A$ Concise Exegetical Grammar of the New Testament (Grand Rapids, MI: William B. Eerdmann's Pub. Co., 1979), 40. Sometimes the prepositions take other meanings, depending mainly on the case and the context in which they are used.

${ }^{5}$ Newman, 152. According to Newman, the different meanings which are attached to the Greek words for prayer in the NT provide a valuable insight into the influence of prepositions on verbs.

${ }^{6}$ William G. MacDonald, Greek Enchridion: A Concise Handbook of Grammar for Translation and Exegesis (Peabody, MA: Hendrickson Pub., 1995), 132. 
Two examples of $\pi \rho o \sigma \varepsilon v \chi o \mu \alpha t$ aid in understanding its meaning: Matt 6:5-16 and Acts 6:4. In chapters 5 through 7 of the book of Matthew, Jesus presented the sermon on the mount. Matt 6:5-16 is a section pertaining solely to prayer, and it contains a vital principle.

And when you pray, do not be like the hypocrites, for they love to pray standing in the synagogues and on the street comers to be seen by men. I tell you the truth, they have received their reward in full. But when you pray, go into your room, close the door and pray for your father who is unseen, then your father, who sees what is done in secret, will reward you. (Matt 6:5-6)

The principle taught in these verses is that personal prayer must be carried out in private. Entreaty was not to be displayed in public locations such as the synagogue or on the streets, as the Jews did in Jesus' time. Public prayer had its place for the early Christians, and as Hamman explains, Jesus in no way invalidated collective or public prayers. ${ }^{1}$ It should be noted that the emphasis in these verses is personal invocation. Personal prayer by the time of Jesus was losing its true sense, however not all the Jewish teachers taught their students to pray in synagogues or public streets. William Barclay believes that scarcely number of rabbis thought this way to their disciples: pray in the synagogue of your city, and if this is impossible, then pray in the field, in your house, or on your bed, or in your heart and keep silence. ${ }^{2}$

\footnotetext{
'A. Hamman, Prayer in the New Testament (Chicago: Franciscan Herald Press, 1971), 150.

${ }^{2}$ Barclay, Matthew, 1:208. The same idea is supported by John Koening, Rediscovering New Testament Prayer (San Francisco: Harper Collins Pub., 1971), 5.
} 
The efficacy of prayer does not come from us, but is derived from God. Hamman concludes, "This is why the spirit of prayer will always seek solitude." Power is action. If it does not show deeds, in reality it could be only words. Cullmann says, "Certainly prayer should also be offered in public worship, but on the other hand all prayer also requires a degree of religious awe. This should be observed both in the congregation and in the secret room in which Jesus tells the disciples to pray." The public act is just a reflection of what has happened in the secret room when the individual is in solitude with God.

An important verse that Luke wrote in relation to prayer is Acts 6:4, "And we will give our attention to prayer and the ministry of the word." The Greek word used for "attention" is $\pi \rho o \sigma \kappa \alpha \rho \tau \varepsilon \rho \varepsilon \omega .{ }^{3}$ This word means "to preserve in, to be occupied in

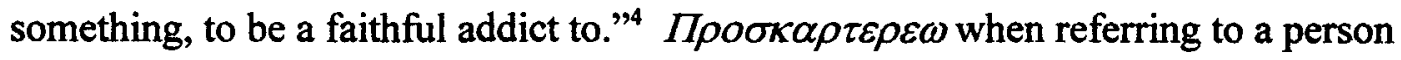
means "to be loyal to." When referring to a thing, it means "to be occupied diligently."

${ }^{1}$ Hamman, 150.

${ }^{2}$ Cullmann, 125 .

${ }^{3}$ Wesley J. Perschbacher, Refresh Your Greek: Practical Helps for Reading the New Testament (Chicago: Moody Press, 1980), 453.

${ }^{4} J o s e ́$ M. Pabón, Manual Greek- Spanish Dictionary (Barcelona, Spain: Bibliografia Departamento Editorial, 1973), 511.

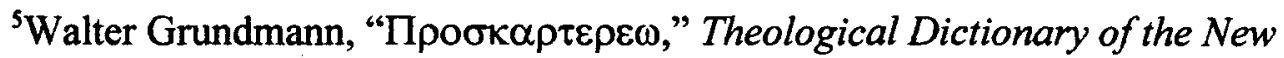
Testament, ed. Gerhard Kittel (Grand Rapids, MI: Wm B. Eerdmann's Pub. Co., 1979), 4:618. 
The Greek word $\pi \rho o \sigma \kappa \alpha \rho \tau \varepsilon \rho \varepsilon \omega$ is used ten times, and six of them appear in the context of prayer. ${ }^{1}$ The Early Christians persisted in prayer as an addiction; they could not live a single day without it. They were not fanatics, but they practiced it as way of living. Grundmann expresses this concept well: "Every great decision in the apostolic period, and in the whole life of the Early Christianity, is sustained by persistent prayer."2 The disciples transmitted an intense desire for prayer to the new converts. The primitive church spoke with God with the arduous aspiration of doing and understanding His will. Paul recommended to the Roman church, "Be joyful in hope, patient in affliction, faithful in prayer" (Rom 12:12). The church of Colossians was also admonished to "devote yourself to prayer, being watchful and thankful" (Col 4:2). To be faithful in prayer was a practice of the first Christians because in devout supplication, spiritual dryness could not last. ${ }^{3}$

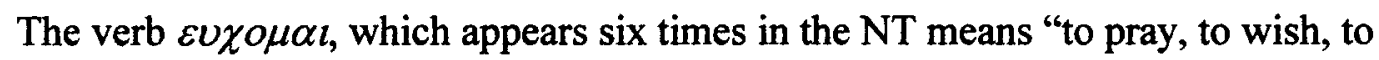
long for. " Jesús Días de León, a scholar in classical Greek, suggests that the adverb $\varepsilon v$, used for words such as $\varepsilon v \chi o \mu \alpha t$ and $\varepsilon v \alpha \gamma \varepsilon \varepsilon \lambda t o v$, conveys the idea of happiness and

'Mark 3:9; Acts 1:14, 2:42 and 46, 6:4, 8:13, and 10:7; Rom 12:12 and 13:6; Col 4:2. Peters, 495 these verses are cited.

${ }^{2}$ Grundmann, 4:618.

${ }^{3}$ William Barclay, The Letters to the Philippians, Colossians, and Thessalonians (Philadelphia: Westminster Press, 1975), 166.

${ }^{4}$ Newman, 77. 
goodness. ${ }^{1}$ Eu $\chi 0 \mu \alpha \imath$ was used in the classical times by Homer, Thusid, Pericles, and others to address any divinity. ${ }^{2}$

The verb $\pi \rho \circ \sigma \varepsilon v \chi \circ \mu \alpha t$ and the related noun $\pi \rho o \sigma \varepsilon v \chi \eta$ were used extensively in the first century. ${ }^{3}$ This verb is mentioned eighty-six times, ${ }^{4}$ and means "to pray, to ask,"5 or "asking with a fervent plea." The noun $\pi \rho \circ \sigma \varepsilon v \chi \eta$ means "prayer or place of prayer." A general overview will help to understand its use. These verses are essential to comprehend it. In Acts $16: 13,16$, the noun $\pi \rho \circ \sigma \varepsilon v \chi \eta$ is used to mean house of prayer. This word appears thirty-six times, ${ }^{8}$ but it does not always represent person in a sanctuary or in a synagogue; it can symbolize any place appointed for prayer, including a place in the open air, a house, or a temple.?

'Jesús Días de León, Course of Greek Roots (Paris, France: Librería de la V. de Ch. Bouret, 1920), 97.

${ }^{2}$ William F. Arndt and Wilbur Gingrich, A Greek English Lexicon of the New Testament and Other Early Christian Literature (Chicago: University of Chicago Press, 1957), 329.

${ }^{3}$ Peters, 93-94.

${ }^{4}$ Pabón, 510.

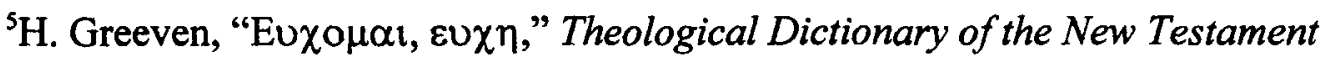
(1979), 2:775-784.

${ }^{6}$ Pabón, 270.

TNewman, 53.

${ }^{8}$ Peters, 93-94.

${ }^{9}$ Arndt and Gingrich, 720. 
Undoubtedly, the verb $\pi \rho \circ \sigma \varepsilon \cup \chi \sigma \mu \alpha t$ and the noun $\pi \rho \circ \sigma \varepsilon v \chi \eta$ are words that relate to daily Christian prayer in the perspective of the first century Christian writers. These two terms were part of their daily spiritual lives. Paul recommends that Christians must "pray continually" (1 Thess 5:17). The Greek verb used in this passage is $\pi \rho \circ \sigma \varepsilon \cup \chi \varepsilon \sigma \theta \varepsilon$, which signifies a command. ${ }^{1}$ Fred Fisher, commenting on this verse, says, "Prayer is not to be an occasional experience such as buying a new car; it is to be a constant experience such as breathing. Prayer should be persistent in the sense that it is a continuous and habitual practice of life." ${ }^{2}$ Prayer was a religious attitude rather than a position of the body, ${ }^{3}$ just as it was for the true ancient Israelites. Christianity is greatly indebted to the archaic Jewish people for its discernible concepts of prayer.

Meaning and use of $\Delta \varepsilon o \mu \alpha t$

The Greek verb $\delta \varepsilon o \mu \alpha l$, which is mentioned twenty-two times in the $\mathrm{NT},{ }^{4}$ comes from the verb $\delta \varepsilon \omega . \Delta \varepsilon \omega$ is mentioned 145 times and embraces the secular and religious domains. ${ }^{5}$ In the secular language, $\delta \varepsilon \omega$ is used in two forms: "to bind, to tie, to

'The Analytic Greek Lexicon (Grand Rapids, MI: Zondervan Pub. House, 1973),

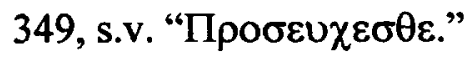

${ }^{2}$ Fisher, 124.

${ }^{3}$ Hamman, 147.

${ }^{4}$ Newman, 40.

${ }^{5}$ The Analytic Greek Lexicon, s.v. " $\Delta \varepsilon \omega . "$ 
imprison, to compel, to forbid, to prohibit" and "to lack of something, to be in need, to ask, to plead." 1 Thess $2: 9$ uses $\delta \varepsilon \omega$ to mean "hinder, bind or confine."

$\Delta \varepsilon o \mu \alpha \iota$ means "to ask, to beg intensely, to pray." This verb can also mean, "unlawful, to lack, to fall short." It can refer to a needy person or to anyone who makes a petition in a specific situation, and can also symbolize a person in the act of prayer. ${ }^{4}$ $\Delta \varepsilon o \mu \alpha t$ focuses on the need of the one who prays. For example, Jesus used $\delta \varepsilon o \mu \alpha t$ when He said, "Watch you, therefore, and pray always, that you may be accounted worthy to escape all these things that shall come to pass, and to stand before the Son of God" (Luke 21:36). $\Delta \varepsilon o \mu \alpha \imath$ in this context means "to implore, to ask something for a specific situation." Other verses which use this verb are 2 Cor 8:4, Luke 8:28, Gal $4: 12$, and 2 Cor 5:20.

Meaning and Use of $\pi \alpha \rho \alpha \kappa \alpha \lambda \varepsilon \omega$

П $\rho \alpha \kappa \alpha \lambda \varepsilon \omega$ is mentioned 106 times in the NT. It means "to beg, to urge, to encourage, to speak words of encouragement, to request, to ask, to appeal to, to console, to comfort, to cheer up, to invite, to summon." П

'Pabón, 133.

${ }^{2}$ Analytic Greek Lexicon, s.v. " $\Delta \varepsilon \omega . "$

${ }^{3}$ Arndt and Gingrich, 174.

${ }^{4}$ Greeven, “ $\Delta \varepsilon \circ \mu \alpha l, \delta \varepsilon \eta \sigma ı \varsigma, " 2: 41-42$.

${ }^{5}$ Arndt and Gingrich, 174.

${ }^{6}$ Newman, 132-133. 
where a man with leprosy begged Jesus on his knees, asking to be healed. Other examples of verses which use this word are Matt 2:18; 26:36.

\section{NT Prayer Styles}

$\Pi \rho o \sigma \varepsilon \rho \chi o \mu \alpha \iota$ and $\delta \varepsilon \sigma \mu \alpha \imath$ are two Greek words which represent prayer as allencompassing in the Christian life. These are the most common terms for referring to prayer, and they show that prayer was at the core of the daily lives of the Christians of the first century. In similar fashion to the ancient Israelites, prayer was a vital part of spiritual growth for the Christians of the first century.

Prayer as it was practiced by the disciples was not an invention of the first Christians but it had its roots in the OT. ${ }^{1}$ Joachim Jeremias asserts that "Jesus came from a people who knew how to pray."2 However, at the time of Christ's ministry, prayer among some of the Jews was in decadence. Even in the Greco-Roman world, prayers to any god were staid forms and rituals which held no personal meaning. The Greeks, who made great advances in philosophy and literature, did not contribute to mankind's knowledge and understanding of prayer. ${ }^{3}$ Regretfully, even among some Jewish leaders of the first century, prayer was in an age of deterioration. Under the influence of the Jewish religious leaders, Jewish prayers tended to be strict forms recited

${ }^{1}$ Cullmann, xiv.

${ }^{2}$ Joachim Jeremias, The Prayers of Jesus (Philadephia: Fortress Press, 1978), 66. ${ }^{3}$ Ibid. 
by memory, and not spontaneous conversations with God as they were in ancient times. ${ }^{1}$

The invocations of the Jewish leaders during the time of Christ were formal, empty, rigid forms which were repeated at specific times of day and night. ${ }^{2}$

The embryonic church broke away from the regulations and examples of the Jewish leaders regarding prayer. ${ }^{3}$ The apostles and the Christian church followed the prayer model of Christ, a pattern and style which was rooted in Hebrew Scriptures beliefs about God and communication. The old Israelite prayer motif permeated the lives of the writers of the first century church. Asking for everything in the name of Jesus is the only new element, ${ }^{4}$ although there is one other difference between the Old and New Testament prayer styles in that Christians did not link their physical position or stance with their prayers as had the Jews. Instead, the attitude of the praying person became the most important aspect of Christian prayer . As Dudley Hall explains, "In the arms of Jesus ... we [Christians] find true significance ... [as] children of God. With the attitude produced by this recognition we can live and pray."5 Hamman agrees, stating that prayer for the first Christian believers was "a religious attitude, not a position."

${ }^{1}$ Ibid., 67.

${ }^{2}$ Ibid., 79.

${ }^{3}$ Barclay, Matthew, 1:204.

${ }^{4}$ Hamman, 234.

${ }^{5}$ Dudley Hall, Incense and Thunder: Experience Intimacy and Power with God through Prayer (Sisters, OR: Multnomah Pub., 1999), 91.

${ }^{6}$ Hamman, 147. 
In John chapters 14 through 16, Christ is preparing to leave His followers and return to heaven. Four times in these three chapters, Jesus instructs His followers, "You may ask me for anything in my name, and I will do it" (see John 14:13-14; 15:7; 15:16; and 16:23). However, this instruction was not a replacement for the OT model of prayer. His instructions to ask in His name are merely an expansion of the ancient Israelites concept of prayer as communication between humans and God. Oscar Cullmann comments, "To pray in his [Christ's] name is to recognize his power, presence and intercession." Hamman supports this concept by asserting that to ask in Jesus' name is to claim His permanent presence. ${ }^{2}$ By commanding His followers to make requests in His name, Christ ensured that they would forever recall His gift to them and would rely on His grace alone for salvation. Furthermore, praying in Jesus' name would guarantee that they would not be left alone, for Christ not only promised the young church that it would receive the Holy Spirit, but He also assured it of His own continual presence.

It is important to understand that when the Early Christians prayed, they exercised faith in Christ's name. ${ }^{3}$ They manifested faith in Jesus through it and assumed the real presence of Jesus. ${ }^{4}$ Believers at that time had a passion for prayer because they were

${ }^{1}$ Cullmann, 99, 102.

${ }^{2}$ Hamman, 112.

${ }^{3}$ Donald Bloesch, The Struggle of Prayer (San Francisco: Harper Row Pub., 1980), 19.

${ }^{4}$ Fisher, 13. 
aware of the real presence of Jesus through in this event. Aware of this, Paul counseled the Thessalonians to "pray without ceasing" (1 Thess 5:17).

For the apostles, to pray in the name of Jesus meant to be familiar with His name, and to ignore His name might have hindered them from approaching God. Donald Bloesch expresses this concept well by explaining that to pray in His name is "to recognize that our prayers can not penetrate the tribunal of God unless they are presented to the Father by the Son, our Savior and Redeemer."1

\section{Biblical Insights on Personal Bible Study}

The word "study" originated from the Latin word staider, which means, "One who applied to study with or without [a] teacher."2 The first step toward understanding PBS is to examine the biblical meaning of key Hebrew and Greek synonyms for "study," since that specific word is translated in different ways its meaning should be studied carefully. This section focuses on specific OT and NT passages and phrases which refer to "study" and offers insights on how God's Word was studied in each testamental period. A few references contribute to understanding this term without using synonyms of study.

'Bloesch, 37.

${ }^{2}$ Standard Desk Dictionary (New York: Funk \& Wagnall's Pub. Co., 1974), s.v. "Study." 
Bible Study in the OT

\section{Hebrew Words for Study}

The OT writers used two words to refer to the term "study": שיח הגה It is necessary to know their meaning to understand the context in which they appeared in some books since these words were often used to allude to the investigation of the law.

\section{Meaning and Use of הגה}

The Hebrew term הגה is used both as a verb and a noun. הגה occurs twentyeight times, and ten of those occurrences are in the book of Psalms. ${ }^{2}$ This word is rendered as "meditate" in most modern translations, but the concept of "meditate" does not have the same meaning today which it did in the Israel period. For the Hebrew authors of the Bible, הגה meant "to whisper, to think, to meditate, to murmur, to speak, to reflect, to study, to recite aloud." ${ }^{\prime 3}$ An outstanding scholar in the field of spirituality believes that, for the Israelites, הגה also symbolized "ruminating."

In contrast to the Hebrew meaning for "meditation," the popular modern concept of meditation has been influenced by Eastern religious movements and the new age society to mean "an attempt to empty the mind."5 Foster elaborates that Eastern forms

${ }^{1}$ Guy B. Funderburk, "Meditation," The Zondervan Pictorial Encyclopedia of the Bible, ed. Merill Tenney (Grand Rapids, MI: Zondervan Pub. House, 1976), 4:163. 324.

2A. Negoita, "הגה," Theological Dictionary of the Old Testament (1990), 3:321-

${ }^{3}$ Ibid.

${ }^{4}$ Foster, Celebration of Discipline, 15.

${ }^{5}$ Ibid., 21. 
of meditation "stress the need to become detached from the world. There is an emphasis upon losing personhood and individuality and merging with the cosmic mind."' Modern secular meditation aims to detach and empty the soul from everything, including God. ${ }^{2}$

Although Eastern meditation has developed to completely ignore the OT concept of study and reflection, Christian meditation has continued to focus on the need for reliance and communication with God in order to know His will. Thomas Kempis compares Christian mediation with "a familiar friendship with Jesus,"3 which highlights the similarity between modern Christian meditation and the old Israelites concept of thinking, studying, ruminating, and concentrating on God.

\section{Meaning and Use of שי}

The other Hebrew term for "study" is שיח, a verb which is synonymous with שיח .הגה שיח שיח שיח can mean to "rehearse, repeat, go over a matter in one's mind." mentioned about seventeen times, including five times in Ps 119 alone. The Psalmist used this word to describe how he reflected on the Torah: "I meditate [שיח on your precepts and consider your ways" (Ps 119:15). The writers and readers showed by their usage of this word that they were very well acquainted with the concept of "study."

${ }^{1}$ Ibid.

${ }^{2}$ Donald Dorr, Integral Spirituality Resources for Community, Peace, Justice, and the Earth (New York: Orbis Book, 1990), 16-17. 106.

${ }^{3}$ Thomas Kempis, The Imitation of Christ (Garden City, NY: Image Books, 1955),

${ }^{4} \mathrm{G}$. G. Cohen, "שיח," The Theological Wordbook of the Old Testament (Chicago: Moody Press, 1980), 2:875-876. 


\section{Pertinent OT References}

The Bible is a source of hope and inspiration to Christians. ${ }^{1}$ Any individual who gets involved in personal study of the Bible will be encouraged to apply biblical truths to his human experience. ${ }^{2}$ God ordained this precept to Moses in the wilderness: "These commandments that I give you today are to be upon your hearts, impress them on your children. Talk about them when you sit at home and when you walk along the road, when you lay down and when you get up. Tie them as symbols on your hands and bind them on your foreheads. Write them on the doorframes of your houses and on your gates" (Deut 6:6-9). The personal study of the Torah was indispensable for the Israelites in the wilderness before entering the promised land. In Deut 8:3 Moses says, "He humbled you, causing you to hunger and then feeding you with manna, which neither you nor your fathers had known, to teach you that man does not live on bread alone but on every word that comes from the mouth of the Lord."

This teaches that material things are important but not essential. If people did not live according to the will of God, they would perish. The study of the word of God was most important while they wandered through the arid lands of the dry desert. As is well known, with little rain and extreme temperatures, deserts are some of the harshest places

'A.T. Hanson and R.C. Hanson, The Bible Without Illusions (Philadephia: Trinity Press International, 1989), 40.

${ }^{2}$ John Drakeford, Experience Bible Study (Nashville: Broadman Press 1974), 14. 
on earth. ${ }^{1}$ In the biblical setting, a desert can also be a waterless place, a dry area, or a waste land. ${ }^{2}$

The personal study of the Torah was important to keep them spiritually alive. The desert was not a nice place to be traveling. They needed to constantly renew their spiritual strength. There was no other spiritual source in the desert to encourage them in their pilgrimage to the Canaan land than the word of God. Ancient Israel learned on their journey to depend on the promises of God. A careful daily study of the Scriptures would endow them confidence that God would be able to fulfill what he had promised.

When Moses died in the wilderness, Joshua led the people to the promised land.

At the banks of the Jordan river, God told Joshua,

Be strong and very courageous, be careful to obey all the law my servant Moses gave you; do not turn from it to the right or to the left, that you may be successful whatever you go. Do not let this book of the law depart from your mouth; meditate on it day and night, so that you may be careful to do everything written on it. Then you will be prosperous and successful. (Josh 1:7-8)

The study was important to Joshua and the people of Israel. While they waited at the banks of the Jordan river to enter into the promised land, they exercised faith in the words of God. Through the study of the law, their spiritual life was renewed; their minds were refreshed by meditating on the Torah. ${ }^{3}$ Joshua's task to introduce the new generation to Canaan was heavy. The new cultural setting would provide him extra

${ }^{1}$ Miranda Macquitty, Desert (New York: Alfred A. Knopf, 1994), 6.

${ }^{2}$ George Giacumakis, Jr., "Desert,"The Zondervan Pictorial Encyclopedia of the Bible, ed. Merrill Tenney (Grand Rapids, MI: Zondervan Pub. House, 1976), 2:106-107.

${ }^{3}$ Funderburk, 163. 
work and a very tight schedule. No matter how busy he was, he had to meditate on the word of God. A constant study of the word of God would shape his mind with pictures of the faithful Lord. He would open icons in his mind of the powerful historical acts of God. To review the mighty works of the Omnipotent would give him assurance and encouragement to lead the people into Canaan.

In the book of Job there is a clear allusion to study the word of God. "I have not departed from the commands of his lips: I have treasured the word of his mouth more than my daily bread" (Job 23:12). According to a conservative chronology, the event of the book of Job occurred at the beginning of the second millennium before the common era. ${ }^{1}$ Job in his distress and deep grief has found comfort in the word of God. According to Job the word of God was even more important then his daily food. The importance of personal study of the scriptures was clearly seen in the days of Job.

The book of Psalms presents many references to a personal study of the Torah. "Blessed is the man who does not walk in the counsel of the wicked or stand in the way of sinners or sit in the seat of mocker. But his delight is in the law of the Lord, and in his law he meditates day and night" (Ps 1:1-2). According to Adam Clarke, the words of verse 2 are borrowed from Josh 1:8. ${ }^{2}$ The psalmist rejoiced in the Word of God just as Moses and Joshua had in ancient times. The effects of the word of God on those who faithfully read and meditated on it were displayed in everyday life. Faith, joy, and hope

${ }^{1}$ José Martínez, Job: Faith in Conflict (Madrid, Spain: Viasa I.G. Dr. Moragas y Barret, 1973), 14.

${ }^{2}$ Clarke, 31 . 
were the characteristics of those who made the Torah their meditation. "The law of the Lord is perfect, reviving the soul. The statutes of the Lord are trustworthy, making wise the simple. The precepts of the Lord are right, giving joy to the heart. The commands of the Lord are radiant, giving light to the eye" (Ps 19:7-9).

The words law, statute, precept, command, and testimony are all synonymous of the whole revelation. The psalmists were aware that only a consistent study of the Word of God could illuminate the path toward their spiritual growth. The meditation of the law constituted the backbone not only for individuals, but for the whole nation as well. The Israelites knew that to study was crucial to know the Lord. "Blessed is the man who fears the Lord, who finds great delight in his commands. His children will be mighty in the land: the generation of the upright will be blessed" (Ps 112:1-2).

The study of the revelation embraced all aspects of human life, spiritual and secular. To neglect the study of the word of God would lead men down an evil path. "I beheld the transgressors, and was grieved; because they kept not your word" (Ps 119:158). In contrast, the just guided their lives according to the word of God: "I long for my salvation, O Lord, and your law is my delight" (Ps 119:174).

True Israel focused its mind on the personal examination of the Holy Scriptures. By the time of David the words of the statutes were desirable. ${ }^{1}$ A personal study of the revelation was essential to keep the messages from God to his people fresh on their

'Dyrness, 139. 
minds. So if they studied, they would remember God's sayings. They would be present in their mind. ${ }^{1}$ The writer of Ps 119 enhances this concept beautifully:

The fear of the Lord is pure, enduring forever. The ordinance of the Lord are sure and altogether righteous. They are more precious than gold, than pure gold: they are sweeter than honey, than honey from the comb, By them is your servant warned: in keeping them there is great reward. (Ps 19:9-11)

The study of the law from early times was seen as " a supreme religious obligation." In ancient Israel it seemed that everyone was indebted to cogitate, "even the poor were obliged to set aside a period of the day to study the Torah."

During the time of Jeremiah the concept of the personal study did not vary. The idea of Job, Moses, Joshua, and David regarding the personal study of the law was kept alive through the pious people of Israel. In a time of crisis, the prophet Jeremiah exclaimed these words. "When your words came, I ate them; they were my joy and my heart's delight, for I bear your name, Oh God Almighty" (Jer 15:16). Personal study brought spiritual growth to the prophet Jeremiah, as well as a lucid perception of the will of God and a clear sense of the task with which God had entrusted him.

Jeremiah seemed to have lost his mission. Life appeared to be absurd to him. However, when he listened to God's voice through His Word, then he was able to understand everything as a whole; it fit together and made sense. The Holy Writings

${ }^{1}$ Hans R. Weber, Experiments with Bible Studies (Geneva, Switzerland: World Council of Churches, 1978), 17.

${ }^{2}$ Louis Jacobs, The Jewish Religion Companion (Oxford, England: Oxford University Press, 1995), 489, 90.

${ }^{3}$ Ibid., 49. 
provided the spiritual elements he needed to perceive the realities of the temporal and the everlasting. Without the spiritual elements, the prophet would never have come to distinguish the ephemeral from the eternal.

The OT exhibits real situations which show the importance of personal study. The study of the scriptures was essential for the spiritual growth of individuals and the nation as a whole. It would provide them with the tools to confront the harsh situations in which individuals lived. The utterance of the Lord was manifested in such times. Those who paid attention to the command to read the word daily perceived the will of God and accepted it for their lives. The scriptures present real situations which individuals of the biblical scenes went through. Discouragement, grief, guilt for sins, distrust, fear, and other circumstances did not let them focus on the Omnipotent's will. Their minds were not ready to see His hand in the events of their lives. However, when they turned to listen his message, they did it by a carefully analysis of His word. Contact with the Lord through ruminating His revelation changed the dimension in which they lived. Even the adverse environment was seen with hope and the assurance that He would bring better times. An individual reflection of the word brought them courage, faith, forgiveness, confidence, joy, and trust in the Eternal. To meditate on the everlasting's oracles brought them a sense of the presence of the Almighty in their lives and community. ${ }^{1}$

'Zwi Werbowski, The Encyclopedia of the Jewish Religion (New York: Holt Reinhart and Winston, 1996), 367. 


\section{OT Study Styles}

The book of Psalms provides many good examples of the usage of שיח הגה and These words appear more in this book than in any other OT book. Ps 1:2 relates the word הגה with the law: "But his delight is in the law of the Lord, and on his law he meditates [הגה] day and night." The Hebrew word for "law" in this Psalm is Torah;" according to this verse, a devote Israelite was one who studied (הגה) the law book every day. This interpretation of Ps $1: 2$ is supported by Josh 1:8, which advises "not let this Book of the Law depart from your mouth, meditate [הגה] on it day and night, so that you may be careful to do everything written in it." These two verses clearly indicate the emphasis Jews placed on the study of the Torah and this section of the dissertation will examine the Jewish method of studying it.

The word Torah implies more than a simple law; it can also mean direction, teaching, or doctrine. ${ }^{2}$ Hans LaRondelle asserts that this term can mean instruction or the whole revelation of God, ${ }^{3}$ and Adam Clarke agrees that this word was synonymous to the Word of God. ${ }^{4}$ For the Hebrews, this expression meant the revelation of God's will to His people, ${ }^{5}$ a clear allusion to the oracles revealed to His people.

${ }^{1}$ Robert Young, Analytical Concordance of the Bible (Peabody, MA: Hendrickson Pub., n.d.), 591.

${ }^{2}$ Ibid.

${ }^{3}$ Hans LaRondelle, Deliverance in the Psalms (Washington, DC: Review and Herald Pub. Assn., 1983), 89-90.

${ }^{4}$ Clarke, 31 .

5ohn F. Hartley, "הגה," Theological Wordbook of the Old Testament (Chicago: Moody Press, 1980), 1:403-408. 
According to most Jewish and modern conservative biblical commentators, Ps 119 is known as the Psalm of the law. ${ }^{1}$ Certain verses in Ps 119 , such as vss. 15, 24, 78, 97 , 99, and 148, describe the relation between the Torah and meditation (n'ש): "Oh how I love your law! I meditate on it all the day long" (Ps 119:97). In the Hebrew culture, to meditate (רגה) on the law could be to study, to recite, to repeat, or to reflect on God's revelation.

Why did the Israelites meditate on the law? J. F. Hartley points out that God showed His interest in all aspects of man's life through the law, giving man direction for living under His care. ${ }^{2}$ Among the ancient Hebrews, the study of the Writings was a priority in their life. Etan Levin, an outstanding scholar in Jewish studies, points out that devoted Jews were expected to be immersed in the study of God's statutes, "even in time of persecution."3

In ancient times, very few copies of the Holy Scriptures were available, so it had to be memorized. The Jews used to meditate upon, repeat, and recite God's commands when they were at home, work, or at religious festivities. The Israelites learned to perceive their environment through the prism of God's will; there was no difference between secular and religious life for them. ${ }^{4}$ As is well known, pious Israelites based

'Clarke, 295.

${ }^{2}$ Hartley, 1:403-408.

${ }^{3}$ Levin, 187.

${ }^{4}$ Gerhard Van Rad, Studies on the Old Testament (Madrid, Spain: Ediciones Sigueme, 1976), 378. 
their secular and religious experience on the deeds which the Lord had done for them through His commands, so they constantly meditated (הגה) upon His laws. ${ }^{1}$ An outstanding scholar insists that the real pious Israelite made the study of God's statutes a life's work. He/she was preoccupied with the law even as a leisure-time activity. ${ }^{2}$ Jacob Neusner explains, "By meditating on the Torah, they [the Jews] understood the realities of the world, men, and God." ${ }^{3}$ The revelation shaped Israel's community life into a vehicle of God's presence in the world. ${ }^{4}$

As a summary, study was important for Israel because it led them to a comprehensive, ethical ideal for community living. ${ }^{5}$ By studying the laws and statutes of God, the Israelites learned their responsibilities in society and understood His will. Israel was a holistic society which continually studied and examined the commandments to find the Immutable's will in religious and secular matters.

${ }^{1}$ Drijves, 38.

${ }^{2}$ Brueggmann, 190.

${ }^{3}$ Jacob Neusner, What Is Midrash? (Philadelphia: Fortress Press, 1987), 11.

${ }^{4}$ Dyrness, 135 .

${ }^{5}$ Charles H. Dodd, The Authority of the Bible (Glasgow, England: William Collins Sons \& Co., 1960), 162. 
Bible Study in the NT

\section{Greek Words for Study}

In order to understand the NT viewpoint on PBS, this section presents two Koine (vernacular) $)^{1}$ Greek synonyms for "study": $\varepsilon \rho \alpha v v \alpha \omega$ and $\alpha v \alpha \kappa \rho t v \omega$. These two words contain meanings which are vital to the purpose of this project. The methods of studying are explored through the analysis of John 5:39 and Acts 17:12, two verses which utilize $\varepsilon \rho \alpha v v \alpha \omega$ and $\alpha v \alpha \kappa \rho t v \omega$.

Meaning of $\varepsilon \rho \alpha v v \alpha \omega$

The Greek verb $\varepsilon \rho \alpha v v \alpha \omega$ is used only six times by the authors of the Holy Writings of the first century: John 5:39 and 7:52, Rom 8:57, 1 Cor 2:10, 1 Pet 1:11, and Rev 2:23. ${ }^{2}$ Originally, $\varepsilon \rho \alpha v v \alpha \omega$ was a classical academic Greek term used in the Hellenistic period, long before the time of Christ. In this classical context, the term meant "to investigate a robbery, to inquire meticulously for something, to examine a statement from the academic standpoint." ${ }^{3}$ Some first-century authors used $\varepsilon \rho \alpha v v \alpha \omega,{ }^{4}$

${ }^{1}$ Robertson and Davis, 9-10.

${ }^{2}$ Peters, 214.

${ }^{3}$ Gerhard G. Delling, "Apauvaw," Theological Dictionary of the New Testament (Grand Rapids, MI: Wm. B. Eerdmann's Pub. Co., 1979), 2:655-57.

${ }^{4}$ Arndt and Gingrich, 306. 
in the sense of "to search, to examine, to inquire, to find out," or "to track."2 Charles Dodd, a keen researcher of the Book of John, concludes that $\varepsilon \rho \alpha v v \alpha \omega$ as it is used represents a technical expression for intensive study. Dodd believes that $\varepsilon \rho \alpha v v \alpha \omega$ is the Greek language equivalent of the Hebrew term darash, which is the root of the Hebrew word Midrash, meaning "to inquire of the law." Every reference to the Greek word $\varepsilon \rho \alpha v v \alpha \omega$ conveys the idea of a careful examination or study; ${ }^{3}$ in fact, the Greek word $\alpha \rho \alpha v v \alpha \tau \varepsilon$, which means "study," is derived from $\varepsilon \rho \alpha v v \alpha \omega{ }^{4}$

\section{Meaning of $\alpha v \alpha \kappa \rho l v \omega$}

Another important Greek term for "study" is $\alpha v \alpha \kappa \rho \imath v \omega$. During the Classical Period, $\alpha v \alpha \kappa \rho \imath v \omega$ was a legal term used mainly in the courts to mean "to investigate [or] examine a process." In the post-canon Early Christian literature, $\alpha v \alpha \kappa \rho \imath v \omega$ means "a judicial hearing, to question, to examine, to discern." $A v \alpha \kappa \rho t v \omega$, which is mentioned sixteen times in the $\mathrm{NT},{ }^{7}$ is a compound word, derived from $\alpha v \alpha$ and $\kappa \rho \iota v \omega$.

${ }^{1}$ Newman, 72.

2Pabón, 253.

${ }^{3}$ Charles H. Dodd, The Interpretation of the Fourth Gospel (Cambridge, England: Cambridge University Press, 1968), 94.

${ }^{4}$ Perschbacher, 365 .

${ }^{5}$ Pabón, 41.

${ }^{6}$ Arndt and Gingrich, 56.

${ }^{7}$ Peters, 41 . Peters cites Luke 23:14; Acts 4:9; 12:19; 17:11; 24:8; 28:18; 1 Cor $2: 14-15 ; 4: 3-4 ; 9: 3 ; 10: 25-27 ; 15: 24$. 
Although the primary meaning of $\alpha v \alpha$ is "upward, on top, go over again," it is a word which can function as several different grammatical forms with various meanings. $A v \alpha$ can function as a preposition which means "this day" or "each one" in the accusative case, "on, over, on top of," or "above" in the dative case, ${ }^{3}$ or "up, upward" in the instrumental case. ${ }^{4}$ As an adverb, $\alpha v \alpha$ means "above," while, as a prefix, it can have many various meanings which require careful consideration of context. ${ }^{6}$

$K \rho l v \omega$ is a verb which primarily means "to separate, to make a distinction between, to exercise judgment upon, to estimate." This verb is used in the first-person singular of the present active indicative grammatical form. ${ }^{7}$ Pabón concludes that $\kappa \rho t v \omega$ can mean "to resolve" or "to interpret in a right way," while MacKibben affirms that $\kappa \rho \imath v \omega$ may also mean "to make a difference between ideas." 0 ther possible meanings for this expression could be "to separate, distinguish then select,

'Ibid., 18.

${ }^{2}$ Newman, 9.

${ }^{3}$ Pabón, 37.

${ }^{4}$ Robertson and Davis, 252.

5abón, 37.

${ }^{6}$ Jorge F. MacKibben, Greek-Spanish Lexicon of the New Testament (Buenos Aires, Argentina: Casa Bautista de Publicaciones, 1970), 19.

${ }^{7}$ The Analytic Greek Lexicon, 241.

${ }^{8}$ Pabón, 356.

${ }^{9}$ MacKibben, 168. 
question, examine, carefully study the scriptures, evaluate, sit in judgment, [or] call to account."

Pertinent NT references

There are many references to personal study of the Scriptures. The Jews and the Early Christians shared the ancient Writings as the word of God. Both groups intensively read the Scriptures in the first century. ${ }^{2}$ The writers of the NT alluded frequently to the OT. As an example, Ellis observes, "The writings of the apostle Paul reveal a person immersed in the content and teaching of the Psalm and prophets. ${ }^{3}$ The primitive Christians inherited it from the ancient religious Hebrew people. For a pious Israelite, the analysis of the Torah was a habit of highest importance. ${ }^{4}$ The first Christians were devoted to personal reflection on the scriptures because in them, they learned to depend totally on God.

The Gospel of Matthew draws a picture of Satan tempting Jesus in the desert. After the first temptation, Jesus replied to Satan with a quotation from the Torah: "It is written: Man does not live on bread alone, but on every word that comes from the mouth of God" (Matt 4:4). Christ knew the Scriptures because since childhood he had studied

${ }^{1}$ Arndt and Gingrich, 452.

${ }^{2}$ Early E. Ellis, Paul's Use of the Old Testament (Grand Rapids, MI: Baker Book House, 1981), 21.

${ }^{3}$ Ibid., 10.

${ }^{4}$ Werbowski, 367. 
them. He was familiar with them. ${ }^{1}$ The Lord's strength to overcome temptation consisted in His knowledge of the scriptures. He was in communion with God every day through a constant study. ${ }^{2}$

Jesus is seen in the synoptics as an individual full of the message of the prophets and Psalms. In every incident in which Jesus appears, there are allusions to the scriptures. His knowledge of the scrolls was acute because He was devoted to reading it continually. Through the study of the Torah, Christ bids his disciples to imitate His pattern of living by every word that come from The Lord's mouth. ${ }^{3}$ An outstanding scholar in the spiritual field concludes that by the studying it, "Jesus took delight in his relation with his father. He was the source of Christ's greatest joy."4

In the fourth gospel there are various passages in which Christ helped his hearers to take into consideration the study of the Holy Oracles: "You diligently study the scriptures because you think that by them you possess eternal life. These are the scriptures that testified about me" (John 5:39). The book of John shows Jesus arguing with his opponents about the true bread. Some followers "turned back and no longer followed him" (John 6:66). Jesus challenged his disciples, questioning them, “"You do not want to leave too, do you?' Simon Peter answered him, 'Lord, to whom shall we go?

1"Matthew," SDA Bible Commentary, ed. Francis D. Nichol (Washington, DC: Review and Herald Pub. Assn., 1953-57), 5:303.

${ }^{2}$ Ibid.

${ }^{3}$ Samuel K. Pipin, Receiving the Word (Berrien Springs, MI: Berean Books, 1996), 325.

${ }^{4}$ Samaan, 131. 
You have the words of eternal life (John 6:67-68). The word of Christ is equal to the word of God. Peter experienced eternal life when he listened to the Jesus' sayings. To be in contact with Jesus through His Word produces eternal life now and in the future. ${ }^{1}$ The same concept is also used in other book, "Trying to find out the time and circumstances to which the Spirit of Christ in them was pointing out when he predicted the sufferings of Christ and the glories that would follow" (1 Peter 1: 11).

Paul admonishes Timothy, "From infancy you have known the Holy Scriptures, which are able to make you wise for salvation through faith in Jesus Christ " (1 Tim 3:15). Paul speaks here in a Jewish context. The glory of the Jewish culture was to train a child from his/her earliest days in the Torah. To instruct them on the law was an obligation. ${ }^{2}$ As a son of a Jewish mother, Timothy also started his education career early. He was immersed in the OT. As a child he was instructed in the ways of the Lord through a constant study of the book. For devoted Christians of the time of Timothy knew that their spiritual growth depended on reading the writings, the law, the prophets and the saying of Jesus. The main goal of the Jews was to make their children wise through the analysis of the oracles of the Lord. ${ }^{3}$ Wisdom for them was the fear of the Lord. To the same degree that they studied the scriptures they knew God.

'Rudolf Bultmann, Theology of the New Testament (Salamanca, Spain: Ediciones Sigueme, 1978), 490.

${ }^{2}$ William Barclay, The Letters to Timothy, Titus and Philemon (Philadelphia: Westminster Press, 1975), 199.

${ }^{3}$ André Lemaire, "Education," The Anchor Bible Dictionary, ed. David Freedman (New York: Doubleday, 1992), 2:301-312. 
The study of the Scriptures was important for the Early Church. There are many passages in the NT underlying the importance of Bible study for spiritual growth. When Paul was in prison, he pleaded with Timothy, "Bring me the scrolls, especially the parchments" (2 Tim 4:13). A spiritual giant such as Paul noticed that his spiritual growth could stagnate if he stopped studying. At the end of the letter, he urged Timothy not to forget the scrolls.

The NT never contradicts the teachings of the OT. The writers were sure that the ministry of Christ and the apostles were a continuation of the plan of salvation expressed in the first testament. ${ }^{1}$ The disciples urged early Christians to study. The disciples and the first Christians knew that their spiritual growth depended on this.

\section{NT PBS Styles}

The reading of the Torah was very important for both Christians and Jews during NT times. They did not break away from the ancient Jewish patterns of studying the scriptures because the words of Christ could only be understood by perusing the prophecies concerning the Messiah. ${ }^{2}$ The young Christian church knew that the review of God's word was extremely vital to maintaining life in the spiritual realm. Christians were known in the ancient world as the people of the book. Although the ancient Roman world associated the Early Christians with Jesus Christ, some pagans believed

'F. Bruce, New Testament Development of the Old Testament Themes (Grand Rapids, MI: Wm. B. Eerdmann's Pub. Co., 1968), 21.

${ }^{2}$ Joachim Jeremias, Theology of the New Testament (Salamanca, Spain: Ediciones Sígueme, 1985), 1:240. 
that the followers of Christ were a branch of Judaism because of the Christians' diligent examination of the Torah. ${ }^{1}$

The usage of the Greek words $\varepsilon \rho \alpha v v \alpha \omega$ and $\alpha v \alpha \kappa \rho t v \omega$ in the NT clearly

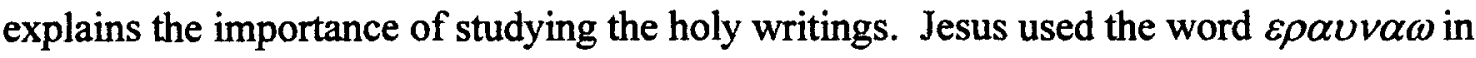
John 5:39 when He challenged "You diligently study the Scriptures because you think that by them you possess eternal life." The Jews believed that "the study of the Torah leads to life in the age to come,"2 but Jesus wished to enhance the understanding of its importance.

In John 5:39, Christ pointed out that the people of that time studied ( $\varepsilon \rho \alpha v v \alpha \omega$ ) the Torah but had refused to accept what they had learned from these studies. It contained many signs and prophecies which indicated that Jesus was the promised Messiah, the Word that became flesh (John 1:14). They needed to use their study of the statutes to prove to themselves that Jesus was the Messiah. In order to receive eternal life, it was not enough for to simply read the Torah; they needed to accept the message of Christ's coming, as expressed in the revelation, in order to accept Christ, the bearer of eternal life. ${ }^{3}$

${ }^{1}$ Williston Walker, A History of the Christian Church (New York: Charles Scribner's Sons, n.d.), 48. Charles H. Dodd supports this claim in The Bible Today (Cambridge, England: Cambridge University Press, 1968), 83.

${ }^{2}$ George Ladd, $A$ Theology of the New Testament (Grand Rapids, MI: Wm. B. Eerdmann's Pub. Co., 1974), 256.

${ }^{3}$ C. H. Dodd, The Interpretation of the Fourth Gospel, 94. 
Jesus points out that by an assiduous investigation of the Bible, the individual will know him, and will obtain eternal life. Charles Dodd proposes that eternal life is an actual experience now, but eternal life may also be for the future. ${ }^{1}$ It should be understood that the Bible does not contain life in itself. The main goal of scriptures is not to give life, but to point out Jesus the author of life. ${ }^{2}$

The gospel of John admits that when a sincere individual reads the Bible, he/she will surely find Jesus. The encounter with Jesus through the study of scriptures will make the individual able to experience eternal life in that very moment. Personal study of the scriptures provides an anticipation of eternal life in the present.

Prior to Christ's explanation in John 5:39 concerning the scriptures' true meaning, the writings were a message which the Jews restricted to geographical and cultural Jewish circles. However, after Jesus expounded its prophecies of the Messiah, the precepts became a boundless message which transcended the Jewish people and reached out to the entire world. Although Jesus was referring at that time to the Jews, He brought out an idea that can be applied to everyone. In John 5:39, Jesus established a new principle for all believers: the Torah is not an end in itself but simply a witness to the truth about Christ. ${ }^{3}$

'Ibid., 157.

${ }^{2}$ William Barclay, The Gospel of John (Philadelphia: Westminster Press, 1975), $1: 211$.

${ }^{3}$ Ladd, 266. 
Christ proved that the message of the Scriptures was a message for the entire world. The EC assumed the task of spreading this message to the world through its study and proclamation. ${ }^{1}$ For Christians, the holy book was vital in convincing other people about the importance of Christ's mission on Earth. New converts to Christianity were taught about Jesus through the OT prophecies and Christ's sayings as recorded in the Gospels. ${ }^{2}$

Because the Scriptures were now a testimony to Christ, and not a simple record of God's protection of Israel, studying the Bible became a method of examining the evidence about Jesus Christ. One powerful example of this new method of examining the Bible appears in Acts 17:11, where Luke writes about the Bereans' reaction to Paul's preaching: "Now the Bereans were of more noble character than the Thessalonians, for they received the message with great eagerness and examined the scriptures every day to see if what Paul said was true."

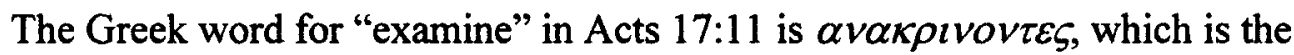
masculine first-person plural nominative participle of $\alpha v \alpha \kappa \rho t v \omega .^{3}$ Luke uses $\alpha v \alpha \kappa \rho \imath v o v \varepsilon \varsigma$ to indicate that the Bereans questioned and examined Paul's teachings about Christ. They compared scripture with scripture in order to find the truth about Christ. The Bereans did not study the Scriptures in order to discover new light or new

'Bernard Ramm, Special Revelation and the Word of God (Grand Rapids, MI: Wm. B. Eerdmann's Pub. Co., 1967), 118.

${ }^{2}$ C.H. Dodd, The Interpretation of the Fourth Gospel, 104.

${ }^{3}$ Analytic Greek Lexicon, 23. 
teachings, but to learn about a person: Jesus. The Bereans were "open minded, prepared to carefully listen and investigate,"1 and because of their diligence in study, they received a prominent place in the annals of Christian history. Through their analysis of the revelation, they "perceived the entire work of Christ in favor of the fallen human race,"2 which was the goal of all scriptural inquiry.

The examination of the Scripture has remained important to influencing and preserving the faith of Christ's believers. ${ }^{3}$ Throughout the ages after Christ's return to Heaven, Christians maintained their spirituality and belief in God by inquiring into the "inspired, trustworthy, and authoritative word of God."^ Its investigation is still important today because of the priceless message about God's love it contains. Its influence is vital for spiritual growth. The example of the first Christians is a role model for the Humboldt Park church to imitate.

\section{Summary}

The OT and NT provide powerful records of the prayer and study beliefs among the Jews and the EC. By examining the scriptures, it is apparent that this fact held a cultural and religious meaning for the Israelites and the Early Christians which was

${ }^{1}$ M. E. Blaiklock, "Berean," The Zondervan Pictorial Encyclopedia of the Bible (Grand Rapids, MI: Zondervan Pub. House, 1976), 1:524.

2“Acts," Seventh-day Adventist Bible Commentary, ed. F.D. Nichol (Boise, ID: Pacific Press Pub. Assn., 1988), 6:340.

${ }^{3}$ The two largest religious groups today that base their beliefs on part or all of the Bible are Jews and Christians. Pipin, 43-44.

${ }^{4}$ Ibid., 54. 
totally different from that of any other ancient culture. Pious people before the Messiah's time and Christian styles of praying and studying the Word offer great insights into the Hebrew and Christian beliefs about God.

Prayer in the Bible was an acknowledgment and acceptance of God's constant presence among His people. People left everything in God's hands through prayer. ${ }^{1}$ These individuals did not use long prayers to impress Him; instead, they simply prayed earnestly from their hearts. Men entreated because they knew God and because they wanted to know Him even more.

In the OT, analyzing God's word was a way to discover His will for every aspect of living. However, Jesus expanded this view of Bible study by showing its true purpose: to point to the coming Messiah. The investigation of Scripture remained important in the NT, not simply as a record of God's protection for His people, but also as a source of information regarding the ministry of Jesus Christ, the fulfillment of prophecy, and the salvation of humanity.

Prayer and Bible study still hold important roles in the spiritual development of Christians today. Supplication demonstrates a Christian's reliance and faith in God and allows God to communicate with His children. Investigation of the Scriptures reinforces and reminds us of God's wonderful plan of salvation, fulfilled through the death of His Son, Jesus Christ. By engaging in prayer and Bible study, Christians can maintain a connection with God which will help them to be effective witnesses for Him.

'Jacques Ellul, Prayer and Modern Man (New York: Seabury Press, 1970), 30. 
CHAPTER III

\section{INSIGHTS ON PRAYER AND PERSONAL BIBLE STUDY FROM ELLEN WHITE AND SOME SCHOLARS}

\section{Prayer}

The Humboldt Park congregation is part of the Seventh-day Adventist church. Generally speaking, HPHC members accept the writings of Ellen White, along with the Bible, as inspired by God. Therefore, it is essential to review what she has said regarding prayer. Selected quotes from Ellen White will benefit members and help them in their devotional lives.

It is also indispensable for the members to know that there are some scholars that do not belong to the Seventh-day Adventist church, who also support the idea that prayer is important for the development of spiritual life. These selected sources can be of help for them. Even though Ellen white may not be a scholar, some of what she says about prayer concurs with some erudite ideas.

\section{Ellen White}

Before a person is baptized as a new member, he/she studies the doctrine of spiritual gifts, and while the person studies this topic, he/she is asked whether or not he/she accepts the doctrine of spiritual gifts. 
Ellen G. White writings on prayer are very insightful. Her concepts on the topic are adopted from the Bible. She also advised church members to pray to find communion with God. In her view, invocation was the source of strength for Christians. She believed that whoever neglected prayer would soon become weary. ${ }^{1}$ On the other hand, she said that people who practice it will be refreshed by showers of divine grace. ${ }^{2}$ When Christians experience prayer their faith is envigorated. Only through earnest prayer can believers see in perspective. ${ }^{3}$

She believes that poor and illiterate church members may be unknown to the world but if they discipline themselves in prayer, their influence could be felt now and for eternity. ${ }^{4}$ In a letter sent to Elder Hull, she admonished "You have studied many works to make your discourses thorough, able, and pleasing; but you have neglected the greatest and most necessary study, the study of yourself." ${ }^{5}$ Then she proceeded to say that knowledge of self comes by meditation and prayer. ${ }^{6}$ White seems to be wellbalanced on this matter, however. She believed that prayer should not seclude one from others, rather connect them with God and with others. The Christian, like Christ, needs

${ }^{1}$ Ellen White, Testimonies for the Church (Mountain View, CA: Pacific Press Pub. Assn., 1948), 7:246.

${ }^{2}$ Ellen White, This Day With God (Mountain View, CA: Pacific Press Pub. Assn., 1970), 277.

${ }^{3}$ White, Testimonies for the Church, 7:246.

${ }^{4}$ Ellen White, Selected Messages (Mountain View, CA: Pacific Press Pub. Assn., 1958), 1:265.

${ }^{5}$ White, Testimonies for the Church, 1:433.

${ }^{6}$ Ibid. 
both the mountain and the multitude. ${ }^{1}$ If a Christian does not follow Christ's model, then his/her prayer life can become personal and selfish. ${ }^{2}$

She assures the church that the member who does not take time for prayer is prepared to make mistakes. ${ }^{3}$ Ellen White in her writings agrees with the concept of the OT and NT, "the mind should constantly be in a prayerful attitude."4 This should not be limited to specific places or positions but is rather an attitude of the being. Conviction can be obtained only through a diligent program of private personal entreaty.

White states that Christians today must exercise prayer like the disciples after the ascension of Christ. ${ }^{5}$ Personal prayer that invokes the name of Jesus is important to everyone, because it opens the heavens before us. ${ }^{6}$ She affirms that the time and the place where prayer takes place is permeated with the presence of God. ${ }^{7}$ For those who

${ }^{1}$ Ellen White, Steps to Christ (Washington, DC: Review and Herald Pub. Assn., 1977), 101.

${ }^{2}$ Ibid.

${ }^{3}$ Ellen White, "The Judgment." 33, 1879, Ellen G. White Research Center, Andrews University (EGWRC-AU), Berrien Springs, MI.

${ }^{4}$ Ellen White, "Our Need of the Holy Spirit," Advent Review and Sabbath Herald, January 3, 1907, PR 3.

${ }^{5}$ Ibid.

${ }^{6}$ Ibid.

${ }^{7}$ Ellen White, Prophets and Kings (Mountain View, CA: Pacific Press Pub. Assn., 1943), 48. 
pray in private in the inner room she says, "Holy angels stand by their side. The atmosphere that surrounds their souls is pure and holy."

In 1892 in Europe, Ellen White opened a 6:00 A.M. devotional meeting, where twenty people were attending, with a invocation expressing the idea that when one is praying, heaven seems near. ${ }^{2}$ As articulated in the OT, this is like ascending incense before the throne of God. ${ }^{3}$ It is in reality an encounter with God and with Jesus. ${ }^{4}$ Through communication with God, He develops faith in us. White said that "the prayer of faith is the key that unlocks the treasure of heaven." The individual who has the habit of prayer enters in an intimate relationship with God. She defines it as opening the heart to God as a friend. ${ }^{6}$ One can learn the will of God through prayer. Through this act individuals can perceive the still small voice of God. ${ }^{7}$ In conclusion, in

'Ellen White, Special Testimonies for Ministers and Workers, 26, Ellen G. White Research Center, Andrews University (EGWRC-AU), Berrien Springs, MI.

${ }^{2}$ Arthur White, Ellen G. White, vol. 3, The Lonely Years, 1876-1891 (Washington, DC: Review \& Herald, 1981-1986), 75-81.

${ }^{3}$ Ellen White, "Christ, the Medium of Blessings," Signs of the Times, 18 June 1896.

${ }^{4}$ White, Steps to Christ, 98.

${ }^{3}$ Ellen White, "Letter to Elder Daniels and His Fellow-Workers," Letter 49, 1903 (EGWRC-AU), Berrien Springs, MI.

${ }^{6}$ White, Steps to Christ, 92.

${ }^{7}$ Ellen White, Fundamentals of Christian Education (Mountain View, CA: Pacific Press Pub. Assn., 1923), 440. 
White's view, personal conversation with God is essential for spiritual growth because it lifts us before His presence. ${ }^{1}$

\section{Contemporary Scholars}

The HPHC members live in an age of contrast and contentions well described by Bloecsh as a place that finds "diversity versus unity, divergence versus integration, pluralism versus holism."2 In the realm of religion echoes of ecumenism are stronger than ever before. Oriental religions, once in a time of near extinction, are currently emerging stronger than ever before. Interest in the supernatural is rising, from cults to the occult. ${ }^{3}$ Even secular people nowadays are turning to spiritual movements such as the New Age. A great interest in prayer has come about as a result. Communication with the supernatural is a fad that pervades contemporary society. Even many secular M.D.'s are recommending it as a good remedy for sick people. In the introduction of his book, Dossey says, "Prayer is back. After sitting on the sidelines for most of this century, prayer is moving toward center stage in modern medicine. ${ }^{\not 4}$

In the world today, there are many movements regarding prayer. This is evident in a multicultural city like Chicago and takes myriad forms. Some people who promote

${ }^{1}$ White, Steps to Christ, 92.

${ }^{2}$ David Bosch, Transforming Mission Paradigm Shift in Theology of Mission (New York: Orbis Books, 1995), 367.

${ }^{3}$ Kent R. Hunter, Moving the Church into Action (Saint Louis, MO: Concordia Pub. House, 1989), 17.

${ }^{4}$ Dossey, 1 . 
it do not care to whom it is addressed. Many people pray because they want to feel better, or because they wish to be cured emotionally or physically. The situation among HPHC members is different: They choose to communicate with God this way because they understand Biblical principles. They have come to discern that Christian prayer is an acknowledgment of total dependence on God. ${ }^{1}$

The hardest thing for the members is to find time and a quiet place to pray in a personal way. Chicago and the suburbs, like any other contemporary metropolis, cannot escape "the tyranny of technology, the menace of mass media, and the peril of life's pressures."2 For this reason, it is imperative to help them develop a program for personal prayer. Richard Foster asserts that "prayer catapults us onto the frontiers of the spiritual life."3

This program can be adapted to the needs of the congregation. There is room for improvement in the near future. The approach of this program is simple so that the members can be motivated to implement this scheme in their personal life (see Appendix $\mathrm{F}$ for practical instructions for improving personal prayer habits). This should be a priority in life. In the book Whatever It Takes Praying, Engelkemier believes that

${ }^{1}$ Steere, 2.

${ }^{2}$ Samaan, 115.

${ }^{3}$ Foster, Celebration, 32. 
Martin Luther was right on this point: "If I should neglect prayer for a single day, I should lose a great deal of faith."1

\section{Personal Bible Study}

The Humboldt Park church accepts the Bible as a God-given source of spiritual growth whose study is important to keep each member in tune with the Almighty. Ellen White provides a valuable source of information regarding this topic. As was mentioned earlier, the members accept her directions, and they will follow her suggestion to get involved in a program of daily Bible reading. The selected quotations will help them to adapt the principles to practice.

Review of what some scholars have said about personal Bible study will be of great help to the congregation. They will notice that other Christians give great importance to the daily study of the scriptures. Emphasis on the study of the Bible within Christianity in general will motivate them for personal study.

\section{Ellen White}

HPHC members believe that in the writings of Ellen White there are practical insights regarding the importance of studying God's word. More than 3,000 quotations dealing with that topic can be found in her books. The quotations are addressed to students, individuals, ministers, institutions, church members, and to the church in general. Members of this church are convinced that these quotations are still relevant

${ }^{1}$ Joe Engelkemier, Whatever It Takes Praying: How Our Yes to What God Asks Brings His Yes to What We Ask (Fallbrook, CA: Hart Research Center, 1993), 101. 
today both individually and collectively. This section will study some quotations to help church members learn the effects of Bible study in spiritual growth.

To Ellen White, the primary goal of personal study of the Bible is steady growth. ${ }^{1}$ She suggests that church members who study the scriptures become further developed, capable of thinking more deeply, and show a greater degree of intelligence. ${ }^{2}$ Time after time, she used this phrase to encourage church members to discipline themselves to study the word of God.

The influence of Bible study on the mind is powerful. There is no other source than the Scriptures for leaving a divine impression, enlarging the mind, endowing it with new impulses and fresh vigor. ${ }^{3}$ A daily personal task such as this is essential for the spiritual growth. It will have effects not only in the spiritual realm but on the intellect as well.

The member who studies the Bible must be constant and daily personal investigation must be based on a determined discipline. Everyday contact with the holy book accelerates the concern of knowing more about the love of God. "The discipline gained by a regular study of the word of God enables him to see a freshness and beauty

\footnotetext{
'Ellen White, "Peter's Counsel to Parents." 52, (EGWRC-AU), Berrien Springs, MI.
}

${ }^{2}$ Ellen White, "The Book of Books," Advent Review and Sabbath Herald, 21 August 1888, PR 9.

${ }^{3}$ White, Fundamentals of Christian Education, 377. 
in truth that he never before discerned." An assiduous search of Scriptures will bring the reader to a deeper experience of God's love, and the member will discipline him/herself to advance to profound issues of the work of Jesus. The natural outcome will be displayed in the individual. It will give the true seeker increased mental discipline. ${ }^{2}$ Members today need to learn to be disciplined in study through a program adapted to their needs.

In today's society there are a lot of spiritual books. Bookstores are full of Christian and non-Christian manuals to show people how to grow spiritually, but none are more effective to ennoble the thoughts, feelings, and aspirations as the study of the Scriptures. ${ }^{3}$ The oldest book, the Bible, still contains the newest message. Its light shines through its sacred pages in clear, glorious beams, showing the living God to the world. $^{4}$

In Bible study, a spirit of docility and submission ${ }^{5}$ must permeate the mind of the seeker to perceive God in His magnificence. ${ }^{6}$ When someone is totally immersed in

'Ellen White, “The Importance of Bible Study," The Watchman, 12 September 1905, PR 2.

${ }^{2}$ White, "The Book of Books."

${ }^{3}$ Ellen White, "The Bible as a Text," in Testimonies for the Battle Creek Church., 8, (EGWRC-AU), Berrien Springs, MI.

${ }^{4}$ Ellen White, "Diligent and Thorough Special Education," Testimonies for Education, 218, (EGWRC-AU), Berrien Springs, MI.

${ }^{5}$ Ellen White, Testimonies on Sabbath School Work (Mountain View, CA: Pacific Press Pub. Assn., 1956), 121.

${ }^{6}$ White, Testimonies for the Church, 5:740. 
Bible issues, he/she keeps those images in the mind. Then pictures of Bible scenes are present and the individual meditates ${ }^{1}$ on them just as the ancient Hebrews and the Early Christians did.

Actually, the church is weak because a great neglect is shown in the study of the Scriptures ${ }^{2}$ in comparison with the life of Christ. Jesus studied the scrolls daily from His childhood to death. ${ }^{3}$ He manifested great scriptural knowledge in His ministry. His daily contact with the prophets and the psalms gave Him mental and spiritual power to confront the forces of evil.

If church members spend time with God through the pages of the Bible great results will be displayed in their lives. One advantage the member enjoys when studying the Book is that his/her soul is fed with the bread of life. ${ }^{4}$ The inner being is fed with the bread which descended from heaven. As a result, Christians disclose outwardly their faith, hope, and love. ${ }^{5}$ The individual who disciplines him/herself to personal daily study cannot hide the external appearance.

'Ibid.

${ }^{2}$ Ellen White, "Cease from Idolatry," Advent Review and Sabbath Herald, 2 June 1896, PR 8.

${ }^{3}$ Ellen White, Desire of Ages (Mountain View, CA: Pacific Press Pub. Assn., 1956), 50.

${ }^{4}$ Ellen White, Child Guidance (Mountain View, CA: Pacific Press Pub. Assn., 1956), 511. 192.

${ }^{5}$ Ellen White, Education (Mountain View, CA: Pacific Press Pub. Assn., 1923), 
Members must learn to study the Bible. It is not a book of odds and ends. In each part of the scriptures there is a lesson to learn. ${ }^{1}$ When individuals learn to feed themselves with the word of God, then they eat the flesh and drink the blood of Jesus. This will bring immortality to the human soul. ${ }^{2}$ Everyday contact with God through the Bible brings an anticipation of eternity. The Holy Scriptures assure Christians that eternal life is possible only through Jesus Christ.

At present, lack of daily study has produced dwarfed minds ${ }^{3}$ among members and ministers in the church. There is nothing in this world which can help the individuals to enlarge the mind, strengthen the intellect, and envigor the faculties as the study of the living oracles. ${ }^{4}$ As was previously said, the mind cannot make spiritual images if it is not fed with spiritual portraits. A disciplined individual will insert in his/her mind pictures of the biblical world, then, he/she will be capable of thinking more deeply. It will enable him/her to contemplate divine things with enriched faculties. ${ }^{5}$

White recommends to everyone that studies the Bible, to come with reverence, feeling as he/she were in the presence of God. ${ }^{6}$ If they do this, members will experience

${ }^{1}$ Ibid., 119-20.

${ }^{2}$ White, Fundamentals of Christian Education, 378.

${ }^{3}$ Ellen White, Mind, Personality, and Character (Mountain View, CA: Pacific Press Pub. Assn., 1956), 2:93.

${ }^{4}$ Ibid.

${ }^{\text {SIbid., } 1: 286 .}$

${ }^{6}$ Ellen White, Messages to Young People (Mountain View, CA: Pacific Press Pub. Assn., 1956), 261. 
His real presence when they open the Bible for pondering. They will also have more interest in spiritual things without falling into fanaticism. Instead they will become more balanced. ${ }^{1}$

In conclusion, White and the writers of the Bible agree that there cannot be spiritual growth if an individual neglects its study. The Scriptures not only expand the intellect and prepare it to contemplate eternal realities here on this planet before the consummation, but also help us live a victorious life here on earth. White concludes, "While you make the scriptures more your study, and become more familiar with them, you will be better fortified against the temptations of Satan. When inclined to speak, or act wrong, some Scriptures will come to arrest you, and turn you right."”2

\section{Contemporary Scholars}

Joseph T. Lienhard believes that biblical terms make up for part of our everyday language, but often people use these terms without realizing their origins. For example, "apple of your eye," "salt of the earth," "painted woman," and "scapegoat" are all examples of biblical phrases which are used by secular society, including Christians. ${ }^{3}$ It is important to instruct people not only to repeat these sentences, but to understand what they are saying. The main goal is to motivate them to start a meticulous program

'White, Fundamentals of Christian Education, 393.

2Ellen White, “The Weapons Against Satan's Delusions," The Signs of the Times, 18 September 1893;7.

${ }^{3}$ Joseph T. Lienhard, The Bible, the Church, and Authority (Collegeville, MN: Liturgical Press, 1995), 1. 
for searching the Scriptures with the goal of "a close communion with God in the inner chamber, faithfulness in searching His word and seeking to know His will in the scriptures."1 A daily program of personal study of the Bible will be valuable to the individual members and to the church as a whole.

A daily methodical program will shape their minds in the biblical perspective, therefore, the congregation will learn to think from a biblical standpoint. Ralph Keiper comments that to be immersed in biblical thinking is to experience its power. ${ }^{2}$ Individual members need to discipline themselves through a systematic process. Actually, many do read the Bible, but they do not have the tools to receive its full benefit. Andrew Murray observes that the secret of personal study of the Bible is to believe that God can transform human beings from sinners to saints by his grace. ${ }^{3}$

Individual daily study will empower the mind to see God as He is. There is no other way to perceive the Almighty in our lives but through dedicated study of his Holy Oracles. In another book Andrew Murray insists it is necessary to commit time each day to the study of the Bible, until you can understand the powerful relation between Jesus and his father. ${ }^{4}$ Regretfully, the entire church has not learned to create biblical portraits in their minds.

'Andrew Murray, In Search of Spiritual Excellence: Discover Power-Filled Living (Springdale, PA: Whitaker House, 1984), 75.

${ }^{2}$ Ralph L. Keiper, The Power of Biblical Thinking (Old Tappan, NJ: Fleming H. Revel Co., 1958), 153.

${ }^{3}$ Andrew Murray, The Inner Life (Springdale, PA: Whitaker House, 1984), 38-39.

${ }^{4}$ Andrew Murray, Abide in Christ (Springdale, PA: Whitaker House, 1976), 47. 
Contemporary society fills the mind with secular images. David Watson explains: "Our beliefs and behaviors are shaped by human reason and social trends." Therefore, it is necessary to instruct the members to create biblical images that come as a result of private investigation of the Book. There is a difference between the casual reading of the Bible and daily personal study focused on growth. The church must understand that determination, discipline, and the grace of God are imperative for perseverance. ${ }^{2}$

The first thing members should understand is that Bible study produces a meeting with the Savior. Samaan describes this act as "Jesus speaking to us just as He spoke to his contemporaries when He lived on earth." ${ }^{\prime 3}$ It is wonderful to read a portion of the Bible every day and reflect on it. ${ }^{4}$ The mind must be accustomed to ruminate upon the biblical scenes. If the mind is educated by a personal daily study, then the mind will take the biblical patterns, and it will be shaped according to the scriptures. Robert $M$. Mulholland comments that "Christian spiritual formation is the process of being conformed to the image of Christ."

${ }^{1}$ David Watson, Called \& Committed: World-Changing Discipleship (Wheaton, IL: Harold Shaw Pub., 1982), 102.

${ }^{2}$ R. C. Sproul, Knowing Scripture (Downers Grove, IL: Intervarsity Press, 1979), 18.

${ }^{3}$ Samaan, 143.

${ }^{4}$ Harkness, 53.

${ }^{5}$ Robert M. Mulholland, Shaped by the Word (Nashville: The Upper Room, 1985), 27. 
Devotional reading of the Bible changes the thinking patterns of the mind, and transforms them in a positive world view, of God, self, and others. ${ }^{1}$ A good way to start a program for taking advantage of the study of the Bible is to follow these practical instructions (see Appendix F for practical instructions on PBS).

In conclusion, since a PBS program had not previously been presented to the members of the HPHC, beginning one was essential. This program can be improved in the near future, if it is necessary, however at this time these methods will help when applied to the lives of HPHC members. They believe that the Holy Spirit brings conviction to the heart while they study the Bible. Members agree with Ellen White, "familiar truths will present themselves to your mind in a new aspect, texts of Scriptures will burst upon you with a new meaning as a flash of light."2

'Ibid., 33.

${ }^{2}$ Ellen White, Thoughts from the Mount of Blessings (Mountain View, CA: Pacific Press Pub. Assn., 1955), 20. 


\section{CHAPTER IV}

\section{DESIGNING A PRAYER AND PBS PROGRAM FOR THE HPHC}

Given the need for growth in spirituality, specifically in the areas of PBS and prayer identified by the survey, a program needs to be designed for the HPHC. Its purpose will be to implement the principles expressed in the previous chapter. To date, there is no record of a program designed to improve the spirituality of the members in the areas of prayer and PBS. A well-planned program can be of great help to the entire congregation. A successful program should take into consideration the society where the members live. Knowledge of the community will serve as a basis for the development of a strategy that will meet the congregation's needs.

\section{Post-Modern Society}

The American metropolis of Chicago and its surrounding suburbs is home to the members of HPHC and is also a prime example of post-modern society. According to Loytard, post-modern society is characterized by individuals who see the possibility of breaking from traditions and beginning a new way of living and thinking. ${ }^{1}$ Peter Gomez describes characteristics of the post-modern world when he says that human beings have a sense of uneasiness in their lives caused by the pursuit of material goods which

${ }^{1}$ Lyotard, 171. 
leaves them with "more toys and less satisfaction." These characteristics can be applied to some members of the HPHC.

\section{HPHC Members in Post-Modern Society}

The position of people in the post-modern community, as described by Loytard, is "like Gulliver: sometimes too big, sometimes too small, never at the right scale." Postmodernism is influenced by two dominant theories which oppose and contradict Christianity: humanistic and scientific theories. ${ }^{3}$ The members may have been greatly affected by the humanistic and scientific trends of this society. If some of the HPHC members do not receive instruction in PBS, some individuals may treat the Bible as "just another cultural artifact conditioned by its historical context and vulnerable to endless alteration of meaning through reinterpretation." ${ }^{\text {"4 }}$ In view of this, PBS among these brothers and sisters has diminished in quantity and quality. Furthermore, some members need to study prayer in a biblical perspective because today prayer seems to be "a significant individual experience."

'Peter Gomez, "Pilgrims for Spirituality," U.S. News and World Report, 23 December 1996, 80.

${ }^{2}$ Lyotard, 173.

${ }^{3}$ Brevard S. Childs, "Interpreting the Bible amid Cultural Changes," Theology Today, 45, no. 2 (July1997): 202.

${ }^{4}$ Ibid.

${ }^{5}$ Ellul, 49. 
This crisis in prayer and PBS habits is worsened by the combination of Christian faith with "purely cultural values." The Christian faith is no longer shaped by philosophy. Instead, the powerful forces of urbanization, capitalism, and technology determine how faith is measured and expressed. ${ }^{2}$ Some church members may have been absorbed by the trends of post-modernism, and as a result they lack powerful prayer and PBS habits. Unfortunately, as the false spiritual perceptions of contemporary life have continued to influence the lives of members, these perceptions have produced spiritual stagnation.

As a result of the diminished prayer and PBS, along with the cultural weakening of Christian faith, this congregation has lost its ability to minister to the surrounding community. Without communication to connect them to their Lord, members cannot hope to be prepared to spread the Good News of salvation. Many churches today are also facing this problem. John Maxwell points out, "In Acts chapter two, they [the apostles] prayed for ten days, Peter preached for ten minutes, and 3,000 were saved. Today, churches pray for ten minutes, preach ten days and three [people] get saved."

\section{Initial Steps to Address the Problem}

Prayer and study create a proper spiritual environment. Individuals who use prayer and PBS to communicate with God experience communion with Him and are prepared

'Bloesch, 11.

${ }^{2}$ David F. Wells, No Place for Truth, or Whatever Happened to Evangelical Theology? (Grand Rapids, MI: Wm. B. Eerdmann's Pub. Co., 1993), 61.

${ }^{3}$ John Maxwell, Partners in Prayer (Nashville: Thomas Nelson Pub., 1996), 10. 
to encounter the riches of God's love. Christians also have a duty to point out the realities of human society. ${ }^{1}$ In order for Christians to truly understand God's plan for humanity, they need to be in communication with God through these two spiritual channels.

The remainder of this chapter describes the process which I utilized to determine the extent of the spiritual crisis at HPHC and to present these findings to the church leaders and members. These steps were necessary in order to devise a program that included sermons, a week of prayer, and seminars.

\section{Preliminary Survey}

In order to truly understand the magnitude of the spiritual crisis facing members, a questionnaire was designed which measured the current condition of the members in areas of prayer and personal Bible study (see the questionnaire in Appendix B). The items on this survey were adapted from an unpublished survey designed by Monte Sahlin, assistant to the SDA North American Division president. ${ }^{2}$ The survey was distributed during the church service on Saturday, August 22, 1998. Ninety-eight people, which represent 80 percent of the membership, were present.

Survey results show that PBS and prayer did take place among members of the HPHC, however these practices were rather sporadic and unorganized without the discipline and consistency necessary for continued growth (see Appendix C). The

${ }^{1}$ Ibid., 39.

${ }^{2}$ Monte Sahlin, Survey (Takoma Park, MD: General Conference of Seventh-day Adventists, North American Division), provided to author in July, 1998. 
results of this preliminary survey corroborated findings from previous studies about personal spirituality, which have indicated that prayer and PBS are not practiced effectively among Christian congregations in North America. ${ }^{1}$ Joe Engelkemier cites one statistic which claims that "the average Christian in North America spends three minutes a day praying [and] an average pastor no more than seven minutes a day."2 While no ideal average is suggested by Engelkemeier, he does indicate that the time that is currently dedicated to prayer by the average Christian in North America is not sufficient.

\section{Involving the Church Elders}

In order for this project to succeed, it was necessary for the church leaders to become aware of the situation facing church members, and the preliminary survey results provided a powerful means of accomplishing this task. On Saturday, August 29, 1998, survey results were presented to the elders of the church. The elders quickly realized that the spiritual condition resembled Maxwell's description of an inactive church: "The church . . . is weak, timid, divided, and crawling instead of flying. While it has material resources to convert the world, it is restricted by its stinginess and narrowness of vision."”3

'See Appendix C for complete listing of results.

${ }^{2}$ Joe Engelkemier, 30 Days to a More Powerful Life (Nampa, ID: Pacific Press Pub. Assn., 1998), 17. The same idea is maintained by Dale Galloway, 20/20 Vision: How to Create a Successful Church with Lay Pastors and Cell Groups (Portland, OR: Scott Pub. Co., 1998), 57.

${ }^{3}$ J. Maxwell, 95. 
Following the presentation of the survey results, I engaged in two special meetings about prayer and personal Bible study with the elders. One reason for these meetings was to help them to understand that their pastor is simply a brother in Christ who struggles with the same problems as anyone else in the church. David Watson warns that every human recoils from prayer and personal Bible study; humanity's sinful nature prevents us from seeking after God in prayer. ${ }^{1}$ Rom 8:28 concurs, "We do not know what we ought to pray for, but the Spirit himself intercedes for us with groans that words can not express." The elders agreed that everyone in the church needed to learn how to pray and study God's word effectively in order to allow the Holy Spirit to transform the church into the image of Jesus and to enable the church members to touch the lives of others. ${ }^{2}$

The elders and I were convinced that a gloomy future faced the congregation if the church members continued to restrict their scope of purpose and ignore the power of prayer and PBS. Dale Galloway warns that no church can begin to accomplish God's tasks without a power center of prayer, ${ }^{3}$ and Wesley Duewel points out that there is "no easier $\sin$ than the sin of prayerlessness." "In regard to personal Bible study, Engelkemier asserts that a revival of Bible study habits in the church can change many

${ }^{1}$ Watson, 84.

${ }^{2}$ Ibid.

${ }^{3}$ Galloway, 57.

${ }^{4}$ Wesley L. Duewel, Mighty Prevailing Prayer (Grand Rapids, MI: Zondervan Pub. House, 1990), 29. 
lives and help to make the knowledge of God plain throughout the earth. ${ }^{1}$ In the light of these warnings, the elders felt that a project for increasing and improving the personal prayer and Bible study spiritual aspects of church members was necessary and would be useful to fulfill the church's God-given responsibilities.

\section{Involving the Church Board Members}

Together with the elders a plan was designed to obtain the church board members' approval of the proposed prayer and personal Bible study program. They made home visits to the church board members, during which they discussed the results of the preliminary survey. During these home visits, they also prayed with each of the board members and their families and studied Ps 1, which emphasizes the importance of reading the Bible every day. Finally, they spoke of the great spiritual revival which the church could receive if the church board would approve the proposed church-wide program of a week of prayer and seminars on prayer and PBS.

Through these home visits by the church elders, church board members realized that without proper instruction HPHC members could face the same spiritual crisis expressed by Bernard Lall that some members of Christian churches all over are becoming cold and worldly, emphasizing money-making, and pride among their members. ${ }^{2}$

${ }^{1}$ Joe Engelkemier, 30 Days to a More Powerful Life, 13.

${ }^{2}$ Bernard M. Lall, Heaven's Unlimited Power at Our Disposal (Berrien Springs, MI: Geetanjaly Pub., 1987), 73. 
Three weeks after the meeting between the church elders and myself, the board held a meeting on Saturday, September 19, 1998. One of the agenda items at this meeting was a discussion of possible strategies which could involve most or all of the church members in a program to improve their discipline in prayer and study. I was present at this meeting in my role as church pastor, and I explained to the church board that a strategy to improve personal prayer and Bible study facets of spirituality was already being implemented. I detailed the steps which had already taken place: (1) my personal experiences in prayer and personal Bible study; (2) the distribution of a spiritual survey focusing on the church members' prayer and Bible study customs; (3) the involvement of the church elders; and (4) the preparation of the church board members through home visits by the church elders.

After this explanation, the board members were assigned to small groups under the leadership of church elders. These small groups discussed the necessity, benefits, and components of a strategy for addressing prayer and personal Bible study among the whole church. Two members of the board manifested doubts about the entire project, claiming that this program would probably fail like all of the other church projects before it. Although these two dissenting members eventually agreed to assist in the strategy, they were not convinced that the program would have any success.

By the end of the meeting, the church board members agreed that this program was essential to the spiritual life of the congregation. The board members felt like Karl Barth's analysis of prayer: "For we know that our defense lies on prayer alone. We are too weak to resist the devil and his vassals. Let us hold fast to the weapons of the 
Christians: they enable us to combat the devil."1 The majority of the board members approved implementation of a program which involved:

1. Two sermons, preached on consecutive Saturday mornings, which would focus on prayer and personal study of the Bible (The church board members recommended closing each sermon with a call for members to join the project).

2. A week of prayer on spiritual growth through Bible study and prayer beginning on a Saturday morning and continuing until the following Saturday morning with meetings held every evening at 7:30 and a final meeting on Saturday morning.

3. A seminar promoting effective methods through which the whole church could learn about the importance and power of PBS and prayer (See Appendix F).

4. A follow-up survey to measure the prayer and PBS habits of the church members who participated in the previous three steps. This survey's findings would then be compared to the results of the preliminary survey, which had already been taken, in order to determine if the program caused any positive changes in the members' spiritual lives.

After approving the proposed four-step program, they committed to promoting the upcoming week of prayer and seminars among the church members through telephone calls and home visits. In order to increase the success of the project, they felt that the church members needed to be involved. The church board's active promotion of the

${ }^{1}$ Karl Barth, Prayer (Philadephia: Westminster Press, 1949), 23. He believes this was the idea of the reformers. Ibid. 
program was aimed to influence the whole church into participating and supporting the project.

\section{Involving the Entire Congregation}

On September 26, 1998, the Sabbath after this meeting, the results were presented to the entire church. The members were also informed about the proposed plan of action, which would include two sermons on October $3^{\text {rd }}$ and $10^{\text {th }}, 1998$, a week of prayer at the end of October, and a seminar on prayer and PBS in December.

I continued to meet with the elders for the following three Saturday evenings after the congregation had been informed about the project. During these meetings, the elders and I studied the Bible and prayed together. At the third Saturday evening meeting, Amparo Marcano, the leader of lay activities, joined us. Her attendance was beneficial to the progress of the program, since she is director of the missionary work of the church. Marcano's participation in the project ensured that her co-workers would provide valuable assistance in the preparation and implementation of the upcoming meetings and seminars.

There was no specific agenda for these meetings other than prayer for the church's needs and for a spiritual revival among the members. The church leaders urgently sought a renewal for the church because they knew that humans can see things from God's perspective through prayer and Bible study.' 84.

'Bob Moorehead, The Growth Factor (Joplin, MO: College Press Pub. Co., 1991), 
On the $3^{\text {rd }}$ and the $10^{\text {th }}$ of October, 1998 , I preached two sermons to the congregation. The elders and I knew that a good sermon should feed, bless, equip, and challenge the saints. ${ }^{1}$ The main goal of these sermons was to motivate the members toward prayer and PBS. Both sermons challenged the whole congregation to examine and improve their prayer and personal Bible study practices and techniques. Another goal of these sermons was to prepare the congregation for the upcoming week of prayer and seminar. (See Appendix F for a complete outline of these sermons.)

\section{Summary}

The post-modern societal atmosphere is prominent in the city of Chicago, including the area where HPHC is located. The church members have been influenced by this society, resulting in a deterioration of their spiritual lives. Previous to the initiation of the program, I distributed a survey which determined the church members' levels of interest in prayer and personal Bible study. The results of this survey were used to enlighten the church elders and board members about the spiritual dangers facing the congregation. The elders and board members approved the project. They agreed with the implementation of a four-step program to address the congregation's prayer and PBS habits, including two sermons, a week of prayer, a seminar, and a follow-up survey. The church members were informed about this program and encouraged to participate. The following chapter describes the preparation and

$$
{ }^{1} \text { Ibid., } 64 .
$$


implementation of the week of prayer, the seminar, and the follow-up survey for the congregation. 


\section{CHAPTER V}

\section{THE WEEK OF PRAYER AND THE SEMINARS}

Organization is crucial to the success of any enterprise. This project was no exception. Its planning included the assignment of responsibilities to elders and young people. The smoothness of the program depended on each individual knowing his/her duty. Everything had to be planned well in order to flow without distracting members from the message. As pastor of the church, I chose to share messages prepared especially for the occasion during both the week of prayer and the seminars.

\section{The Week of Prayer}

There were specific goals to be met, and the elders and young people were aware of these objectives. They all knew the aim of the week of prayer and seminars, knew that accomplishing it would require commitment on their part as well as the pastor's, and knew that they would need to be involved even in the details of planning.

\section{Before the Week of Prayer}

Two weeks before the week of prayer started, youth leaders worked to organize everything in respect to the week of prayer program including special music, decorations, banners, and drawings related to the week of prayer topics. Participation of elders and young people was fundamental for spiritual growth to take place during the 
week of prayer. At this point, the task of the pastor was that of a "coach" who "creates the environment."'

The greatest challenge was to increase the attendance during the week of prayer services. Prior to this week of prayer, regular attendance at weekly prayer meetings on Wednesday and Friday nights was only 10 to 15 members. The elders, church board, and young people agreed that the more an individual participates, the more he/she receives from the group. ${ }^{2}$ This participation was one goal of the week of prayer meetings. The main goal was to have a good number of members each night. If a good number of members attended these services, then many good things would happen in the church as a result. Church leaders knew that "the concern of the devil is to keep the saints from praying."

As part of the attempt to increase attendance, two young people were commissioned to make phone calls to remind the members about the week of prayer meetings. Appropriate visual material was arranged to create an appropriate environment inside the church during this week, taking into consideration that "multimedia can be used in a variety of effective ways. Beautiful images of nature, with majestic music as a background can be used to open people's eyes to God's creative

'Bill Hull, The Disciple-Making Pastor (Grand Rapids, MI: Baker Book House, 1984), 100.

${ }^{2}$ Galloway, 112.

${ }^{3}$ Engelkemier, Whatever It Takes Praying, 93. 
work." Church leaders agreed with George Hunt's statement that "we must learn to design events focusing on the people we want to reach."

The targeted audience on this special occasion was the members. Being aware that preaching is better understood in the context of worship, ${ }^{3}$ the church was decorated accordingly. Gerson Pérez, a volunteer youth pastor at the congregation, created a small prayer garden in a corner of the sanctuary for members who might want to spend time there before the service started. The idea was that the environment of the church should be meaningful, ${ }^{4}$ and should create an atmosphere of preparation for an encounter with God through songs, visual images, preaching, and prayer. The leaders of HPC agree with Hunter about how to reach members effectively during the week of prayer. Language, liturgy, and music were presented according to the audience's culture. ${ }^{5}$

Leaders believe that the same thing is happening in the HPHC as what White had described in the world--that there is confusion for lack of personal Bible study. ${ }^{6}$ The

${ }^{1}$ Lee Strobel, Inside the Mind of Unchurched Harry \& Mary (Grand Rapids, MI: Zondervan Pub. House, 1993), 183, 84.

${ }^{2}$ George Hunter, How to Reach Secular People (Nashville: Abingdon Press, 1992), 164, 65.

${ }^{3}$ Calvin Miller and Derek Morris, "A Marketplace Preaching: An Interview With Calvin Miller," Ministry 71 (November 1998): 13-14.

${ }^{4}$ Dean R. Hoge, Benton Johnson, and Donald A. Luidens, Vanishing Boundaries: The Religion of Mainline Protestant Baby Boomers (Louisville, KY: Westminister/John Knox Press, 1994), 206.

${ }^{5} \mathrm{G}$. Hunter, 66.

${ }^{6}$ Ellen White, Counsels to Parents, Teachers, and Students (Harrak, OK: Academic Enterprise, 1995), 1164. 
primary focus of this event was to motivate the church members to be involved in personal prayer and Bible study. Pastor and leaders agree that personal Bible study provides nourishment for spiritual growth. ${ }^{1}$ (For outlines of the week of prayer sermons, see Appendix D.)

Fliers were prepared for distribution during the week of prayer services to HPC members. A detailed program with the names of the participants was printed. As most participants in the program were volunteers, they were clearly instructed about the responsibilities which they would have during the meetings. ${ }^{2}$

\section{During the Week of Prayer}

The challenge during the week of prayer was to increase attendance and to prepare the church members for the upcoming seminars. Leaders realized with Stephan Grumlan that attendance was not in itself the best way to measure success. ${ }^{3}$ However, attendance in this case was an indicator of the impact of the program on the church members. The members who participated by attending this program helped us estimate how many people to expect at the seminars.

Attendance was a success if compared to the lesser attendance at night services prior to the week of prayer. The smallest attendance at the evening meetings was 43

'Pipin, 43.

${ }^{2}$ Douglas Johnson, Empowering the Volunteers (Nashville: Abingdon Press, 1991), 101.

${ }^{3}$ Stephan Grumlan, "How Do We Measure Up 'Measuring Up'?" Ministry, November 1998: 16. 
members. An average of 80 members, of approximately 130, was present each night. The pastor and leaders were aware that they needed to adjust to the culture they were trying to reach. ${ }^{1}$ On that account, the church was decorated for the occasion, ${ }^{2}$ and members were invited to come half an hour early to pray in solitude with God in a place arranged for it. Wagner observes that prayer must be practiced in the church, not in a rhetoric way but in action for growth. Growth in this case can be applied to prayer and to a personal study of the Bible. ${ }^{3}$ Special music was presented while members immersed themselves in prayer. Ann and Barry Ulanov insist that "music can offer guidance and direction to the praying person."4 Silent prayers could be a process for spiritual growth in some cases.

At the end of the first meeting the congregation was encouraged to start reading the book of Psalms. The aim was not to let them listen to personal opinions, human devices, or men's arguments, but only the voice of God through His word. ${ }^{5}$ Helping members get involved in daily personal reading would keep them from spiritual 23.

${ }^{1}$ Will MacCall, "Empty Churches or Ministry Centers," Ministry, January 1997,

${ }^{2} \mathrm{~A}$ banner was made with the title of each presentation. A prayer garden was created with artificial flowers, drawings of bushes and plants against the wall, and straw on the floor. Pictures of people praying and reading the Bible were used to decorate the inside walls of the church.

${ }^{3}$ C. Peter Wagner, Churches That Pray (Ventura, CA: Regal Books, 1993), 79-80.

${ }^{4}$ Ann Ulanov Ann and Barry Ulanov, Primary Speech: A Psychology of Prayer (Atlanta: John Knox Press, 1993), 45.

${ }^{5}$ Watson, 101. 
dryness. ${ }^{1}$ To inquire into the Bible in a deep and penetrating way will always contribute to the readers' acuteness. To choose a small portion of the Bible and observe carefully its content would enable them to become saturated with the word of God. ${ }^{2}$

At the end of the second sermon, the congregation was challenged to spend time in solitude with God through prayer. Some members live in a hostile environment. It is impossible for them to find a quiet place in the great city and suburbs for being in solitude with God. Members will know that they should spend time in solitude with God in spite of the environment. Robert Schreiter concludes: To think that Christianity will not change a situation is to rob the Christian message of its "most important part."" Praying together during the meetings is indispensable for the members. Karl Barth agrees that "if believers can pray together, they should also be able to take communion together." Besides practicing it together, another objective of the meetings was to inspire the members to experience personal communion with Jesus. Consequently, during the meetings members were encouraged to do so in solitude. The members would need to spend time alone in prayer to disclose themselves to God. There is no other time when one is so aware of him/herself as when he/she is alone in

'Steve Bakers, Good Things Come in Small Groups (Downers Grove, IL: Intervarsity Press, 1985), 80.

${ }^{2}$ Raymond Carlson, Preparing to Teach God's Word (Springfield, MO: Gospel Pub. House, 1975), 68.

${ }^{3}$ Robert Schreiter, Constructing the Local Theologies (London, England: SCM Press, 1985), 29.

${ }^{4}$ Barth, 25. 
supplication. It would afford individuals a reference frame of "who in fact we are, not who we should be, nor who we wish to be, but who we are."1

During each service, the focus was on celebrating with gladness the members' spiritual triumphs. "Celebration brings joy into life, and joy makes us strong." The same author states that every disciple should be characterized by carefree gaiety and a sense of thanksgiving. ${ }^{3}$ Every night members were encouraged to share their experiences in prayer. Members listened with joy to the testimonies of others regarding their spiritual growth through prayer.

After the Week of Prayer

At the end of the week of prayer, an increase in Bible study and prayer among members was noticeable. Due to the success of the week of prayer, leaders and members agreed to launch the next step of the project, to implement a strategy for PBS and prayer.

\section{The Seminars}

The elders and pastor believed that God meant it when He said, "if my people, who are called by name, will humble themselves and pray and seek my face and turn from their wicked ways, then will I hear from heaven and will forgive their sin and will heal their land" ( $2 \mathrm{Chr} 7: 14)$. Church leaders were sure that "reading the Bible daily

\footnotetext{
'Ulanov and Ulanov, 1.

${ }^{2}$ Foster, Celebration, 191.

${ }^{3}$ Ibid.
} 
will do awesome things to your walk with God." This Bible portion was the motto for the seminars: "All scripture is God-breathed and is useful for teaching, rebuking, correcting, and training in righteousness, so that the man of God may be thoroughly equipped for every good work" (2 Tim 3:16-17).

Flyers were designed to promote the seminars among church members (See Appendix E for flyer contents). Two six-hour weekend seminars were planned. Each seminar was to start on Friday evening from 7:00 to 9:30 and continue on Saturday from 3:00 to 6:30 p.m. The seminars were planned for the weekends of December 4-5 and 11-12. The first seminar dealt with "Implementing a Strategy for Spiritual Growth in Daily Life Through Prayer." The second seminar dealt with "Implementing a Strategy for Spiritual Growth Through Personal Daily Bible Study."

The leaders agreed on a plan for the success of the seminars. They made a commitment to make phone calls, to make home visits to the members to pray with them, and to remind them of the dates of the future seminars. Leaders' and members' participation was essential in this step of the project. At this point, they were aware that the seminars were necessary for the spiritual growth of the whole church. Members felt that the seminars' success depended on participation and attendance. They were conscious that convincing the remaining members to attend the seminars was a task for the whole church. Melvin Steinbron comments on the dangers of working alone: "Doing all my pastoring myself, trying to be a superstar, I neglected many people

'J. Maxwell, 38. 
because of time and energy limitation; I had to fail." That did not happen in this case because of careful planning and the involvement of the whole church in the project. The success of the project really must be attributed to the entire church and not only to the pastor.

The church board agreed that at the end of the seminars each participant should be provided with a certificate of attendance. This certificate would have the signature of the pastor and elders. This motivated the members to attend and participate.

A good blueprint was essential for the success of the seminar. The materials and equipment used were important in order to ensure that the targeted audience understood how to apply the presented strategies to their spiritual growth through the content of these workshops.

The church provided the appropriate equipment and material to facilitate a good atmosphere for learning the seminar's contents. This included two boards: one magnetic board used with neon black lights to highlight phrases with main ideas and a white board to write on. An overhead projector was used to show transparencies with pictures related to these topics. A slide projector was used to show scenes depicting the Bible portions chosen for this occasion.

A handout was distributed to members at the beginning and end of each seminar. The handouts passed out at the beginning were an outline of the lecture (see Appendix $\mathrm{G}$ for translations of these handouts). The handouts at the end added to the lectures'

'Melvin J. Stenbron, Can a Pastor Do It Alone? (Ventura, CA: Regal Books, 1987), 22. 
main ideas. Giving an outline at the beginning helped members to focus throughout the seminar. The handouts shared at the end helped them to retain the main ideas for future personal review. A sheet of paper was distributed at the end of each seminar, where members signed a covenant to study the Bible and pray for their spiritual growth (see Appendix $G$ for translations of the handouts used).

The methodology followed to teach members included lectures and short periods of time for group discussion. Members were divided into groups of eight. The leaders were elders and Sabbath school teachers who guided the groups and moderated discussion time. At each meeting, there were three occasions for group discussion: one at the beginning, one at the middle, and one right before the end. Group discussion is a great asset in any class. ${ }^{1}$ It has been proven that participating in small groups helps to enhance learning and retention. ${ }^{2}$ Group discussion provides adults with the opportunity to learn new abilities and improve old abilities. ${ }^{3}$

During the group discussion, every group member shared the approach he/she used to study the Bible and pray. In the middle of each seminar, they discussed the following topic: What is the best time of day for personal Bible study and prayer? Phillip Samaan recommends that Bible study take place early in the morning. He says

'Elizabeth Cohen, Teaching College (New York: Columbia University College Press, n.d.), 4.

${ }^{2} \mathrm{Jim}$ Cummings, Empowering Minority Students (Sacramento: California Assn. for Bilingual Education, 1989), 76.

${ }^{3}$ Dorothy Russell, "An Analysis Development Theory and Invitational Education," in Advance Invitation Thinking, ed. John Novak (San Francisco: Caddo Gap Press, 1992), 160. 
that is the best way to begin a day-energized by spiritual food. However, if it is impossible given the circumstances around us, then it can be done at noon, in the evening, or even at night. The idea is to meet God for spiritual nourishment. ${ }^{1}$ Many members of the HPHC leave for work before sunrise and get back after dark at night, so the recommendation for them is to spend time with the Lord at any time of the day when they consistently can. The objective of this question was to show them that there is no mandatory specific time of the day for prayer and PBS. The conclusion of this question among the participants was that there is not one specific time. Each member selected the best time of day and place to achieve the maximum spiritual growth.

Paper and pencil were provided to members to write down the facts they considered important. Pedagogic methods such as summary, repetition, and writing main phrases on a magnetic board with black lights were utilized. Banners were put up in the church to visually reinforce the main ideas of the instructions.

The combined approach of discourses plus audiovisuals created an environment for learning. Lectures, the magnetic board with black lights, slides, and transparencies made an impact on members' minds. It has been proven that speeches plus audiovisuals plus practice make teaching most efficient and lasting. The equipment and the materials bought by the church will be used for other future events.

The survey presented at the end of the seminar indicated that there cannot be a revival and spiritual growth in each individual if there is a lack of prayer and personal Bible study. The survey given at the end of the seminar indicated attendees perceived 
the urgency of implementing a daily program for their spiritual growth. Members and leaders alike were aware of this effort. The results of the post-project questionnaires, which are discussed in chapter 6 , also revealed an increase in personal study of the Bible and prayer (see Appendix C for survey results). 


\section{CHAPTER VI}

\section{EVALUATION, CONCLUSION, AND RECOMMENDATIONS}

This chapter evaluates the implementation of prayer and personal Bible study in the HPHC. The evaluation is based on the week of prayer, the seminars, and their results. This chapter also provides a brief summary of the project and recommendations for future studies regarding personal study of the Bible and prayer.

\section{Evaluation}

The goal of the project was to encourage spiritual growth among participating church members. For obvious reasons, measuring spiritual growth objectively would be almost impossible. The results of spiritual growth in the members' lives, on the other hand, often become a measurable indicator when change occurs. Several factors are taken into consideration in the analysis of this project. Spiritual growth becomes evident through increase in attendance, tithing, and outreach activity. Outcomes are further gauged by members' own self-analysis on the issues of prayer and PBS. Survey questions included measures for both attitudes and activities. These provided a meaningful although limited view of members' experience and perceptions. To promote honesty, the instrument was administered in a non-threatening way through an anonymous survey administered both before and after the project. 
One objective for this project was to reach 100 percent of the $1998 \mathrm{HPHC}$ membership, which equaled 134 people. However, only 59 to 77 percent of the total membership (79 to 104 people) were present during the week of prayer. Several things may have impeded attendance of the rest of the members. Some members live in the suburbs up to an hour away from the church. In the evenings, during the time when the meetings were held, traffic in highways is too heavy to allow easy and quick driving into Chicago. ${ }^{1}$ Other members had to work in the evenings. Finally, certain church members attend only the sermon on Saturday morning and have always demonstrated little interest in other church programs.

The members who did attend the week of prayer showed up very consistently, except for Tuesday, when the attendance was down to a mere 43 people ( 32 percent of the total membership). No additional reason for the low attendance on this one day was found. At the end of the week of prayer, approximately 35 members joined the group of elders to pray and study the Bible on Saturday afternoon. Undoubtedly, the week of prayer helped to prepare the members for the seminars. The members who attended were motivated by the messages and impact of the week of prayer. The average attendance during this week was 80 members per night, which represents 59 percent of total membership.

'Cornelio Molina, interview by author, 3 October 1998. 
Survey Administration

As described in chapter 4, a two-part survey was administered to all the church members during church services on Saturday, August 22, 1998. This survey was used to assess the pre-project conditions, attitudes, and needs of the HPHC membership in the areas of personal prayer and Bible study; 104 members (76\%) completed and returned this preliminary survey (see Appendix C).

The week of prayer, which was held from October 31 through November 7, 1998, was followed by a weekend seminar on prayer. The effects of this seminar, which took place on December 4 and 5,1998, were measured by the administration of a post-project prayer survey which was given at the conclusion of the seminar. This post-seminar survey was completed and returned by 82 people (61\%). On the following weekend (December 11 and 12, 1998), a seminar on personal Bible study was held, followed by administration of a post-project PBS survey. A total of 79 seminar attendees completed and returned this survey (see Appendix C). Although response numbers are slightly lower for both post-project surveys, all respondents in the follow-up surveys also participated in the pre-project survey. For this reason some comparisons can be made with a fair amount of accuracy.

The week of prayer and the seminars brought about wonderful effects in the spiritual lives of the HPHC members. Changes encompassing both attitudes and actions in the participants who took part in the study are reflected in table 1. 


\section{TABLE 1}

\section{SURVEY RESULTS}

\begin{tabular}{|c|c|c|c|c|c|c|}
\hline & Prayer Questions \& Responses & $\begin{array}{l}\text { Pre- } \\
\text { Survey }\end{array}$ & $\begin{array}{l}\text { Post- } \\
\text { Survey }\end{array}$ & PBS Questions \& Responses & $\begin{array}{l}\text { Pre- } \\
\text { Survey }\end{array}$ & $\begin{array}{l}\text { Post- } \\
\text { Survey }\end{array}$ \\
\hline \multirow[t]{6}{*}{1.} & Do you feel the need to pray? & $\%$ & $\%$ & $\begin{array}{l}\text { How often do you feel the need to study the Bible } \\
\text { for spiritual growth? }\end{array}$ & $\%$ & $\%$ \\
\hline & Never & 3.8 & 0 & Never & 9.6 & 0 \\
\hline & Sometimes & 46.3 & 15.2 & Sometimes & 50 & 14.6 \\
\hline & Only in church & 6.7 & 0 & Only in church & 7.7 & 2.4 \\
\hline & At meals & 14.4 & 1.3 & When there are problems & 13.5 & 6.2 \\
\hline & Frequently & 28.8 & 83.5 & Frequently & 19.2 & 76.8 \\
\hline \multirow[t]{5}{*}{2.} & \multicolumn{3}{|l|}{ How important is prayer in your life? } & \multicolumn{3}{|l|}{ How important is personal study of the Bible for you? } \\
\hline & Not important & 0 & 0 & Not important & 0.9 & 0 \\
\hline & I don't know & 7.7 & 1.3 & I don't know & 2.9 & 0 \\
\hline & Sometimes it is important & 24 & 3.8 & Sometimes it is important & 44.2 & 13.4 \\
\hline & Very important & 68.3 & 94.9 & Extremely important & 52 & 86.6 \\
\hline \multirow[t]{6}{*}{3.} & \multicolumn{3}{|l|}{ How many times do you pray every day? } & \multicolumn{3}{|c|}{$\begin{array}{l}\text { How much effect does personal Bible study have on your spiritual } \\
\text { growth? }\end{array}$} \\
\hline & I don't pray & 0.9 & 0 & No effect & 0.9 & 1.2 \\
\hline & I don't know & 16.4 & 2.5 & I don't know & 6.7 & 2.4 \\
\hline & 1 time & 27.9 & 15.2 & Some & 21.2 & 4.9 \\
\hline & Mealtimes \& before going to bed & 28.8 & 6.3 & It has a big effect & 71.2 & 91.5 \\
\hline & Frequently $/ 5-10$ times or more & 62.2 & 76 & & & \\
\hline \multirow[t]{7}{*}{4.} & \multicolumn{3}{|c|}{$\begin{array}{l}\text { Do you believe that prayer is important for your spiritual } \\
\text { growth? }\end{array}$} & \multicolumn{3}{|l|}{ How many times per week do you read your Bible? } \\
\hline & I don't believe so & 0 & 0 & I don't read it & 9.8 & 3.7 \\
\hline & I don't know & 12.5 & 2.5 & Only in church & 24 & 8.5 \\
\hline & Sometimes & 14.4 & 2.5 & 2 times & 28.8 & 9.8 \\
\hline & \multirow[t]{3}{*}{ Extremely important } & 73.1 & 95 & 3 times & 11.5 & 15.8 \\
\hline & & & & 5 times & 14.4 & 25.6 \\
\hline & & & & More than 5 times & 11.5 & 36.6 \\
\hline 5. & \multicolumn{3}{|c|}{$\begin{array}{l}\text { Do you believe that a seminar on praying more effectively is } \\
\text { necessary/was helpful? }\end{array}$} & \multicolumn{3}{|c|}{$\begin{array}{l}\text { Do you believe that a seminar on personal Bible study is necessary/was } \\
\text { helpful? }\end{array}$} \\
\hline & I don't believe so/Did not help & 1 & 2.5 & 1 don't believe so/It did not help me & 0 & 1.2 \\
\hline & I'm not sure & 14.4 & 2.5 & I'm not sure & 17.3 & 6.1 \\
\hline & Extremely importan $V Y$ es, it helped & 84.6 & 95 & Extremely important/Yes, it helped me & 82.7 & 92.7 \\
\hline
\end{tabular}


Of participants who said they felt the need to pray "never," "sometimes," "only in church" or "at meals" before the project, 54.7 percent said they felt the need to pray "frequently" after the project, bringing the total in this category up from 19.2 percent to 83.5 percent. Participants also indicated that prayer was more important to them and their spiritual growth (see questions 2 and 4 ) and they prayed more frequently (see question 3). While 84.6 percent thought a seminar on effective prayer was necessary, even more $(95 \%)$ were sure it had helped them improve their program of personal prayer.

After the project, over half (57.6\%) indicated that they felt an increased need to study the Bible for spiritual growth, about a third (34.6\%) said the Bible was more important to them, and 91.5 percent thought PBS had a significant effect on their spiritual growth (see questions 1,2, and 3). Of the participants, 40.6 percent responded that they read the Bible more frequently than before (compare responses in Table 1), and 92.7 indicated that the seminar had helped them to improve their study of the Bible.

Although the validity of these responses is largely dependent on respondents' honesty and frequency, these survey results can be used as a general indication that some positive change occurred as a direct result of the project.

\section{Church Member Observation}

Many tangible results of increased spirituality have become evident in the church since the conclusion of the project. As a result of the week of prayer, in the months following its completion, 12 new members have joined the church, 7 by baptism and 5 by profession of faith. Church members have been more involved in sharing the Good 
News with unchurched people. A group of young people have organized themselves to help the pastor give Bible studies to unbelievers. This has never happened before in the history of the church.

At the beginning of November 1998, church members felt that it was time to plant a new church. A group of ten members moved to a nearby suburb, and they have established a new company of believers. This new group, which is growing rapidly, meets each Saturday morning with the help of other members. The new company now has more than 60 members and 15 visitors who attend regularly but are not baptized yet. Given the growth in membership and tithes, this new group is an organized church with its own pastor.

The former members who moved to plant the new congregation have already been replaced by visitors who will soon become new members. Many guests are present each Saturday, so that the church is always full. In July 1999, members transferred to other churches in the division, and more than 25 members have been dropped from the church books as "missing." In spite of this loss, the church experienced an increase in tithes and offerings over the past three months. ${ }^{1}$

After the week of prayer and the seminars, attendance at regular Wednesday and Friday night church services has also increased. Attending members have benefitted from the blessings they received during the seminars and the week of prayer.

Furthermore, members now participate more in all church programs. Elders and the

${ }^{1}$ According to records of the Treasury Report of the Illinois Conference of Seventh-day Adventists, November 1998. 
director of lay activities are promoting prayer and home visits, encouraging members to keep on studying the Bible. As a result of the work of the young people a new baptismal class has originated. Regarding prayer, Tom Elliff comments that "God has given us prayer, not primarily as a method for getting things or changing circumstances, but as a means of cooperating with him."1 The members are beginning to understand what John Maxwell wrote in his book Partners in Prayer: "Prayer without action is presumption."2 A revival cannot begin in a church if there is not prayer and personal Bible study among its members. $^{3}$

\section{Conclusion}

At the beginning, this project was intended as a strategy for HPHC members to grow spiritually through PBS and prayer. The plan consisted of preparing an appropriate church atmosphere with an attractive decor and warm interpersonal relationships before the week of prayer and conducting a seminar on PBS and personal prayer. One goal of this project was to get as many members as possible involved. Another goal was to evaluate the effects of the week of prayer and the seminars. The project's outcomes were measured through questionnaires given to church members before and after its implementation and through observation of changes in attendance at regular services. Member involvement in different church activities was also monitored and evaluated. Based on the benefits experienced by the congregation, the strategy was successful.

'Tom Elliff, A Passion for Prayer (Wheaton, IL: Crossway Books, 1998), 15.

${ }^{2} \mathrm{~J}$. Maxwell, 23.

${ }^{3}$ Engelkeimer, 30 Days, 96-97. 
The review of OT, NT, and Ellen White references to personal Bible study and prayer opened to the members a new dimension for perceiving spiritual growth in its real scope. The practical suggestions made about personal study of the Bible and prayer also gave the members useful means by which to start daily personal spiritual programs (see Appendix F). Before the project, some members read the Bible and prayed, but they did not follow any systematic program. At the present time, these suggestions are practiced by the majority of the members.

As the pastor of the congregation and the author of this project, I was personally enriched and enlightened, not only by researching this topic and planning the strategy for the members, but also by putting the principles of this project into practice in my own spiritual life. The theories and suggestions of this study were gradually incorporated into my own life throughout the course of the investigation. In summation, I was immersed in this project not only during the investigation process, but also in the time of the implementation, in the same manner as any other member of HPHC because it was a spiritual necessity of PBS and prayer for the members, liders and pastor as well.

Maxwell supports this idea that can be applied in this case, a pastor is not a spiritual giant, but simply a brother in Christ.'

'J. Maxwell, 11. 


\section{Recommendations}

For future research, it would be good to do a project of personal Bible study and prayer specifically for teens and young people. There are members within this age group in this church. In this project, the week of prayer and the seminars were directed towards the congregation as a whole. The strategy was for the members in general and did not consider any specific age group. An approach designed specifically for young people which deals with their daily concerns would most likely reach more of the youth in a meaningful way. Perhaps this would have an even more profound impact on the young people and their participation in church activities.

A future project including strategies to incorporate inactive members would be extremely valuable. This project's main focus was on encouraging growth in active members, however an effort specifically targeted for inactive and semi-active members could also significantly affect both these members and the church overall. Semi-active members would be defined as those who attend only Sabbath morning services or are marginally involved in the church. Inactive members would mean those who do not attend on a regular basis and/or are not consistent in tithing.

This project did not consider how many seminars and weeks of prayer during the year would be necessary for continued growth in the areas of prayer and PBS. It would be very insightful to administer the post-project surveys on prayer and personal Bible study once more in order to ascertain the continued effects of the project. A readministration of the survey could point out potential long-term outcomes of the project; this information would be useful for any future spiritual projects in HPHC. This project 
only opened the door for future research in the field of spirituality; and the beneficial results of this project should definitely encourage the church to continue striving for spiritual growth and improvement. 


\section{APPENDIX A}

\section{HPHC MEMBERSHIP DATA, 1982-1998}

\begin{tabular}{|c|c|c|c|c||c||c|c|c|c||c||c|}
\hline Year & Members & Baptisms & $\begin{array}{c}\text { Profession } \\
\text { of Faith }\end{array}$ & $\begin{array}{c}\text { Transfers } \\
\text { In }\end{array}$ & $\begin{array}{c}\text { Total } \\
\text { In }\end{array}$ & Death & Apostasy & $\begin{array}{c}\text { Transfers } \\
\text { Out }\end{array}$ & Lost & $\begin{array}{c}\text { Total } \\
\text { Out }\end{array}$ & Members \\
\hline \hline 1982 & 0 & 37 & 2 & 85 & 124 & 0 & 2 & 7 & 0 & 9 & 115 \\
\hline 1983 & 115 & 17 & 0 & 3 & 20 & 0 & 12 & 6 & 0 & 18 & 117 \\
\hline 1984 & 117 & 52 & 0 & 7 & 59 & 0 & 13 & 0 & 0 & 13 & 163 \\
\hline 1985 & 163 & 50 & 0 & 15 & 65 & 1 & 19 & 7 & 6 & 33 & 195 \\
\hline 1986 & 195 & 32 & 1 & 4 & 37 & 0 & 15 & 27 & 5 & 47 & 185 \\
\hline 1987 & 185 & 19 & 2 & 1 & 22 & 0 & 0 & 7 & 0 & 7 & 200 \\
\hline 1988 & 200 & 5 & 3 & 10 & 18 & 0 & 5 & 15 & 6 & 26 & 192 \\
\hline 1989 & 192 & 3 & 2 & 0 & 5 & 0 & 0 & 3 & 24 & 27 & 170 \\
\hline 1990 & 170 & 22 & 0 & 3 & 25 & 0 & 1 & 3 & 0 & 4 & 191 \\
\hline 1991 & 191 & 24 & 8 & 14 & 46 & 0 & 2 & 6 & 1 & 9 & 228 \\
\hline 1992 & 228 & 2 & 0 & 1 & 3 & 0 & 0 & 0 & 0 & 0 & 231 \\
\hline 1993 & 231 & 16 & 1 & 0 & 17 & 0 & 0 & 16 & 0 & 16 & 232 \\
\hline 1994 & 232 & 2 & 0 & 4 & 6 & 2 & 68 & 1 & 22 & 93 & 145 \\
\hline 1995 & 145 & 0 & 0 & 0 & 0 & 0 & 0 & 0 & 0 & 0 & 145 \\
\hline 1996 & 145 & 1 & 3 & 2 & 6 & 0 & 0 & 2 & 0 & 2 & 149 \\
\hline 1997 & 149 & 15 & 3 & 0 & 167 & 0 & 0 & 8 & 0 & 0 & 159 \\
\hline 1998 & 159 & 10 & 7 & 0 & 166 & 2 & 0 & 12 & 18 & 46 & 134 \\
\hline 1999 & 134 & 22 & 0 & 0 & 156 & 5 & 0 & 0 & 0 & 5 & 151 \\
\hline 2000 & 151 & 7 & 5 & 0 & 163 & 1 & 5 & 8 & 0 & 14 & 149 \\
\hline
\end{tabular}




\section{APPENDIX B}

\section{PRAYER AND PERSONAL BIBLE STUDY SURVEYS}

\section{Pre-Project Survey about Prayer}

1. Do you feel the need to pray?

ONever. OSometimes. OOnly in church. OAt meals. OFrequently.

2. How important is prayer in your life?

OUnimportant. (I don't know. OSometimes it is important. OVery important.

3. How many times a day do you pray?

()I don't pray daily. OI don't know. ()1 time. (When I eat and go to bed. (05 times. OMore than 10 times.

4. Do you believe that prayer is important for your spiritual growth?

OI don't believe so. OI don't know. OSometimes. OExtremely important.

5. Do you believe that a seminar on how to pray more effectively is necessary?

OI don't believe so. OI'm not sure. OSometimes. OExtremely important.

\section{Pre-Project Survey about Personal Bible Study}

1. How often do you feel the need to study the Bible for spiritual growth?

ONever. OSometimes. OOnly in church. (When there are problems. OFrequently. 
2. How important is personal study of the Bible for you?

OUnimportant. OI don't know. ()Sometimes it is important. OExtremely important.

3. How much effect does study of the Bible have on your spiritual growth?

()No effect. (I don't know. ()Sometimes. (It has much effect.

4. Do you believe that a seminar on personal study of the Bible is necessary?

OI don't believe so. OI'm not sure. OExtremely important.

5. How many times per week do you read your Bible?

()I don't read it. OOnly in church. ()2 times. (03 times. (05 times. OMore than 5.

\section{Post-Project Survey about Prayer}

1. Do you feel the need to pray?

ONever. OSometimes. (O)nly in church. OAt meals. OFrequently.

2. How important is prayer in your life?

OUnimportant. OI don't know. OSometimes it is important. OVery important.

3. How many times do you pray every day?

OI don't pray. OI don't know. O1 time. OWhen I eat and sleep. OFrequently

4. Do you believe that prayer is important for your spiritual growth?

OI don't believe so. OI don't know. OSometimes. OExtremely important.

5. Do you think that the seminar helped you to improve your program of personal prayer?

OI'm not sure. OIt did not help me. OYes, it helped me. 


\section{Post-Project Survey about Personal Bible Study}

1. How often do you feel the need to study the Bible for spiritual growth?

ONever. OSometimes. ()Only in church. OWhen there are problems. ()Frequently.

2. How important is personal study of the Bible for you?

OUnimportant. OI don't know. OSometimes it is important. OExtremely important.

3. How much effect does study of the Bible have on your spiritual growth?

ONo effect. OI don't know. OSome effect. OIt has much effect.

4. How many times during the week do you study your Bible?

OOnly in church. ONever. (02 times. (03 times. (05 times. OMore than 5.

5. Do you think that the seminar helped you to improve your study of the Bible?

OIt did not help me. OI am not sure. (OYes, it helped me. 


\section{APPENDIX C}

\section{SURVEY RESULTS (RAW DATA)}

\section{Pre-Project Survey Results}

Prayer

Question 1:

Never

4

Sometimes

At meals

15

Frequently

30

Just in church

7

Question 2:

Very important

71

Sometimes

25

I don't know

8

Question 3:

Never pray

I don't know

1 time/day

When I eat and at bedtime 29

More than 3

30

More than 5

Question 4:

Sometimes

15

I'm not sure

13

Extremely important

Question 5:

I don't know

1

I'm not sure

15

Extremely important 
PBS

Question 1: $\quad$ Never 10

Only in church 8

Sometimes 52

When I have problems $\quad 14$

Frequently 20

Question 2: $\quad$ Not important 1

I don't know 3

Sometimes it's important $\quad 46$

Extremely important 54

Question 3: $\quad$ Much effect $\quad 74$

Sometimes 22

I don't know 7

Any effect 1

Question 4: $\quad$ Not necessary $\quad 0$

I'm not sure $\quad 18$

Extremely important $\quad 86$

Question 5: $\quad$ Only in church 25

I never read it $\quad 10$

2 times $\quad 30$

3 times $\quad 12$

5 times $\quad 15$

More than 5

\section{Post-Project Survey Results}

Prayer

Question 1:

Never

Sometimes

0

At meals

Just in church

Frequently

Question 2: $\quad$ Very important $\quad 75$

Sometimes 3

I don't know

Question 3: $\quad$ Never pray $\quad 0$ 
I don't know 2

1 time 12

Meal and bed times 5

Frequently 60

Question 4: $\quad$ Sometimes 2

I'm not sure 2

Extremely important 75

Question 5: I'm not sure $\quad 2$

It doesn't help me 2

It helps me 75

PBS

Question 1: $\quad$ Never 0

Only in church 2

Sometimes 12

When I have problems 5

Frequently 63

Question 2: $\quad$ Not important $\quad 0$

I don't know 0

Sometimes important 11

Extremely important $\quad 71$

Question 3: $\quad$ Never pray 0

I don't know 2

1 time 12

Meal and bed times 5

Frequently 60

Question 4: $\quad$ Sometimes 2

I'm not sure 2

Extremely important $\quad 75$

Question 5: I'm not sure 2

It doesn't help me 2

It helps me 75 


\section{APPENDIX D \\ OUTLINE OF WEEK OF PRAYER SERMONS}

\section{First Saturday: Spiritual Growth Through the Word}

INTRODUCTION: "Do not let this book depart from your mouth; meditate on it day and night, so you may be careful to do everything written in it. Then you will be prosperous and successful" (Josh 1:8). These words were spoken to Joshua just after Moses' death, on the bank of the Jordan River at the door of Canaan. Joshua had to assemble the people of Israel and organize them to conquer and take possession of the Promised Land.

I. God ordered Joshua to meditate on the book day and night. At the time of Joshua only the Pentateuch existed. According to Deut 31:24-26, these sacred books were set out at the side of the Ark in the Holy of Holies. The five books of Moses had all the elements they needed to be spiritually fed. Joshua and the Israelites could not forget the words of the book if they wanted to be successful in the promised land.

II. What did God ordain with the book? The command given by God was to meditate. It was not a simple reading. What did the word meditate mean? The Hebrew word for meditate has many implications: to murmur, to think, to meditate, to speak, to reflect, to seek, to study, to recite aloud, to rehearse, to go over a matter. 
When a Hebrew person meditated, he/she renewed his/her spiritual strength (Ps 19:14). God told Joshua that his priority should be to meditate on the law. The new cultural setting would provide a busy task, extra work hours, very tight schedule. Conquering the Holy Land would require a lot of effort and dedication on his part. God specifically told him never to forget to study the law.

III. What practical lessons does this passage teach us? The society in which we live demands a lot of effort from each of us simply in order to survive. The command of God is the same today. He ordered us, if we want to be successful in this world, to meditate on His revelation. No matter how busy we are, we must not forget to read His word.

\section{Sunday: Lord Teach Us to Pray}

INTRODUCTION: "One day Jesus was praying in a certain place. When he finished, one of his disciples said to him, 'Lord, teach us to pray, just as John taught his disciples"' (Luke 11:1). The disciples felt their prayer was a routine. When Jesus prayed, they noticed a true relationship with God. The way Jesus prayed was uncommon among the spiritual leaders of that day. He seemed to be conversing with His father. The prayer of Jesus motivated them to ask, "Teach us to pray, just as John taught his disciples." The question of the disciples is valid today to modern Christians. The prayer of Jesus still should be learned today. What does the Lord's Prayer teach us today?

I. Concept of prayer during Jesus' time. Prayer in Jesus' time was in a period of decadence. In the OT prayer in Psalm and the prophets was a dialogue between God and the penitent. The Jews of the time of Christ were trained in the old fashioned tradition of 
the midrash and targumim. Regretfully, by the time of Jesus prayer, prayer in Jewish circles had degenerated to the point where it became meaningless to the person who prayed. Jesus did not introduce a new paradigm in prayer. He followed the patterns of the OT. The disciples saw prayer as an urgent need not necessarily as a suitability of the age (Matt 6:5-7).

II. Luke 11:2-4 is the shortest version of the Lord's Prayer. This model prayer must be studied in the dimension of the time: past, present, and future. The Lord's prayer recognizes that there is no other God. The penitent expects the future kingdom. He/she says "your kingdom come." The craving of each true disciple is to achieve eternity by the grace of Jesus (Rom 8:22-23). The Lord's Prayer teaches the true disciple to be aware of the present in this way "give us this day our daily bread." In a consumer society it is hard to apply the principle of asking God for our daily bread because humans are never satisfied with the objects they obtain. The present is fleeting. God wants us to focus on eternal matters ( 2 Cor 4:18). The Lord's prayer teaches us about the past "Forgive our sins, for we also forgive everyone who sins against us." This section is grounded in the sacrifice of Christ on the Cross. Every time we ask God for forgiveness, we in turn see Jesus dying for our sins. The Lord's Prayer teaches us that our past started when we accepted the death of Christ. We have a new beginning. We can forgive because we have understood and experienced the forgiveness of Christ.

III. What implications does the Lord's Prayer have for our times? The Lord's prayer teaches us to totally dependent upon God for the present, past, and future. We must not just memorize the Lord's Prayer. It is important to apply these principles to our 
prayer lives. Spurgeon once said "The power of prayer can never be overrated. Those who cannot serve God by preaching need not regret. If a man cannot pray, he cannot do anything."1

\section{Monday: Finding Joy in the Anguish Through His Word}

INTRODUCTION. "When your words came, I ate them; they were my joy and my heart's delight, for I bear your name, O Lord God Almighty" (Jer 15:16). The age we live in is full of pressures, anxiety, stress, and other problems. Gary Collins said, "Struggle is a universal experience and most of us feel insecure at least periodically." The experience that Jeremiah the prophet went through is quite similar to our vicissitude in the post-modern times. The purpose of this sermon is to find joy in the word of God as the prophet Jeremiah did.

I. During his ministry Jeremiah suffered persecution. He was despised by his own people. Jer 37 presents the torture inflicted to him by its leaders. In the middle of opposition he entered into a state of anxiety. Jer 16:15 presents the whole picture of his intense suffering, loneliness, anxiety, depression, and hopelessness (Jer 19:9). He did not want to know any more about God.

II. In Jer 15:16, the whole picture changes. He has promised himself in his anguish not to follow the Lord. In his loneliness he turned again to the word of God, and after he experienced reading, he said "When your words came, I ate them, they were my

${ }^{1}$ Charles Spurgeon, quoted by Dwight Nelson, Power of Prayer (n.p, n.d.), 1.

${ }^{2}$ Gary Collins, Christian Counseling (Dallas: Word Pub., 1988), 63. 
joy and my heart's delight for I bear your name, O Lord God Almighty" (Jer 16:15).

The word of God brought him hope and strength. His anxiety and depression disappeared.

III. Today we can learn several lessons from his experience. Christians today live under pressure. Contemporary society imposes stress. Modern Christians must look for the word of God in order to overcome stressful situations. Regretfully, many Christians instead of looking to the word of God for relief of the burdens of life, look for other methods which do not help them to solve their problems. Paul advises in 1 Thes 2:13 that one observe the effects of the word of God. The individual who enters in touch with it will be energized. The word of God can help us today when we are going through hard times as it helped Jeremiah in his hard times.

\section{Tuesday: Ascending to God's Throne}

INTRODUCTION: "May my prayer be set before you like incense, May the lifting of my hands be like the evening sacrifice" (Ps 141:2). Ellen White asserts, "Prayer does not bring God down to us here on earth, but prayer ascends us to Him." When an individual prays by faith, he/she is in a personal encounter with the Eternal before His throne. Prayer is a confluent in heaven, where the temporary man meets with the everlasting God. The whole universe is aware of that meeting.

I. Ellen White says that this Psalm was written by David after the incident of Nabal. The scholars classified this as a petition psalm. The individual who prayed was

\footnotetext{
'White, Steps to Christ, 92.
} 
going through a hard time, and in this episode he asked God for help. This Psalm presents the real concept of prayer: the person who prays is in true conversation with God. Prayer is compared to the incense burnt during the evening sacrifice.

II. Analysis of Ps 141. This Psalm could be a private or communal prayer. The individual seems to have developed a close relationship with God. If David was the writer, he is experiencing a time of persecution. In his distress he calls out to God. When he prays the situation changes. In vs. 2 he seems to be in a sweet conversation with God. He compares his prayer with the evening sacrifice (Exod 30:6-7). The incense was burned inside the holy place, and the incense went over the curtain to the Most Holy place. Incense in the biblical setting refers to prayer $(\operatorname{Rev} 5: 8,8: 3)$.

III. The meaning of prayer is the same as it was during the biblical times. When we pray our prayers ascend to the throne of God. We can also enter into a sweet conversation with God before his throne by faith, and all the universe can watch that meeting. Stressful situations can move us away from prayer, but we must follow the example of David. Through prayer he changed his desperate situation into joy because when he prayed he was introduced into the presence of God through the merits of Jesus. We as Christians can experience the same joy today if we converse with God through prayer.

\section{Wednesday: Spiritual Nurture Through His Word}

INTRODUCTION: "Now the Bereans were of more noble character than the Thessalonians, for they received the message with great eagerness and examined the scriptures every day to see if what Paul said was true" (Acts 17:11). The Bereans are a 
model for searching the scriptures. These members of the Early church studied the scripture in a profound way. The Bereans were not satisfied with the things they heard. What they heard they confirmed with diligent personal study of the scriptures on their own. Theirs is a good lesson for us to learn today.

I. Berea was located in Macedonia. It belonged to ancient Greece, but in time of Paul it was under Roman government. At that time the only scriptures were the OT. Paul preached about the acts of Jesus, so the Bereans searched the OT to see if what Paul said about the Messiah was confirmed there.

II. Vs. 11 says, "The Berean people were eager." They had an intense desire to know more about the scriptures. The Bereans did not act out of emotion. The Bible says they studied the scriptures daily. They were aware that the scriptures not only confirmed the deeds of Christ but also filled their spiritual needs. The study of scriptures kept them alive spiritually. The word used for search is to inquire, analyze the evidence. It was the same word used for a judge in the court when he examines the evidence.

III. Today we live in an age of superficiality. People just believe what they hear in church. The example of the Bereans should be taken into consideration. We need to search every sermon. Everything we read must be compared with the scriptures. If we do this on a daily basis, we can obtain the following: (1) We can nurture ourselves with the word of God, (2) We will not be deceitful as we share with others. It is important to return to the Berean paradigm to prove everything by the scriptures. 


\section{Thursday: Along with God Through Prayer}

INTRODUCTION: "One of these days Jesus went out to a mountainside to pray, and spent the night praying to God" (Luke 6:12). Contemporary society imposes so many responsibilities on us that it seems impossible to seek God for a few minutes each day in prayer. Regretfully, the discipline of prayer has been abandoned and it is scarcely practiced among Christians today. A well known writer expresses the idea that the neglect of prayer by the church is the greatness reason for its powerlessness. ${ }^{1}$ The life of Christ is a great example for us today regarding prayer. In his time Jesus frequently prayed.

I. In this incident Jesus was praying alone in a solitary place. Prayer was vital for His life and ministry (Mark 1:35, Luke 3:21). Jesus chose solitary places to be in communion with God. For Jesus, prayer included both talking with His father and listening to Him in moments of silence (Ps 37:7, 83:1).

II. A great decision was about to take place. Jesus needed the assurance of His father to call the 12 disciples. Luke 6:13-16 narrates the story of the calling of the 12 disciples. Jesus was choosing the new leaders of the nascent church, so he spent the whole night in prayer. Every time Jesus prayed, He looked for God's will. The decision He made at that moment depended on the approval of His father. The elected ones needed power to fulfill the mission. They needed to understand God's plan regarding Jesus and the foundation of the new church.

${ }^{1}$ Duewel, 34. 
III. We Christians must learn from the life of Jesus. We fail in our decisions because we do not take God into consideration. Eph 6:18 commands every Christian to continually to pray. A person that prays is not empty but full of God. In prayer we must hear God's voice instead of human noise. We must start a consistent prayer plan in our daily lives. The defense against Satan's assaults in this time is commitment to Jesus through prayer.

\section{Friday: Spiritual Daily Strength Through the Word}

INTRODUCTION: “And how from infancy you have known the Holy Scriptures, which are able to make you wise for salvation through faith in Christ Jesus" (2 Tim 3:16). The study of the Bible is compared with the daily food. We need daily food to nurture ourselves to grow up-vitamins and minerals to build up our bodies. If we do not eat we will stunt our physical growth and we will get weak and finally we will die. The study of the Bible provides us with what we need for spiritual growth.

I. Timothy was a bishop of Ephesus when Paul wrote him a letter. Apparently Timothy came from a non-Jewish father and a Jewish mother. In the second missionary trip of Paul, his family accepted the Good News (Acts 14:20). His mother and grandmother took care of his spiritual education. They followed Jewish tradition in the education of Timothy. A characteristic of Jewish education was teaching the scriptures to every child. They knew that the study of scriptures would help the child to develop spiritually.

II. "I have been reminded of your sincere faith, which first lived in your grandmother Lois and in your mother Eunice and, I am persuaded, now lives in you" (2 
Tim 1:5). Later in the same book, Paul reminded him that, "From infancy you have known the scriptures" (2 Tim 3:15). Timothy nurtured himself with the word of God from his childhood (Prov 1:8). The study of scriptures made him wise, and strengthened him spiritually. Timothy knew the value of scriptures for his spiritual diet. The study of the word equipped him to be a good leader and to do the good work.

III. We humans need a complete diet to survive in the physical world. The analogy is that we need spiritual food to survive spiritually. We need to feed ourselves with the word of God. The scriptures will help us in our spiritual growth. 1 Thes 2:13 says, "And we also thank God continually because, when you received the word of God, which you heard from us, you accepted it not as the word of men, but as it actually is, the word of God, which is at work in you who believe." The individual who feeds on the Word of God gets spiritual energy so that he/she can survive in this world.

\section{Second Saturday: What "Praying in The Name of Jesus" Means}

INTRODUCTION: "In that day you will no longer ask me anything. I will tell you the truth, my Father will give you whatever you ask in my name. Until now, you have not asked anything in my name. Ask and you will receive, and your joy will be complete" (John 16:23-24). Since Jesus established His church, every Christian has prayed in his name. In the NT, Jesus did not teach a new way for praying, he only added one element, His name.

I. John 14 is a new section of the book. In this segment Jesus talked alone with his disciples except for Judas. Jesus seems to be dismissing himself from his disciples. He clearly promises them, "I will not leave you orphans" (John 14:18). The disciples were 
disappointed to hear of Jesus' departure. Jesus promised them the Holy Spirit, but he also promised them his personal presence. How would they sense Jesus' presence without his physical appearance?

II. Jesus told them, "You may ask me for anything in my name, and I will do it" (John 14:14). What is the meaning of "ask everything in my name"? There are two possible meanings: His abiding presence, and His permanent intercession. In the OT, "name" means "permanent presence" (Exod 34:14). To pray in His name was to have the assurance of his permanent presence. To pray in his name is to recognize his intercession. Prayer would take them to the Holy Sanctuary to the presence of God. They knew, they were in the presence of the Lord for the intercession of Jesus.

III. Modern society has blurred the presence of God from our lives. God must be seen as a person not as a force. When we pray today in the name of Jesus we also recognize his merits, his intercession, and his permanent presence. The absence of Christ in the soul keeps us away from prayer. 
APPENDIX E

SEMINAR ADVERTISEMENTS AND MATERIALS

HUMBOLDT PARK CHURCH

1733 N KEDVALE CHICAGO, IL 60639

PHONE (773) 235-0758

WELCOME TO THE SEMINAR

ON PERSONAL PRAYER

DECEMBER $4^{\mathrm{TH}}$ AND $5^{\mathrm{TH}}, 1998$

FRIDAY FROM 7:00 TO 9:30 P.M.

SATURDAY FROM 3:00 TO 6:30 P.M.

HUMBOLDT PARK CHURCH

1733 N KEDVALE CHICAGO, IL 60639

PHONE (773) 235-0758

WELCOME TO THE SEMINAR

ON PERSONAL BIBLE STUDY

DECEMBER $11^{\mathrm{TH}}$ AND $12^{\mathrm{TH}}, 1998$

FRIDAY FROM 7:00 TO 9:30 P.M.

SATURDAY FROM 3:00 TO 6:30 P.M. 


\begin{abstract}
APPENDIX F
PRACTICAL INSTRUCTIONS FOR PRAYER AND BIBLE STUDY
\end{abstract}

\title{
Prayer
}

Due to the sui-generis environment in which HPHC members live, the following program could be accommodated to whatever time and place works best for each individual. The following suggestions must be fulfilled in order to attain complete success:

1. Find time to pray. Review your daily schedule. Visualize your priorities. Once you have a whole picture of your daily assignments, reschedule all your activities and leave room "for unhurried prayers." It is important to find adequate time to pray effectively. ${ }^{2}$ You can start with five minutes every day and expand your time as you become accustomed to prayer life. Tell your family that you will be praying. Do not attend to anything during this time of prayer unless an emergency arises. Remember that Satan seems to able to manipulate circumstances or people

${ }^{1}$ Deuwel, 103.

${ }^{2}$ Engelkemier, 30 Days, 58. 
to interrupt. ${ }^{1} \quad$ Everett Cattell asserts that "successful prayer cannot be measured by the clock - it must rather be measured in terms of unhurriedness."2

2. Find a place to pray. Remember that lack of concentration can baffle your prayers. A fixed place will help you to concentrate when you pray. Remember that prayer "means that we address ourselves to God, who has already spoken to us in the Gospel and in the law. We find ourselves face to face with him."

3. Be consistent. If you fail do not give up. Remember we learn from mistakes. Try again. Wesley Duewel believes that "the greatest need of God today is for men and women who know how to prevail in prayer - mighty intercessors, tireless prevailers, people who will prevail in prayer battle and prayer." ${ }^{\text { }}$ One thing is important to take into consideration, "We must begin where we are."

4. Personal prayer is synonymous with solitude. Phillip Samaan state, "In this bewilderingly distracting world, it seems virtually impossible to be alone."6 Prayer in the biblical sense is to spend time alone with God. Richard Foster affirms,

${ }^{1}$ Deuwel, 54.

${ }^{2}$ Everett L. Cattel, The Spirit of Holiness (Grand Rapids, MI: Wm. B. Eerdmann's Pub. Co., 1963), 67.

${ }^{3}$ Barth, 31 .

${ }^{4}$ Deuwel, 22.

${ }^{5}$ Richard Foster, Prayer: Finding the Heart's True Home (San Francisco: Harper Collins Pub., 1992), 11.

${ }^{6}$ Samaan, 116. 
"Jesus calls us from loneliness to solitude.' In His daily life, Jesus, in spite of His tight schedule, "often retreated to a quiet place to pray." Mark records an incident of the life of Christ: "Very early in the morning, while it was still dark, Jesus got up, left the house and went off to a solitary place, where he prayed" (Mark 1:35). Regretfully, in today's society, "the idea of being alone petrifies people." $T$ To be alone in prayer means inner fulfillment. ${ }^{4}$ If one spends time with God daily, then prayer will be "an experience." If we spend time alone with God, we will be ready to serve people. The goal of retreating for prayer is not to be apart from people but to gather strength to be among people.

5. Be specific. Make a list beforehand of the things you want to present before God. When you pray, do not repeat the same things. This was a pagan custom which must be excluded from Christian prayer. Jesus says, "And when you pray, do not keep on babbling like pagans, for they think they will be heard because of their many words" (Matt 5:7). Although God knows everything, you must be specific in your request. Ellen White believes that we do not inform God when we pray because he knows everything before we ask, but the plan of God is to concede us

${ }^{1}$ Foster, Celebration, 96.

${ }^{2}$ James B. Smith, A Spiritual Formation Workbook (San Francisco: Harper Collin Pub., 1993), 21.

${ }^{3}$ Foster, Celebration, 96.

${ }^{4}$ Ibid.

${ }^{5}$ Ellul, 100. 
the things he thinks are best for us. Keep these words in mind: "I waited patiently for the Lord: he turned to me and heard my cry" (Ps 40:1).

6. Focus on God, not on yourself. A well-known scholar believes that "to come near to God is to change."1 When true prayer occurs, the devoted Christian notices that he/she cannot pray one way and live another. ${ }^{2}$ When a person prays, he/she is before the king of the universe. What is man before the God of the universe? Job declared many years ago, "My ears had heard of you, but now my eyes have seen you. Therefore I despise myself and repent in dust and ashes" (Job 42:5-6).

Douglas Steere quoted Emily Herman regarding man before God in prayer: "If my prayer is real, my surface self, my ego, my persona, must decrease and he must increase in me."3 Personal prayer in solitude focuses only on God. Although man feels miserable he knows he is not insignificant because the merits of Christ let him/her come before the throne of God. Luther believes that prayer is "a climbing up of the heart unto God."4 The incomprehensible richness of prayer is to watch a feeble creature face to face with the omnipotent creator of the heavens and the earth in a sweet conversation before the whole universe. His everlasting presence

${ }^{1}$ Steere, 33.

${ }^{2}$ Judith Lechman, The Spirituality of Gentleness: Growing Toward Christian Wholeness (San Francisco: Harper \& Row Pub., 1987) 39.

${ }^{3}$ Steere, 33 .

${ }^{4}$ Richard Foster, and James B. Smith. Devotional Classics (San Francisco: Harper Collins Pub., 1989), 135. 
takes hold at the time of prayer. The future breaks into the present with the presence of God when an individual prays. ${ }^{1}$

7. Pray intensely to know the will of God. You should pray to know the will of God, but you have to pray also to accept the will of God. Remember the words of Jesus when he prayed in Gethsemane: "Going a little farther, he fell with his face to the ground and prayed, 'My Father, if it possible, may this cup be taken from me, yet not as I will, but as you will"' (Matt 26:39). The more an individual prays and studies the Bible, the more he/she will perceive the will of God. Brian Dodd concludes that to understand God's will is to align ourselves in submission to Jesus. $^{2}$

8. Make a habit of listening to the voice of God. The book of Psalms recommends, "Be still before the Lord and wait patiently for him" (Ps 37:7). Remember that prayer is bilateral: you talk and God listens, then God speaks and you listen. Every time you finish praying, you must wait in silence for the voice of God. The Lord will impress you if you listen for His voice in silence. Judith Lechman asserts that by "listening to God in silence, you will receive insight, guidance, redirection, and new effectiveness in living your life." At the beginning, it will be difficult to listen God's voice because you have not done it before. You will listen to other

'Paul DeBlaissie, Deep Prayer Healing for the Hurting Soul (New York: Crossroad Pub. Co., 1990), 108.

${ }^{2}$ Brian J. Dodd, Praying Jesus' Way (Downers Grove, IL: Intervarsity Press, 1967), 76.

${ }^{3}$ Lechman, 37. 
voices inside of you rather than God's voice. "Prayer makes us hear all our noises." If this happens, please do not give up; remember that a continual act is transformed into a habit. Persist in praying to God, telling Him that you want to listen to His voice in silence. After a while, by the grace of God, you will recognize His voice. Prayer teaches a lesson: if God listens patiently for our prayers, we must wait patiently for his voice. ${ }^{2}$ Remember that "waiting is the ability to be still in order to discern God's presence."3

9. Pray Bible prayers. Learn psalms and other texts by heart. Dorothy Watson believes that biblical images should emerge at the time of prayer. ${ }^{4}$ Forming Bible images in the mind can help the person to be totally absorbed at the moment of praying. Retrieving biblical portraits at the moment of prayer empowers the mind. ${ }^{5}$ The prayers in the book of Acts are full of OT allusions, and it seems that the apostles were utterly immersed in sacred history. ${ }^{6}$

10. "Pray continually" (1 Thess $5: 17)$. The Early Christians took this admonishment seriously; they knew by experience the importance of constant prayer. "And pray

${ }^{1}$ Ulanov, 51.

${ }^{2}$ Lall, 5.

${ }^{3}$ DeBlaissie, 90.

${ }^{4}$ Dorothy E. Watts, Prayer Treasures: Discover the Riches of Prayer (Boise, ID: Pacific Press Pub. Assn., 1995), 28.

${ }^{5}$ Keiper, 13-14.

${ }^{6}$ Bonnie Thurston, Spiritual Life in the Early Church (Augsburg, MN: Fortress Press, 1993), 58-59. 
in the spirit on all occasions with all kind of prayers and requests. With this in mind, be alert and always keep on praying for all the saints" ( 2 Thess $1: 11$ ). When prayer becomes a discipline in the life of a devoted Christian, personal prayer transforms the attitude of the mind. Douglas Steere believes that "if we love God, if we acknowledge joyfully to whom we belong, if, in our intervals between other tasks, this love moves naturally to the surface and gives a glow to all that we do, this is prayer without ceasing, perpetual prayer,"1 Ellen White points out this fact beautifully: "It is not necessary to bow upon our knees to pray. Cultivate the habit of talking with the Savior when you are alone, when you are walking, and when you are busy with daily labor." ${ }^{2}$ She suggests that every breath should be a prayer. ${ }^{3}$ When a person has an attitude of prayer, the position is not important before God. Richard Foster believes that prayer without ceasing is to experience the presence of God all the time. This way one can have a close communion with Him. ${ }^{4}$

\section{Personal Bible Study}

These practical instructions will help HPHC members to start a PBS program. This program can be adapted to HPHC members according to their needs. As was

${ }^{1}$ Steere, 93.

${ }^{2}$ Ellen White, The Ministry of Healing (Mountain View, CA: Pacific Press Pub. Assn., 1956), 510-11.

${ }^{3}$ Ibid., 512.

${ }^{4}$ Foster, Prayer, 124. 
discussed among the members during the PBS seminars, there is not specific time for studying the Bible. The time and environment in which every member lives is different from each other.

To start a program of personal Bible study, these suggestions should be taken into consideration for successful beginning:

1. Choose a place. It is important to choose a place for studying the Bible. Try to be consistent with your choice of location every time you read the Bible. If you choose a different place every day, you will be distracted by the environment. Remember every time you change place, you will be captivated by the surroundings. If you have a steady place, it will be easy to concentrate. You will not pay attention to the little details of the environment. Choose a place where you feel comfortable.

2. Decide how long are you going to nurture yourself. It can be $10,15,30,45$ minutes or 1 hour. Choose a time when no one will disturb you. The time can be in the morning, noon, evening, or late at night, depending on your work schedule. Be persistent. Tell the people around you that you will be studying the Bible for that time. Do not do anything else except in an emergency.

3. Pray before opening the Bible. Remember what Andrew Murrey says: "Prayer and the word are inseparably linked together: power in the use of either depends upon the presence of God." Remember that sincere prayer prepares the heart to receive

${ }^{1}$ Murray, The Inner Life, 22. 
the word of God. ${ }^{1}$ When you pray ask God for the direction of the Holy Spirit, and do not forget the words of Jesus, "But when He, the Spirit of truth, comes, he will guide you into all the truth" (John 16:13). Prayer conditions you to enter into an intimate relationship with God. ${ }^{2}$ When you open the Bible, the atmosphere prepares you to listen to God's voice through PBS. Ellen White says, "Never should the Bible be studied without prayer. Before opening its pages we should ask for the enlightenment of the Holy Spirit and it will be given"3 If a person reads the Bible without praying, he/she can be Bible taught but not spirit taught. ${ }^{4}$

4. Pick a passage, a text, a psalm, a miracle, a story, or a chapter. This could be chosen before praying. If you pick a portion just for information and not for spiritual nurture, pretty soon your PBS will become stale. ${ }^{5}$ If you choose a Bible passage, you should delight in it. Samaan suggests, "The first thing to do is to select a suitable passage describing an incident in which God encounters people." Read as much as you can of the Bible passage which you have chosen.

\section{${ }^{1}$ Ibid.}

${ }^{2}$ The Kneeling Christian (Barcelona, Spain: Talleres Gráficos de la M.C.E. Horeb, 1987), 63.

${ }^{3}$ White, Steps to Christ, 91.

${ }^{4}$ Watson, 102.

${ }^{5}$ Hans R. Weber, The Bible Comes Alive: New Approaches for Study Groups (Valley Forge, PA: Judson Press, 1996), 53.

${ }^{6}$ Samaan, 147. 
5. Cogitate or ruminate on the Bible passage you have chosen. If you do this, pretty soon you will be mentally grown up. ${ }^{1}$ After you read the passage several times and meditate on it, you will be ready to concentrate on the part which you are studying for the day. Some helpful ways to meditate on the Bible passage are:

F. Think iconographically. Because the mind is shaped by the social patterns of the community in which the members live, it is difficult to form Bible images in the mind without studying them. To think iconographically is to open a window in our minds and enlarge it by meditating on that portion. When concentrating on the biblical scene, Mulholland believes that, "if we begin to see the scriptures iconographically, automatically we begin to move into the formation mode." ${ }^{2}$ The individual must appropriate a Bible passage, he/she must be part of it. Todd Temple advises that a student of the Bible must look for God's self portraits. ${ }^{3}$ Reading the Bible and looking for images to shape the mind with them will make the study of the Bible more enjoyable. ${ }^{4}$ 18.

${ }^{1}$ Henry M. Morris, Explore the World! (San Diego: Creation-Life Pub. Inc., 1978),

${ }^{2}$ Mulholland, 66 .

${ }^{3}$ Todd Temple, 21 Days To Enjoying Your Bible (Grand Rapids, MI: Zondervan Pub. House, 1998), 19.

${ }^{4}$ Ibid. 
G. Enhance your biblical scene by reading the rest of the chapter or book and also by consulting a Bible dictionary, a concordance, or some portion of Ellen White's writings which relate to that Bible passage.

H. Try to paraphrase the reading by forming images in your mind.

I. Apply the Bible passage to your life. Carole Mayhall says, "Remember, the most important part of any study is applying it."1

J. Think about this passage during the day. Keep shaping your mind with the biblical scenes.

K. Write down how that passage helps you to overcome temptation, solve a problem, or become spiritually stronger.

L. Talk about the passage with church members and with unchurched people as well.

6. Make a habit of listening to God's voice through his Word. God speaks differently to each individual. Everyone must learn to discern God's voice through the passage chosen on that day. Judith Lechman points out, "God also speaks to us in ways other than scriptures. His guiding hand can be felt in the devotional." Pray before concluding your Bible study for the day.

${ }^{1}$ Carole Mayhall, Come Walk With Me (Colorado Springs, CO: Water Brook Press, 1992), 25. 


\section{APPENDIX G}

\section{TRANSLATION OF HANDOUTS}

\section{Seminar on Prayer}

Instructor: Julio Juárez

Phone: (708) 484-5170

Email:

\section{SEMINAR DESCRIPTION}

This course intends to provide to the participants the necessary tools for beginning and maintaining a daily prayer life.

II. METHODS OF INSTRUCTION

Subject areas from description outline will be addressed through lectures, group discussion, transparencies, and slides.

III. GENERAL OBJECTIVE

Participants will be able to understand the role of prayer in their devotional lives.

IV. SPECIFIC GOALS

1. They will be able to plan a strategy for daily prayer.

2. They will be able to comprehend the importance of having a daily schedule.

3. They will be able to repeat Bible prayers in their minds during the day.

4. They will be able to keep an attitude of prayer throughout the day and night.

\section{OUTLINE OF THE COURSE}

Review of the selected portion of the Bible for prayer in:
A. The Old Testament
B. The New Testament 
Analysis of Hebrew and Greek terms:

A. Hebrew Terms, Old Testament

B. Greek Terms, New Testament

Planning a Personal Prayer Strategy

1. Importance of finding a time to pray.

2. A place for prayer is essential.

3. Be consistent. This is the secret of a victorious spiritual life.

4. Seek for solitude. Make this time for companionship with God.

5. Learn to be specific.

6. Determine to focus on God, not on yourself.

7. Assimilate God's will.

8. Make a routine to listen to God's will.

9. Repeat Bible prayers.

10.Make it a habit to pray continually.

\section{REQUIREMENTS}

There are no excuses for participants if they missed a session.

Participation is important both in group discussion and during the lectures.

It is important to read extra materials and handouts.

\section{BIBLIOGRAPHY}

Engelkeimer, Joe. 30 Days to a More Powerful Prayer Life. Nanpa, ID: Pacific Press Pub. Assn, 1998.

Engelkeimer, Joe. Whatever It Takes Praying: How Our Yes to What God Asks Brings His Yes to What We Ask. Fallbrook, CA: Hart Research Center, 1993.

Foster, Richard J. Celebration of Discipline: The Path to Spiritual Growth. San Francisco: Harper Collins Pub., 1978, pg. 33-46.

Foster, Richard J. Prayer: Finding the Heart's True Home. San Francisco: Harper Collins Pub., 1992.

Maxwell, John. Partner in Prayer. Nashville: Thomas Nelson Pub., 1996.

Saaman, Philip. Christ's Way to Spiritual Growth. Hagerstown, MD: Review \& Herald Pub. Assn., 1995, pg. 115-129. 


\section{Handout 1}

Prayer in the Old Testament was not a matter of reciting long phrases but rather it was a time of sweet communion with God. Psalms 32:6. Psalms 72:15.

The Hebrew term חלה means "to be contrite, be empty, cover with dust, to be sick."

For the Hebrew of the Old Testament prayer was an attitude.

The book of Psalms is called the prayer book.

Ancient Israelites believed that prayer was an encounter between God and his creatures in heaven.

Prayer was a way to be acquainted with God's will.

Prayer is two-way communication: the creature speaks and God hears, and God speaks and the creature hears.

\section{Handout 2}

The Greek term $\pi \rho \circ \sigma \varepsilon \cup \chi \eta$ means to pray.

The New Testament does not teach a new way of praying.

Jesus followed the patterns of the old prophets and of the book of Psalms during his ministry.

Jesus taught his disciples to ask everything in his name.

For the first Christians to know the name of Jesus meant to know his character.

For the first Christians to pray in the name of Jesus meant to accept his intercession.

For the Early Church to pray in the name of Jesus meant to accept his presence.

The early Christians prayed to experience the presence of Jesus in their lives.

In the New Testament as in the Old Testament, prayer was an attitude.

Paul recommends that we pray continually. See 1 Thessalonians 5:23. 
Handout 3

It is important to:

1. Importance of finding a time to pray.

2. A place for prayer is essential.

3. Be consistent. This is the secret of a victorious spiritual life.

4. Seek for solitude. Make this time for companionship with God.

5. Learn to be specific.

6. Determine to focus on God, not on yourself.

7. Assimilate God's will.

8. Make a routine to listen to God's will.

9. Repeat Bible prayers.

10.Make it a habit to pray continually.

\section{Seminar on Personal Bible Study}

Instructor: Julio Juárez

Phone: (708) 484-5170

Email:

\section{SEMINAR DESCRIPTION}

This course intends to provide to the participants the necessary tools for beginning and maintaining a program of personal daily Bible study.

II. METHODS OF INSTRUCTION

Subject areas from description outline will be addressed through lectures, group discussion, transparencies, and slides.

III. GENERAL OBJECTIVE

Participants will be able to understand the role of personal Bible study in their devotional lives.

IV. SPECIFIC GOALS

1. They will be able to plan a strategy for personal Bible study.

2. They will be able to comprehend the importance of having a daily schedule.

3. They will be able to incorporate mental Bible icons during the day. 


\section{OUTLINE OF THE COURSE}

Review of the selected portion of the Bible for study in:

A. The Old Testament

B. The New Testament

Analysis of Hebrew and Greek terms:

A. Hebrew Terms, Old Testament

B. Greek Terms, New Testament

Planning a Strategy for a Personal Daily Bible Study Program

1. Importance of choosing a place.

2. Deciding how long to spend each day.

3. Praying before the start of personal study.

4. Importance of selecting a Bible portion for daily study.

5. Think iconographically.

6. Learn to listen to God's voice.

7. Pray when you conclude it.

\section{REQUIREMENTS}

There are no excuses for participants if they missed a session.

Participation is important both in group discussion and during the lectures.

It is important to read extra materials and handouts.

\section{BIBLIOGRAPHY}

Foster, Richard J. Celebration of Discipline: The Path to Spiritual Growth. San Francisco: Harper Collins Pub., 1078. Pages 62-76.

Mulholland, Bob. Shaped by the Word. Nashville: The Upper Room, 1985.

Saaman, Philip. Christ's Way to Spiritual Growth. Hagerstown, MD: Review and Herald Pub. Assn., 1995. Pages 141-167.

White, Ellen G. Education. Mountainview, CA: Pacific Press Pub. Assn., 1956. Pages 119-185.

White, Ellen G. Consejos para Padres y Maestros. Mountainview, CA: Pacific Press Publishing Assn., 1956. Pages 407-451. 


\section{Handout 1}

The word study is not found in the Old Testament.

The word for study in the Old Testament is הגה which means "meditate, ruminate, recite, whisper."

For the Hebrews of the Old Testament meditation was an act of concentrating on God.

The Israelites kept the echoes of the word of God in their minds all the time.

To meditate on God's word was to understand everything from God's perspective.

They read his word every day. Joshua 1:8.

His word would convert them. Psalm 19:7.

If they read His word, it would make them wise. Psalm 19:7.

\section{Handout 2}

In the New Testament the word $\varepsilon \rho \alpha v v \alpha \omega$ is used to refer to a person who investigates a case.

Christ urged his hearers to carefully study the scriptures. John 5:39.

The Bereans were an example to all Christians in their aproach to the study of scriptures.

The study of scriptures kept Jesus from the dominion of satan. Matthew 4:4.

Paul asked Timothy to bring the scroll to the jail. It was the only way he could find spiritual strength by reading the word.

Christ always answered his opponents with a quotation from the Old Testament.

\section{Handout 3}

It is important to:

1. Importance of choosing a place.

2. Deciding how long to spend each day.

3. Praying before the start of personal study.

4. Importance of selecting a Bible portion for daily study.

5. Think iconographically.

6. Learn to listen to God's voice. 
7. Pray when you conclude it. 


\section{BIBLIOGRAPHY}

"Acts." Seventh-day Adventist Bible Commentary. Edited by F.D. Nichol. Boise, ID: Pacific Press, 1988. 6:340.

The Analytic Greek Lexicon. Grand Rapids, MI: Zondervan Pub. House, 1973.

Anders, Max. 30 Days to Understand The Bible in 15 Minutes a Day. Nashville: Thomas Nelson Pub., 1988.

Arndt, William F., and Wilbur Gingrich. A Greek English Lexicon of the New Testament and Other Early Christian Literature. Chicago: University of Chicago Press, 1957.

Argueta, Daisy. Interview by author, 6 September 1997, Chicago, IL.

Bakers, Steve. Good Things Come in Small Groups. Downers Grove, IL: Intervarsity Press, 1985.

Barclay, William. The Gospel of Luke. Philadelphia: Westminster Press, 1975.

. The Gospel of Matthew. 2 vols. Philadelphia: Westminster Press, 1977.

. The Gospel of John. 2 vols. Philadelphia: Westminster Press, 1975.

. The Letters to the Philippians, Colossians and Thessalonians. Philadelphia: Westminster Press, 1975.

Press, 1975.

.The Letters to Timothy, Titus, and Philemon. Philadelphia: Westminster

Barth, Karl. Prayer. Philadelphia: Westminster Press, 1949.

Birnbaum, Philip. A Book of Jewish Concepts. New York: Hebrew Pub. Co., 1975.

Blaiklock, M. E. "Berean." The Zondervan Pictorial Encyclopedia of the Bible. Edited by Merill Tenney. Grand Rapids, MI: Zondervan Pub. House, 1976. 1:524.

Bloesch, Donald. The Struggle of Prayer. San Francisco: Harper \& Row Pub., 1980. 
Bosch, David. Transforming Mission Paradigm Shift in Theology of Mission. New York: Orbis Books, 1995.

Bruce, F. New Testament Development of the Old Testament Themes. Grand Rapids, MI: Wm. B. Eerdmann's Pub. Co., 1968.

Brueggmann, Walter. The Psalms: The Life of Faith. Minneapolis: Fortress Press, 1979.

Bultmann, Rudolf. Theology of the New Testament. Salamanca, Spain: Ediciones Sígueme, 1978.

Carlson, Raymond. Preparing to Teach God's Word. Springfield, MO: Gospel Pub. House, 1975.

Cattel, Everett L. The Spirit of Holiness. Grand Rapids, MI: Wm. B. Eerdmann's Pub. Co., 1963.

Chanagá, Jaime. Interview by author, 12 October 1997, Chicago.

Childs, Brevard S. "Interpreting the Bible amid Cultural Changes." Theology Today 45, no. 2 (July 1997): 202.

The Christian on His Knees. Barcelona, Spain: Talleres Gráficos de la M.C.E. Horeb, 1987.

Clarke, Adam G. Analytical Studies in the Book of Psalms. Grand Rapids, MI: Kregel Pub., 1979.

Cohen, Garren G. "שיר." The Theological Wordbook of the Old Testament. Edited by Laird R. Harris and Glenson L. Archer. Chicago: Moody Press, 1980. 2:875-876.

Cohen, Elizabeth. Teaching College. New York: Columbia University College Press, n.d.

Collins, Gary. Christian Counseling. Dallas: Word Pub., 1988.

Communion With God. Mountain View, CA: Pacific Press Pub. Assn., 1967.

Cullmann, Oscar. Prayer in the New Testament. Minneapolis: Fortress Press, 1995.

Cummings, Jim. Empowering Minority Students. Sacramento: California Assn. of Bilingual Ed., 1989.

Danby, Herbert, ed. The Mishna. Oxford, England: Oxford University Press, 1974. 
De Vaux, Roland. Ancient Israel: Its Life and Institutions. Philadelphia: Westminster Press, 1975.

DeBlaissie, Paul. Deep Prayer Healing For The Hurting Soul. New York: Crossroad Pub. Co., 1990.

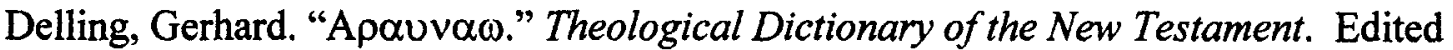
by Gerhard Kittel. Grand Rapids, MI: Wm. B. Eerdmann's Pub. Co., 1979. 2:65557.

Dewel, Wesley. Mighty Prevailing Prayers. Grand Rapids, MI: Zondervan Pub. House, 1990.

Días de León, Jesús. Course of Greek Roots. Paris, France: Libreria de la V. de Ch. Bouret, 1920.

Dodd, Brian J. Praying Jesus' Way. Downers Grove, IL: Intervarsity Press, 1967.

Dodd, Charles. The Authority of the Bible. Glasgow, England: William Collins Sons \& Co. 1960.

. The Bible Today. Cambridge, England: Cambridge University Press, 1968.

. Interpretation of the Fourth Gospel. Cambridge, England: Cambridge University Press, 1968.

Dorr, Donald. Integral Spirituality Resources for Community, Peace, Justice, and the Earth. New York: Orbis Book, 1990.

Dossey, Larry. Prayer Is Good Medicine. San Francisco: Harper Collins Pub., 1996.

Drakeford, John. Experience Bible Study. Nashville: Broadman Press, 1974.

Drijves, Pious. The Psalms: Their Structure and Meaning. Montreal, Canada: Palm Pub., 1979.

Duewel, Wesley L. Mighty Prevailing Prayer. Grand Rapids, MI: Zondervan Pub. House, 1990.

Dyrness, William. Themes in the Old Testament Theology. Downers Grove, IL: Intervarsity Press, 1971.

Eliff, Tom. A Passion for Prayer. Wheaton, IL: Crossway Books, 1998. 
Ellis, Early. Paul's Use of the Old Testament. Grand Rapids, MI: Baker Book House, 1981.

Ellul, Jacques. Prayer and Modern Man. New York: Seabury Press, 1970.

Engelkemier, Joe. 30 Days to a More Powerful Life. Nampa, ID: Pacific Press Pub. Assn., 1998.

.Whatever It Takes Praying: How Our Yes to What God Asks Brings His Yes to What We Ask. Fallbrook, CA: Hart Research Center, 1993.

Fact Book Chicago Metropolitan Area 1990. Chicago: Academy of Chicago Pub., 1995.

Fisher, Fred L. Prayer in the New Testament. Philadephia: Westminister Press, 1952.

Foster, Richard. Celebration of Discipline: The Path to Spiritual Growth. San Francisco: Harper Collins Pub., 1978.

. Prayer: Finding the Heart's True Home. San Francisco: Harper Collins Pub., 1992.

Foster, Richard, and James B. Smith. Devotional Classics. San Francisco: Harper Collins Pub., 1989.

Funderburk, Guy. "Meditation." The Zondervan Pictorial Encyclopedia of the Bible. Edited by Merill Tenney. Grand Rapids, MI: Zondervan Pub. House, 1976. 4:163.

Galloway, Dale. 20/20 Vision: How to Create a Successful Church with Lay Pastors and Cell Groups. Portland, OR: Scott Pub. Co., 1998.

García Cordero, Maximiliano. Theology of the Bible. Madrid, Spain: Ediciones Católica S.A., 1970.

Giacumakis, George, Jr. "Desert." The Zondervan Pictorial Encyclopedia of the Bible. Edited by Merill Tenney. Grand Rapids, MI: Zondervan Pub. House, 1976. 2:1067.

Gomez, Peter. "Pilgrims for Spirituality." U.S. News and World Report, 23 December, 1996, 80.

Greenlee, Harold J. A Concise Exegetical Grammar of the New Testament. Grand Rapids, MI: Wm. B. Eerdmann's Pub. Co., 1979 


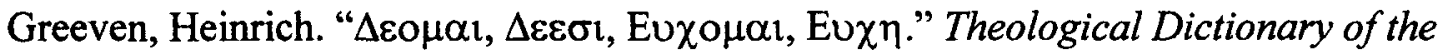
New Testament. Edited by Gerhard Kittel. Grand Rapids, MI: Wm. B. Eerdmann's Pub. Co., 1979. 2:775-784, 41-42.

Grumlan, Stephan. "How Do We Measure Up 'Measuring Up.'” Ministry 71, no. 11 (November 1998): 16-17.

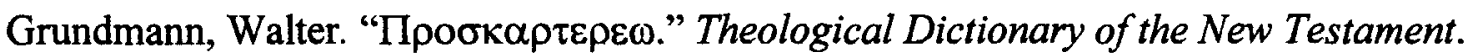
Edited by Gerhard Kittel. Grand Rapids, MI: Wm. B. Eerdmann's Pub. Co., 1979. 4:618.

Hall, Dudley. Incense and Thunder: Experience Intimacy and Power with God through Prayer. Sisters, OR: Multnomah Pub., 1999.

Hamilton, Victor P. "פליל." Theological Wordbook of the Old Testament. Edited by Laird R. Harris and Glenson L. Archer. Chicago: Moody Press, 1982. 2:725-26.

Hamman, A. Prayer in the New Testament. Chicago: Franciscan Herald Press, 1971.

Hanson, A. T., and R. C. Hanson. The Bible Without Illusions. Philadelphia: Trinity Press International, 1999.

Harkness, Georgia. Religious Living. New York: Association Press, 1992.

Hartley, John F. "הגה." Theological Wordbook of the Old Testament. Edited by Laird R. Harris and Glenson L. Archer. Chicago: Moody Press, 1980. 1:403-408.

Heschel, Abraham. The Insecurity of Freedom. San Francisco: Harper \& Bros., 1950. 1966. . Moral Grandeur and Spiritual Audacity. New York: Farrar Straus Giroux, . "On Prayer." Conservative Judaism 25, no. 1 (Fall 1970): 84-101.

Hoge, Dean R., Benton Johnson, and Donald A. Luidens. Vanishing Boundaries: The Religion of Mainline Protestant Baby Boomers. Louisville: Westminister/John Knox Press, 1994.

Hull, Bill. The Disciple-Making Pastor. Grand Rapids, MI: Baker Book House, 1984.

Humboldt Park Hispanic Church. Membership Book Records, 1997. . Membership Book Records 3rd quarter, 1997. 
Membership Clerk Records $4^{\text {th }}$ quarter, 1998.

. Membership Directory, 1996.

. Membership Directory, 1997.

. Treasury Report, December 1997.

Hunter, Bingham. God Who Hears. Downers Grove, IL: Intervarsity Press, 1986.

Hunter, George. How to Reach Secular People. Nashville: Abingdon Press, 1992.

Hunter, Kent R. Moving the Church into Action. St. Louis, MO: Concordia Pub. House, 1989.

Illinois Conference of Seventh-day Adventists. Baptisms, Updated Records. Brookfield, IL, 1982.

. Directory. Brookfield, IL; 1983.

. Treasury Report. Brookfield, IL; 1997.

Jacobs, Louis. The Jewish Religion Companion. Oxford, England: University Press, 1995.

Jeremias, Joachim. The Prayers of Jesus. Philadelphia: Fortress Press, 1978. 1985. .Theology of the New Testament. Salamanca, Spain: Ediciones Sigueme,

Johnson, Douglas. Empowering the Volunteers. Nashville: Abingdon Press, 1991.

Johnson, Bell. To Will God's Will. Philadelphia: Westminster Press, 1987.

Josephus, Flavio. Antiquities: The Bible Library. [CD-ROM]. Oklahoma City, OK: Pub. Desktop Databases, 1988.

Keiper, Ralph. The Power of Biblical Thinking. Old Tappan, NJ: Fleming H. Revel Co., 1958.

Kempis, Thomas. The Imitation of Christ. Garden City, NY: Image Books, 1955.

The Kneeling Christian. Barcelona, Spain: Talleres Gráficos de la M.C.E. Horeb, 1987. 
Koening, John. Rediscovering the New Testament Prayer. San Francisco: Harper Collins Pub., 1971.

Kraus, Hans J. Theology of the Psalms. Salamanca, Spain: Ediciones Salamanca, 1979.

Ladd, George. A Theology of the New Testament. Grand Rapids, MI: Wm. B. Eerdmann's Pub. Co., 1974.

Lall, Bernard M. Heaven's Unlimited Power at Our Disposal. Berrien Springs, MI: Geetanjaly Pub., 1987.

LaRondelle, Hans. Deliverance in the Psalms. Washington, DC: Review and Herald Pub. Assn., 1983.

Lechman, Judith. The Spirituality of Gentleness: Growing Toward Christian Wholeness. San Francisco: Harper \& Row Pub., 1987.

Lemaire, André. "Education." The Anchor Bible Dictionary. New York: Doubleday, 1992. 2:301-312.

Levin, Etan. A Jew Reads the New Testament. Madrid, Spain: Ediciones Cristiandad, 1980.

Lienhard, Joseph. The Bible, the Church and Authority. Collegeville, MN: Liturgical Press, 1995.

Luther, Martin. Quoted in Karl Barth, Prayer. Philadelphia: Westminster Press, 1949. Quoted in Richard Foster and James B. Smith, eds., Devotional Classics: Selected Readings for Individuals \& Groups. San Francisco: Harper Collin Pub., 1989.

Lyotard, Jean F. "Defining the Post-Modern." In The Cultural Studies Reader, ed. Simon During, 170-177. New York: Routledge, 1993.

MacDonald, William G. Greek Enchridion: A Concise Handbook of Grammar for Translation and Exegesis. Peabody, MA: Hendrickson Pub., 1995.

MacCall, Will. "Empty Churches or Ministry Centers." Ministry 23, no. 1 (January 1997): 23-26.

MacKibben, Jorge F. Greek-Spanish Lexicon of the New Testament. Buenos Aires, Argentina: Casa Bautista de Publicaciones, 1970. 
Macquitty, Miranda. Desert. New York: Alfred A. Knopf, 1994.

Martinez, José. Job: Faith in Conflict. Madrid, Spain: Viasa I. G. Dr. Moragas y Barret., 1973.

Mastrapa, Oliver. Interview by author, 9 September 1997, Chicago, Il.

"Matthew." Seventh-day Adventist Commentary, Edited by Francis D. Nichol. Washington, DC: Review \& Herald Pub. Assn. 1953-57. 5:303.

Maxwell, John. Partners in Prayer. Nashville: Thomas Nelson Pub., 1996.

Maxwell, Randy. If My People Would Pray. Miami: Asosiación Publicadora Interamericana, 1977.

Mayhall, Carole. Come Walk With Me. Colorado Springs, CO: Water Book Press, 1992.

Millard, Erickson J. Readings in Christian Theology: The Living God. Grand Rapids, MI: Baker House Book, 1973, Vol. 1.

Miller, Calvin, and Derek Morris. "A Marketplace Preaching: An Interview With Calvin Miller." Ministry 71 (November 1998): 13-14.

Molina, Cornelio. Interview by author, 3 October 1998.

Moorehead, Bob. The Growth Factor. Joplin, MO: College Press Pub. Co., 1991.

Morneau, Roger J. The Incredible Power of Prayer. Washington, DC: Review And Herald Pub. Assn., 1997.

Morris, Henry. Explore the Word! San Diego: Creation-Life Pub., 1978.

Morris Meaghan. "Things to Do with Shopping Centers." In The Cultural Studies Reader, ed. Simon During, 295-319. New York: Routledge, 1993. 295-319.

Mulholland, Robert M. Shaped by the Word. Nashville: The Upper Room, 1985.

Murray, Andrew. Abide in Christ. Springfield, PA: Whitaker House, 1976.

. The Inner Life. Springfield, PA: Whitaker House, 1984.

. In Search of Spiritual Excellence: Discover Power-Filled Living.

Springdale, PA: Whitaker House, 1984. 
Negoita, A. "הגה." Theological Dictionary of the Old Testament. Edited by Johannes G. Botterweck and Helmer Ringgren. Grand Rapids, MI: William B. Eerdmann's Pub. Co., 1990. 3:321-324.

Neusner, Jacob. What Is Midrash? Philadelphia: Fortress Press, 1987.

Newman, Barclay, Jr. A Greek Concise Greek-English Dictionary of the New Testament. London, England: United Bible Society, 1971.

Ortiz, Sergio. Interview by author, 2 August 1997, La Sierra, CA.

Pabón, José M. Manual Greek-Spanish Dictionary. Barcelona, Spain: Bibliografia Departamento Editorial, 1973.

Philo. De Sacrificiis. Quoted in Etan Levin. A Jew Reads the New Testament. Madrid, Spain: Ediciones Cristiandad, 1980.

Perschbacher, Wesley J. Refresh Your Greek: Practical Helps for Reading the New Testament. Chicago: Moody Press, 1980.

Peters, Hugo M. The New Greek-Spanish New Testament Concordance. Buenos Aires, Argentina: Editorial Nuevo Mundo, 1976.

Piñero, Felipe. Interview by author, 10 September 1997, Chicago, IL. . Interview by author, 5 October 1997, Chicago.

Pipin, Samuel K. Receiving the Word. Berrien Springs, MI: Berean Books, 1996.

"Psalms," Seventh-day Adventist Bible Commentary. Edited by Francis D. Nichol. Washington, DC: Review and Herald Pub. Assn., 1953-57. 3:941.

Quiñónez, Ramón. Interview by author, 5 October 1997, Chicago.

Ramírez, Lorenzo. Interview by author, 8 October 1997, Chicago.

Ramm, Bernard. Special Revelation and the Word of God. Grand Rapids, MI: Wm. B. Eerdmann's Pub. Co., 1967.

Rey Suárez, Alderman of $31^{\text {st }}$ ward Chicago. Interview by author, 6 October 1997, Chicago.

Robertson, A.T. and Hersey W. Davis. A Short Grammar of the New Testament. Grand Rapids, MI: Baker Book House, 1989. 
Russell, Dorothy. "An Analysis of Development Theory and Invitational Education." In Advance Invitation Thinking, ed. John Novak, 159-192. San Francisco: Caddo Gap Press, 1992.

Sahlin, Monte. Survey. Takoma Park, MD: General Conference of Seventh-day Adventists, North American Division. Manuscript, in my possession.

Samaan, Philip. Christ's Way to Spiritual Growth. Hagerstown, MD: Review And Herald Pub. Assn., 1995.

Schreiter, Roberto J. Constructing the Local Theologies. London: SCN Press, 1985.

Secretary of the Illinois Conference of SDAs. Updated Membership Records, 1998.

Seybold, Kiel. "חלה." Theological Dictionary of the Old Testament. Edited by Johannes G. Botterweck and Helmer Ringgren. Grand Rapids, MI: Wm. B. Eerdmann's Pub. Co., 1990. 4:399-409.

Shulman, Albert. Gateway to Judaism Encyclopedia Home Reference. New York: Thomas Yosetoff, 1971.

Smith, James B. A Spiritual Formation Wordbook. San Francisco: Harper Collins Pub., 1993.

The Source Book Zip Code. $13^{\text {th }}$ ed. Omaha, NE: American Business Information, 1979.

Sproul, R. C. Knowing Scriptures. Downers Grove, IL: Intervarsity Press, 1979.

Spurgeon, Charles. Quoted in Dwight Nelson, Power of Prayer. N.p., n.d.

Standard Desk Dictionary. New York: Funk \& Wagnall's Pub. Co., 1974.

Stenbron, Melvin J. Can a Pastor Do It Alone? Ventura, CA: Regal Book, 1987.

Steere, Douglas. Dimensions of Prayer: Cultivating a Relationship with God. Nashville: Upper Room Books, 1967.

Strobel, Lee. Inside the Mind of Unchurched Harry \& Mary. Grand Rapids, MI: Zondervan Pub. House, 1993.

Temple, Todd. 21 Days to Enjoying Your Bible. Grand Rapids, MI: Zondervan Pub. House, 1998. 
Thurston, Bonnie. Spiritual Life in the Early Church. Augsburg, MN: Fortress Press, 1993.

Tillich, Paul. Quoted in John Maxwell, Partners in Prayer. Nashville: Thomas Nelson Pub., 1996.

Troeger, Thomas H. Rage! Reflect. Rejoice! Philadephia: Westminster Press, 1973.

Ulanov, Ann, and Barry Ulanov. Primary Speech: A Psychology of Prayer. Atlanta: John Knox Press, 1993.

Underhill, Evelyn. Quoted in Richard Foster and James B. Smith, eds., Devotional Classics. San Francisco: Harper Collins Pub., 1989.

Van Rad, Gerhard. Studies on the Old Testament. Madrid, Spain: Ediciones Sigueme, 1976.

Vásquez, Aida. Interview by author, 8 October 1997, Chicago.

Viber, Ronald. Telephone interview by author, 27 May 1999.

Walker, Williston. A History of the Christian Church. New York: Charles Scribner's Sons, n.d.

Wagner, Peter. Churches That Pray. Ventura, CA: Regal Books, 1993.

Watson, David. Called \& Committed: World-Changing Discipleship. Wheaton, IL: Harold Shaw Pub., 1982.

Watts, Dorothy E. Prayer Treasures: Discover the Riches of Prayer. Boise, ID: Pacific Press Pub. Assn., 1995.

Weber, Carl P. "הלה." In Theological Wordbook of the Old Testament. Edited by Laird R. Harris and Glenson L. Archer. Chicago: Moody Press, 1981. 1:656.

Weber, Hans R. The Bible Comes Alive: New Approaches for Study Groups. Valley Forge, PA: Judson Press, 1996.

Churches, 1978.

. Experiments with Bible Studies. Geneva, Switzerland: World Council of

Wells, David. No Place for Truth, or Whatever Happened to Evangelical Theology? Grand Rapids, MI: Wm. B. Eerdmann's Pub. Co., 1993. 
Werbowski, Zwi. The Encyclopedia of the Jewish Religion. New York: Holt, Reinhardt and Winston, 1996.

White, Arthur L. Ellen G. White. Vol. 3, The Lonely Years, 1876-1891. Washington, DC: Review \& Herald, 1981-1986.

Ellen G. "Better Counsels to Parents." Ellen G. White Research Center, Andrews University, Berrien Springs, MI.

. "The Bible As a Text." Testimony For the Battle Creek Church, Ellen G.

White Research Center, Andrews University, Berrien Springs, MI.

PR 12.

. "The Book of Books." Advent Review and Sabbath Herald, 21 August, 1891,

. "Cease from Idolatry." Advent Review and Sabbath Herald, 2 June 1891, PR 12.

. Child Guidance. Mountain View, CA: Pacific Press Pub. House Assn.,1956.

. "Christ, the Medium of Blessings." Signs of the Times, 18 June 1896, PR 8.

. Counsels to Parents, Teachers, and Students. Harrak, OK: Academic

Enterprises Inc., 1975.

. Desire of Ages. Mountain View, CA: Pacific Press Pub. Assn., 1956.

. "Diligent and Thorough Special Education." Testimonies for Education.

Ellen G. White Research Center, Andrews University, Berrien Springs, MI.

. Education. Mountain View, CA: Pacific Press Pub. House Assn. 1923.

. Fundamentals of Christian Education. Mountain View, CA: Pacific Press

Pub. Assn., 1923.

. "The Importance of Bible Study." The Watchman, 12 September, 1905, PR 2.

. In Heavenly Places. Nampa, ID: Pacific Press Pub. Assn., 1970.

. "The Judgment." Ellen G. White Research Center, Andrews University, Berrien Springs, MI.

. "Letter to Elder Daniels and His Fellow-Workers." Letter 49, 1903. Ellen G. White Research Center, Andrews University, Berrien Springs, MI. 

1956.

. Messages to Young People. Mountain View, CA: Pacific Press Pub. Assn., . Mind, Personality, and Character. 2 volumes. Mountain View, CA: Pacific Press Pub. Assn.. 1956.

The Ministry of Healing. Mountain View, CA: Pacific Press Pub. Assn., 1956.

. "Our Need of the Holy Spirit." Advent Review and Sabbath Herald, 3 January 1907, PR 3.

. "Peter's Counsel to Parents." Ellen G. White Research Center, Andrews University, Berrien Springs, MI.

. Prophets and Kings. Mountain View, CA: Pacific Press Pub. Assn., 1943. 1958.

Selected Messages. Vol. 1. Mountain View, CA: Pacific Press Pub. Assn., . Special Testimonies for Ministers and Workers. Ellen G. White Research Center, Andrews University, Berrien Springs, MI.

. Steps to Christ. Washington, DC: Review and Herald Pub. Assn., 1977.

Testimonies for the Church. 9 volumes. Mountain View, CA: Pacific Press Pub. Assn., 1948.

Testimonies on Sabbath School Work. Mountain View, CA: Pacific Press Pub. Assn., 1956.

. This Day With God. Mountain View, CA: Pacific Press Pub. Assn., 1970.

Thoughts from the Mount of Blessings. Mountain View, CA: Pacific Press Pub. Assn., 1955. 1893,7 .

"The Weapons Against Satan's Delusions." Signs of the Times, 18 September

Wilson, William. Wilson's Old Testament Word Studies. MacLean, CA: MacDonald Pub. Co., n.d.

Wolf, Herbert. "חלהת." Theological Wordbook of the Old Testament. Edited by Laird R. Harris and Glenson L. Archer. Chicago: Moody Press, 1981. 1:287. 
Wright, Christopher J. Walking in the Ways of the Lord: The Ethical Authority of the Old Testament. Downers Grove, IL: Intervarsity Press, 1995.

Young, Robert. Analytical Concordance of the Bible. Peabody, MA: Hendrickson Pub., n.d. 


\section{VITA}

Name: Julio Israel Juárez.

Place of Birth: Totnicapán Guatemala, Central America.

Wife: Antonia Juárez.

Ordination: August 6, 1983, El Progreso SDA High School, Guatemala City, Guatemala. EDUCATIONAL EXPERIENCE

1957- 62 Tipo Federación Primary School Certificate, Totonicapán, Guatemala.

1974 SDA Central America Institute High School Certificate - Alajuela, Costa Rica.

1978 Ministerial Diploma - Adventist Center for Advanced Studies, Alajuela, Costa Rica.

1985 Master of Arts - Andrews University, Berrien Springs, MI.

1987,89,98 Square Supervisor - AU Summer Archaological Dig in Jordan

2000 Doctor of Ministry - Andrews University Seventh-day Adventist Theological Seminary, Berrien Springs, MI.

\section{PROFESSIONAL EXPERIENCE}

1979-1983 SDA Pastor - Guatemala Mission.

1983-1986 Church Ministry Leader- SDA Guatemala Mission.

1986-87 Theology Teacher - SDA University, Alajuela, Costa Rica.

1988-1990 Chairman of Theology School - SDA University, Alajuela, Costa Rica.

1991 SDA Field President - Honduras.

1991-1996 Elementary Teacher — District \#99 Cicero, IL. U.S.A.

1996-1999 SDA Pastor-Illinois Conference in Chicago. 